\title{
California Agriculture
}
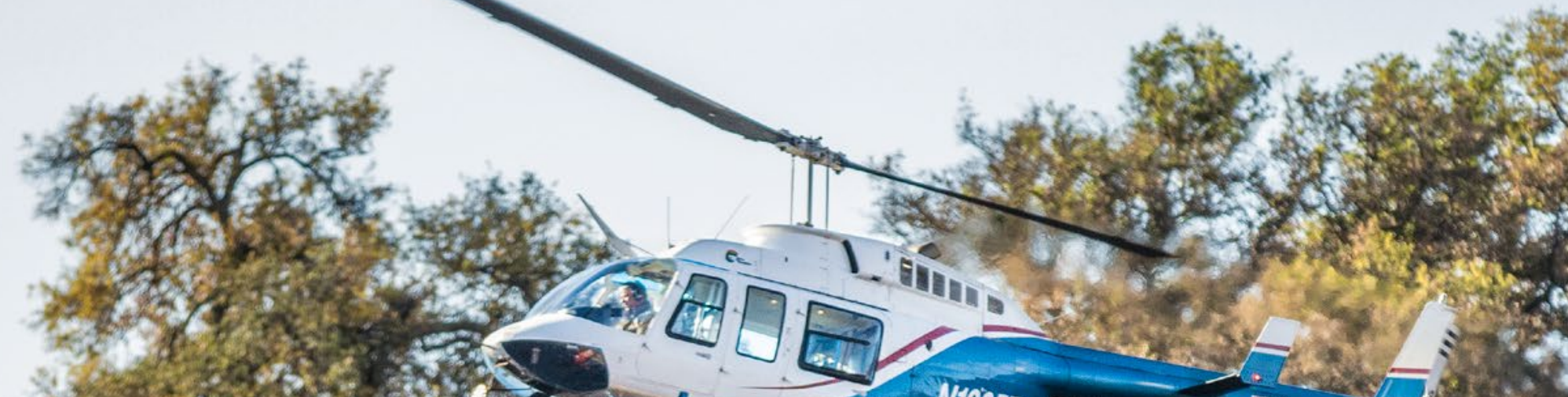

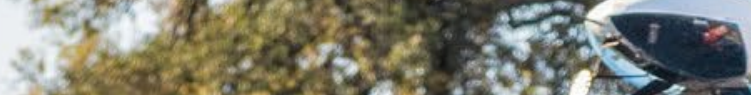

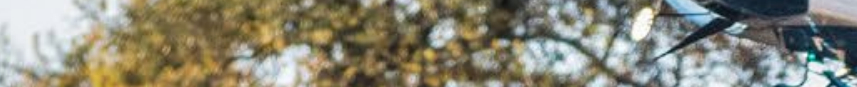

Rangeland recovery after wildfire $p 52$

Understanding Sierra Nevada

tree mortality p55

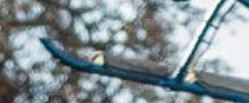

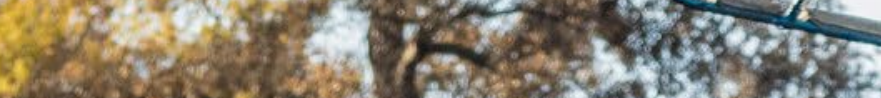

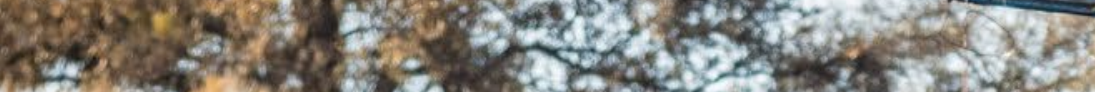
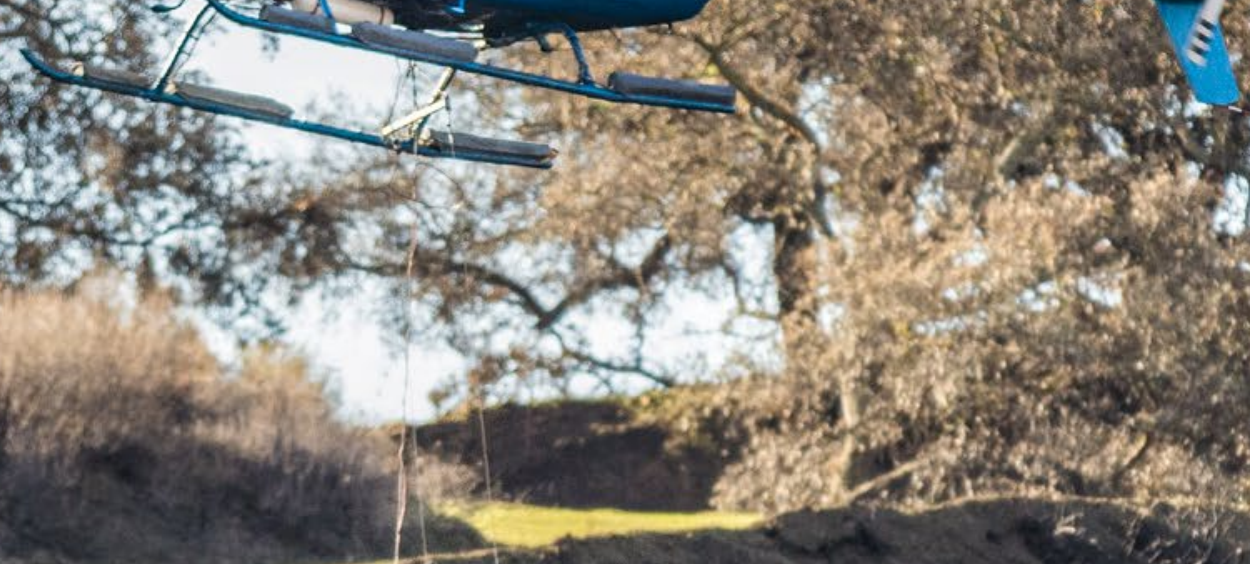

\section{California's farm labor workforce p73}

Cover crops and soil nitrogen p79

\section{Carbon dioxide removal strategies pâ9}
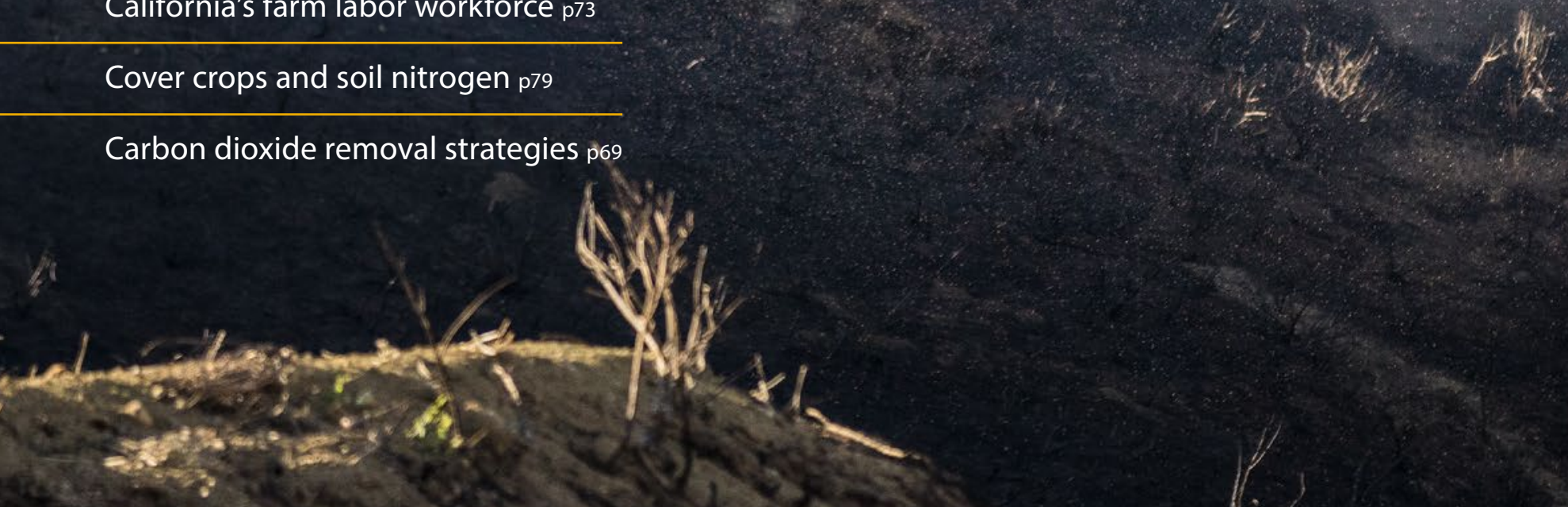


\section{California Agriculture}

Peer-reviewed research and news published by University of California Agriculture and Natural Resources

Director of Publishing, Executive Editor: Jim Downing

Managing Editor: Deborah Thompson

Senior Editor: Hazel White

Senior Writer and Editor: Lucien Crowder

Art Director: Will Suckow

\section{ASSOCIATE EDITORS}

Animal, Avian, Aquaculture \& Veterinary Sciences: John Angelos, Maurice Pitesky

Economics \& Public Policy: Rachael Goodhue, Julie Guthman Mark Lubell, Kurt Schwabe

Food \& Nutrition: Amy Block Joy, Lorrene Ritchie Human \& Community Development: Rob Bennaton, Martin Smith

Land, Air \& Water Sciences: Hoori Ajami, Khaled Bali, Yufang Jin, Sanjai Parikh

Natural Resources: Ted Grantham, William C. Stewart Pest Management: Kent Daane, Neil McRoberts, James Stapleton

It is the policy of the (UC) and the UC Division ure and Natura Resources (UC ANR) not to engage in discrimination against or harassment of any person in any of its programs or activities (Complete nondiscrimination policy found at http://ucanr.edu/sites/ anrstaff/files/187680.pdf)

Inquiries regarding the University's equa employment opportunity policies may be directed to: policies may be directed to: Affirmative Action Contact and Title IX Officer, University of California, Agriculture and Natural Resources, 280 Second Street, Davis, CA 95618, (530) 750-1397. Email: titleixdiscrimination@ucanr. edu. Website: http://ucanr. edu/sites/anrstaff/Diversity/ Affirmative_Action/.

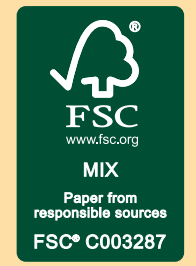

Editor's note: California Agriculture is printed on paper certified by the Forest Stewardship Council ${ }^{\bullet}$ as sourced from well-managed forests, with $10 \%$ recycled postconsumer plemental chlorine. See www. fsc.org for more information.
Plant Sciences and Agronomy: Kevin R. Day, Matthew Gilbert, Stephen Kaffka, Rachael F. Long

\section{ORDERS AND SUBSCRIPTIONS}

2801 Second Street, Room 181A; Davis, CA 95618-7779

Phone: (530) 750-1223; Fax: (530) 756-1079; calag@ucanr.edu

\section{EDITORIAL}

2801 Second Street, Room 184; Davis, CA 95618-7779

(530) 750-1223; calag.ucanr.edu

California Agriculture (ISSN 0008-0845, print, linking; ISSN 2160-8091, online) is published quarterly. Postmaster: Send change of address "Form 3579 " to California Agriculture at the address above.

(02019 The Regents of the University of California

California Agriculture is a quarterly, open-access, peerreviewed research journal. It has been published continuously since 1946 by University of California Agriculture and Natural Resources (ANR). There are about 10,000 print subscribers.

Mission and audience. California Agriculture publishes original research and news in a form accessible to an educated but non-specialist audience. In the last readership survey, $33 \%$ of subscribers worked in agriculture, $31 \%$ were university faculty or research scientists and 19\% worked in government.

Electronic version of record. In July 2011, the electronic journal (calag.ucanr.edu) became the version of record. Since then, some research article are published online only. All articles published since 1946 are freely available in the online archive, calag.ucanr.edu/Archive/.
Indexing. The journal provides article metadata to major indexing services, including Thomson (Web of Science), AGRICOLA, the Directory of Open Access Journals and EBSCO (Academic Search Complete), and has high visibility on Google Scholar. All articles are posted to eScholarship, UC's open-access repository. In the 2017 Thomson JCR, the journal's impact factor was 1.2

Authors. Most authors (75\%) are among the roughly 1,000 academics affiliated with ANR, including UC Cooperative Extension specialists, advisors and academic coordinators; and faculty in the following UC colleges: UC Berkeley College of Natural Resources, UC Davis College of Agriculture and Environmental Sciences, UC Davis School of Veterinary Medicine, and UC Riverside College of Natural and Agricultural Sciences. Submissions are welcome from researchers based at government agencies and at other campuses and research institutes.

Article submission and review. Guidelines for authors are here: calag.ucanr.edu/submitarticles/. The journal uses a double-blind peer-review process described at calag.ucanr.edu/About/. Roughly $50 \%$ of all submissions are rejected by the editors without peer review due to a mismatch with the journal's scope or clear weaknesses in the research. Of the subset of submissions that enter the peer-review process, roughly $60 \%$ are ultimately accepted. All accepted manuscripts are edited to ensure readability for a non-specialist audience.

Letters. The editorial staff welcomes letters, comments and suggestions. Please write to us at the address below, providing your contact information.

Print subscriptions. These are free within the United States and \$24 per year abroad. Go to: calag.ucanr.edu/ subscribe/ or write or call.

Permissions. Material in California Agriculture, excluding photographs, is licensed under the Creative Commons CC BY-NC-ND 4.0 license. Please credit California Agriculture, University of California, citing volume, number and page numbers. Indicate O[year] The Regents of the University of California.

To request permission to reprint a photograph published in California Agriculture, please complete the UC ANR Permissions Request Form (http://ucanr.edu/survey/ survey.cfm?surveynumber=5147). In general, photos may be reprinted for non-commercial purposes.

\section{UNIVERSITY OF CALIFORNIA}

UNIVERSITY OF CALIFORNIA Agriculture and Natural Resources 


\section{Contents}

\section{News and opinion}

\section{RESEARCH NEWS}

\section{UC ANR advisors support cattle} ranchers after wildfires

White

A free hay program was started after the Thomas fire, closed highways were opened for ranchers after the Camp fire, and UC research helped answer ranchers' questions about pasture recovery.

\section{The California Tree Mortality Data} Collection Network - Enhanced communication and collaboration among scientists and stakeholders

Axelson et al.

Critical research and dialogue are underway to understand the consequences of the massive wave of tree mortality in the Sierra Nevada.

63 To build a walled garden

Crowder

Through cooperative ventures around the state, the UC Master Gardener program brings horticultural knowledge to Californians in jails, detention centers and treatment facilities.

\section{Research highlights}

Crowder

Briefs of recent Agricultural Experiment Station and UC Cooperative Extension research papers on reforestation practices, nutritional quality of home-packed lunches, environmental impact of California sheep production, and more.

\section{OUTLOOK}

\section{UC experts can lead on carbon dioxide removal}

Sanchez

Through technology demonstration and policy engagement, UC ANR specialists, advisors and AES faculty can support California's ambitions to remove $\mathrm{CO}_{2}$ from the atmosphere.

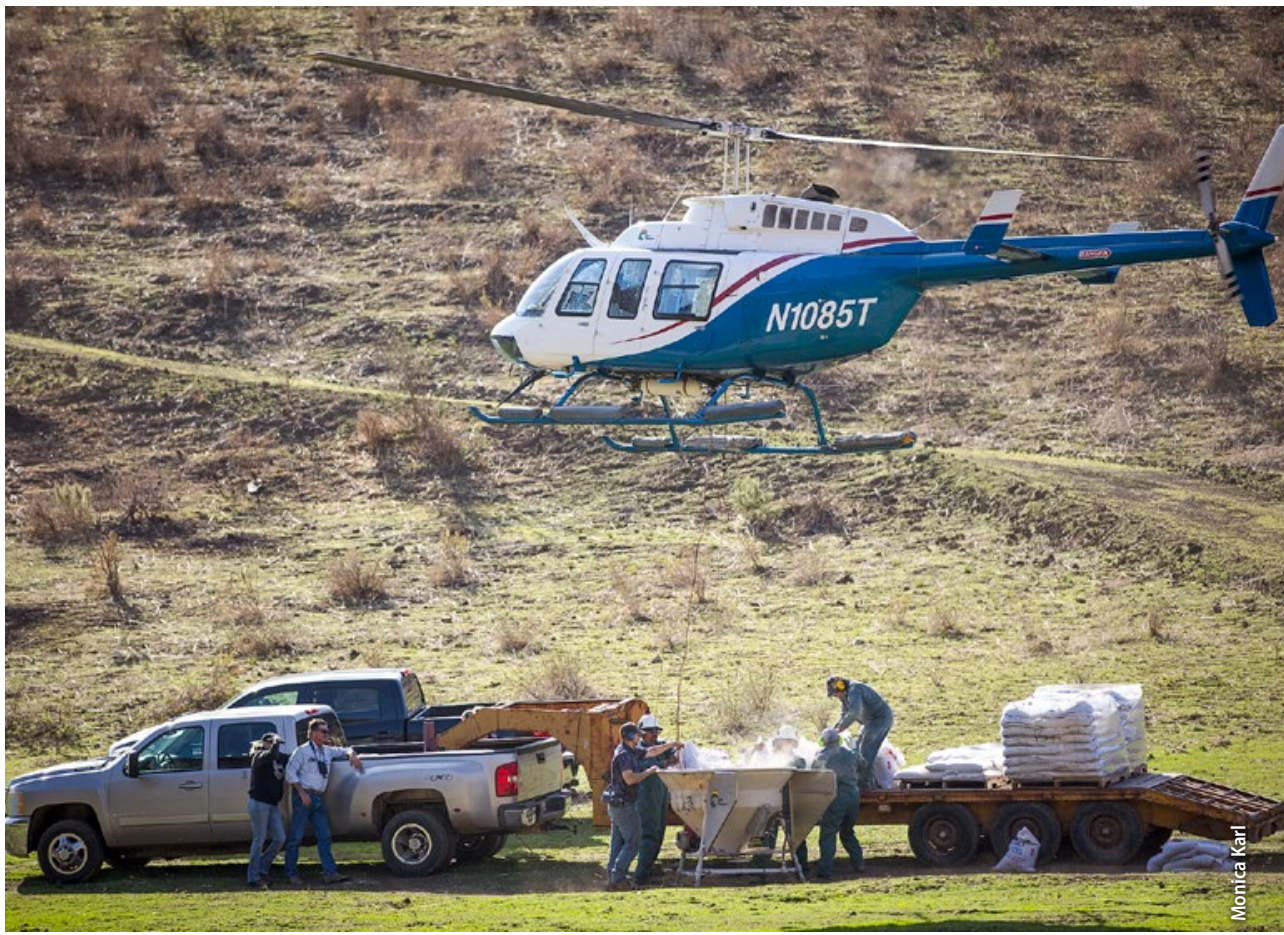

\section{Research and review articles}

73 Ratio of farmworkers to farm jobs in California increased to 2.3 in 2016

Martin et al.

The ratio of workers to average jobs is increasing, moving the farm labor market away from what public policy has long tried to achieve, a farm labor market with fewer workers who are employed most of the year.

79 Cover crops prove effective at increasing soil nitrogen for organic potato production

Wilson et al.

Organic crops command high wholesale prices, but organic management of nutrient deficiencies and pests can be a challenge.

90 Virus surveys of commercial vineyards show value of planting certified vines

Arnold et al.

In the North Coast wine-growing region, mixed infections were predominant in older vineyards, while recently planted certified vines did not have mixed infections. 


\title{
UC ANR advisors support cattle ranchers after wildfires
}

\author{
A free hay program was started after the Thomas fire, closed highways were opened for ranchers \\ after the Camp fire, and UC research helped answer ranchers' questions about pasture recovery.
}

The morning after the first day of the Thomas fire in Ventura County, around 60,000 acres of ranchland in commercial production had been burned. The first task ranchers faced was to locate cattle and find a secure place for them. Then a decision had to be made to buy hay for the winter or cull the herd.
A fter the Camp and Thomas wildfires, ranchers who had lost the annual dry grasses in the pastures that were to feed the cattle through the winter had three urgent questions. The first was an existential question - should they cull their herd. The other two concerned pasture recovery - how soon could they return cattle to burned pasture, and would the annual grasses come back well or would invasive weeds such as starthistle overwhelm the forage grasses.

UC ANR Cooperative Extension (UCCE) livestock advisors moved quickly to help ranchers after the 2018 Camp fire in Butte County and the Thomas fire in Ventura County in 2017. For example, 5 days' worth of hay was quickly provided to Ventura County ranchers to allow them a little time to strategize about what to do with their animals, and access to closed highways was negotiated for Butte County ranchers trying to move cattle. Advisors pitched all their skills and influence to provide emergency relief to affected ranchers, many of whom they knew personally. And they turned to UC research to answer the big questions.

The Camp fire occurred as ranchers in Butte County were preparing to move their cattle down from the Sierra summer pastures to the winter pastures around Paradise. In case firefighters came across cattle that had been moved there already, Butte County UCCE livestock advisor Tracy Schohr immediately put together a plan for their evacuation and transport out of the area.

Around 35,000 acres of cattle-grazing land burned in the Camp fire, and hundreds of miles of fences were destroyed, as was infrastructure such as irrigation and buildings. Ranchers had been used to a periodic fire in June or July, which gave them time to mend fences and make other repairs before the winter migration. After the November Camp fire, ranchers had to make quick decisions about where to overwinter their cattle.

Some culled their herd, some had neighbors, or friends, who could take their cattle for the winter. Some were trying to winter cattle in the summer pastures if they didn't flood. The economics of buying hay for the winter were challenging; after the fire, hay prices went up. Ranchers turned to Schohr to ask if it was safe to move their cattle to pastures near Paradise.

\section{Camp fire ash and water testing}

Schohr and Betsy Karle, the area dairy advisor, used a UC ANR opportunity grant, designed for timesensitive critical research, to assess whether it was safe for cattle to be moved onto pasture that was not burned but had received ash from the fire. They took samples of ash-covered forage from four Butte County ranches and sent them to a lab for toxicology testing. Results showed that metal concentrations were unremarkable.

Online: https://doi.org/10.3733/ca.2019a0004 


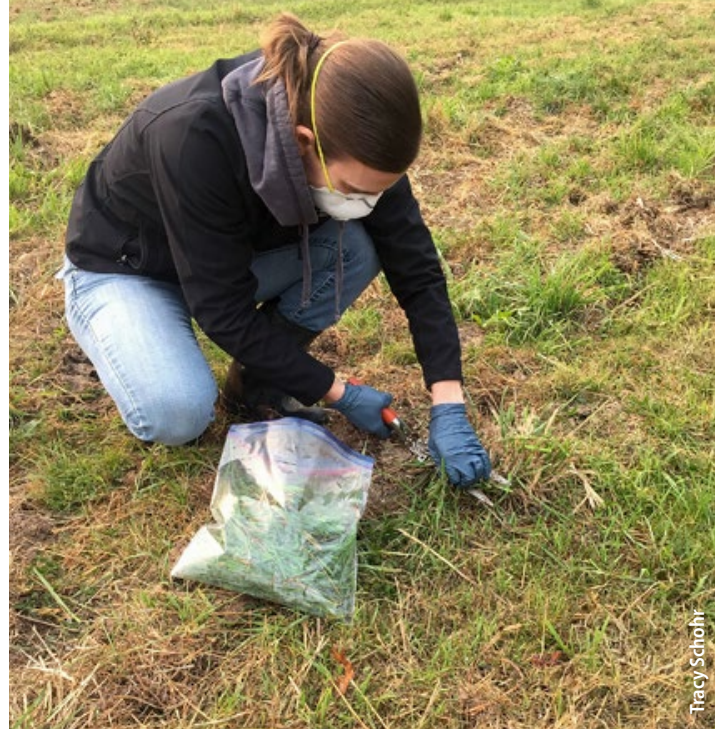

Betsy Karle, UCCE Glenn County director and area dairy advisor, takes a forage sample from a ranch in Butte County. Karle and Schohr secured a UC ANR opportunity grant to assess whether it was safe for cattle to be moved onto pasture that was not burned but had received ash from the fire.

Schohr took weekly water samples from streams in the Camp fire watershed from late November through early spring to test for the presence of heavy metals. "Nineteen thousand structures burned in the Camp fire. It was essentially an urban fire, and we don't know what contaminants could have ended up in the water," says Schohr. "The issue is a big one because Paradise is at the top of the watershed that supplies the ranchers water," she says. So far, no test results have suggested any reason for concern about heavy metals being present in the source of livestock drinking water.

\section{Weed and forage recovery}

Schohr advised ranchers that the fire would not have killed weed seeds, based on the research of Josh Davy, Tehama County livestock, range and pasture advisor and UCCE county director. Fires crossing dry pasture "move so quickly they do not produce enough soil surface heat to kill weed seeds that have fallen to the soil surface," says Davy. If the Camp fire had occurred earlier in the year, the situation may have been different: "A spring burn, while seeds are still on the plant, is very successful at controlling weeds because they are burned in the spikelet," he says. To achieve some control of returning medusahead and starthistle, Schohr recommended that burned pastures should be grazed this spring in March-April and April-June, respectively.

Davy's research suggests forage production will be greatly reduced this year on the burned pastures. In a 3-year comparison study on burned and unburned winter annual rangeland plots in Tehama County, Davy found substantial forage losses in the 2 years following the burn. "Production in the burn treatment was half that of the area not burned the following year and 79\% the second year" (Davy and Dykier 2017).

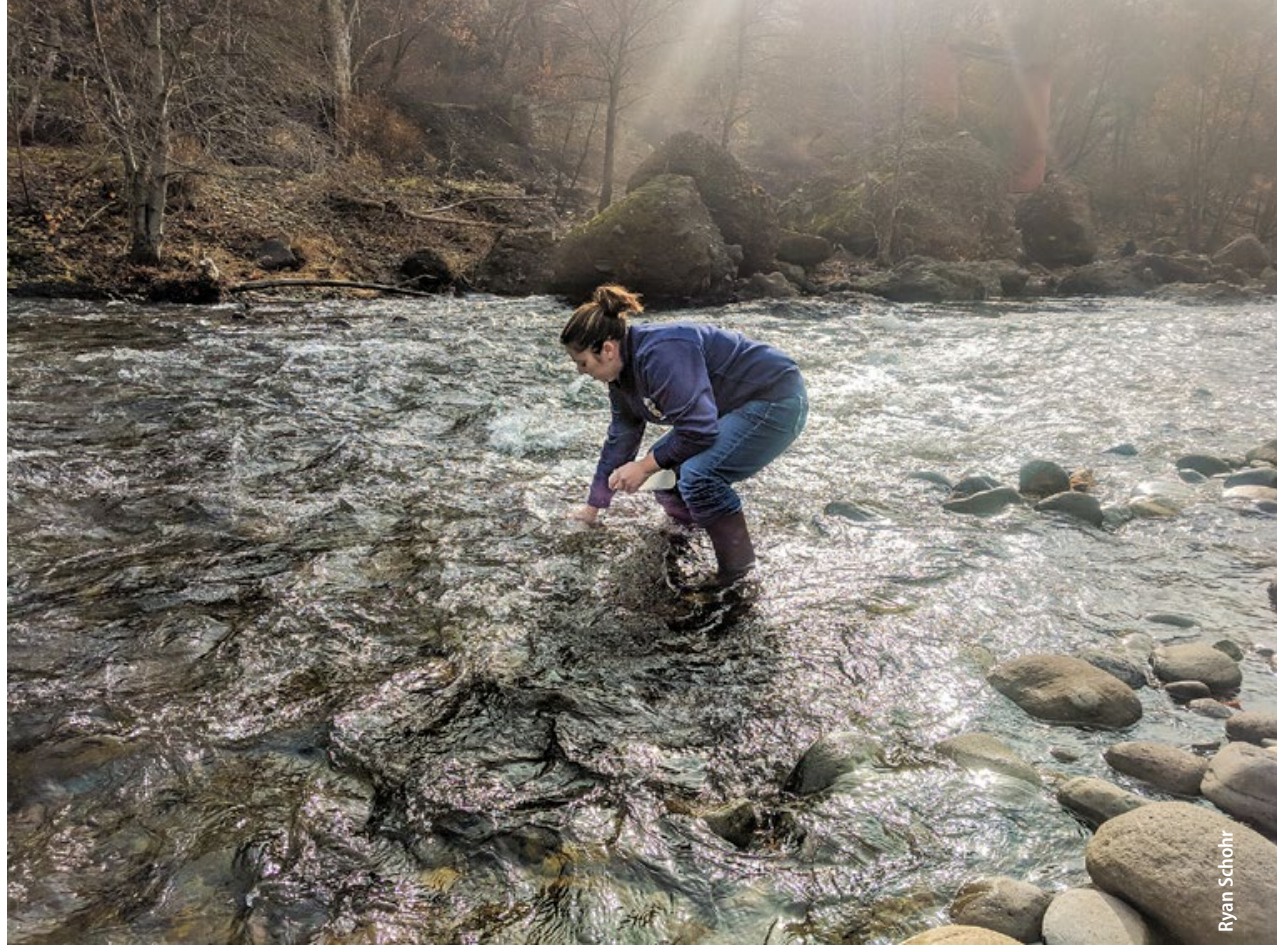

\section{Destocking, seeding options}

The toughest question ranchers had after the Camp fire, and also the Thomas fire, was whether they should sell their livestock. Though Schohr and Matthew Shapero, livestock and range advisor for Ventura and Santa Barbara counties, held meetings with ranchers on how to quickly apply for compensation with the U.S. Department of Agriculture Farm Service Agency and Natural Resources Conservation Service, any payments are usually slow to arrive. "For many ranchers, it's a real financial burden; they are on their own economically," says Shapero.

Within the first few hours of the Thomas fire, around 60,000 acres of ranches in commercial production burned. As they located missing livestock, ranchers had to find secure locations for them and decide if they were going to buy feed for the winter or destock. "Ranchers in Ventura County had just emerged from a devastating drought that had forced many of them to sell off livestock, so to sell more seemed an existential threat," says Shapero.

One option was to seed burned pasture. It would seem there would be an obvious benefit to that, but Shapero's advice was that seeding was an expensive proposition with uncertain outcomes: rains could fail and result in poor germination; birds and rodents are drawn to seeded pastures and feed on the seed; and, if rains are too heavy, seed can wash out of the soil - it's
Tracy Schohr, UCCE Butte County livestock advisor, took weekly water samples from the Feather River to check for heavy metals, which are very toxic to cattle. Paradise is at the top of the watershed that supplies water to ranchers.
Five weeks after the Camp fire started, new grass was growing on burned land. The fire left patches of unburned land (background); ranchers asked UC advisors whether it was safe to move cattle into pasture covered with ash.

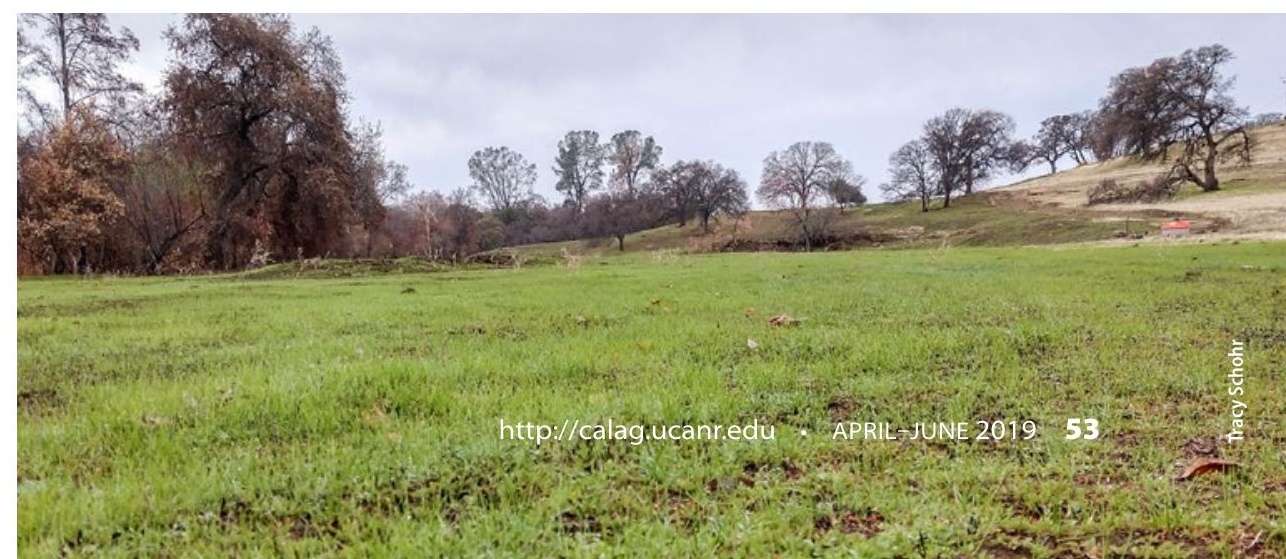




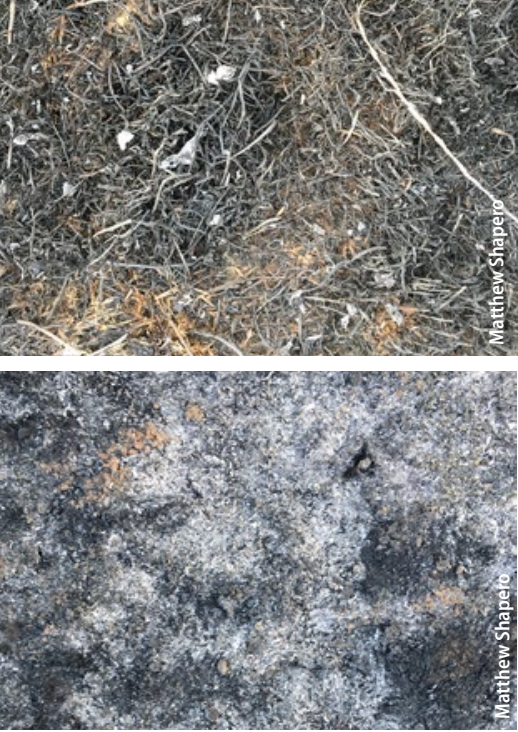

After the Thomas fire, grasslands burned at low severity, top, showed incomplete combustion and grasses were still largely present; but shrubland burned at high intensity, bottom, showed no biomass and a crusted soil surface.

Matthew Shapero, UCCE livestock and range advisor for Ventura and Santa Barbara counties, arranged for ranchers affected by the Thomas fire to receive 5 days' worth of free hay. Unknown at the time was how soon the grasslands would recover. UC studies in Tehama County showed markedly reduced pasture production in the 2 years after a burn.

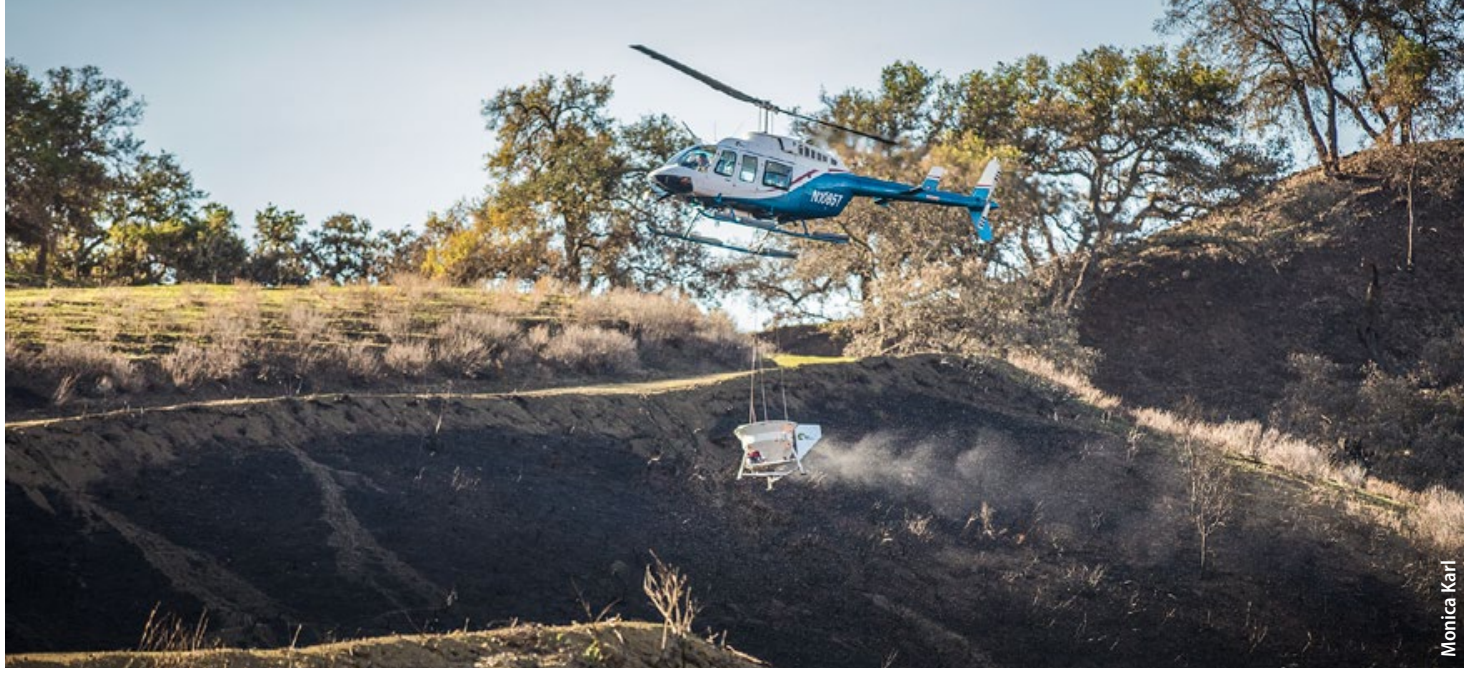

Seeding may be advantageous on badly burned land. In January 2018, 1,000 acres on this Ventura County ranch were aerially seeded with 10,000 pounds of cereal rye in 1 day. especially difficult to achieve good seed-soil contact on burned ground. Furthermore, seeding areas with nonnative forage species can be a concern for the recovery of native shrub and herbaceous species.

Research was lacking on whether seeding might be a good choice on severely burned land, where forage recovery would likely be most delayed. Shapero decided to test the viability of the forage grass seedbank in plots of unburned and burned land. On five ranches, he collected a total of 150 soil core samples from grass and shrubland areas that had experienced no burn, low-severity burn or high-severity burn and potted them up in a greenhouse and watered them, noting seed germination date and rates and function group grass, forb or shrub. Results indicated that there was no statistically significant difference in number of forage grass seedlings between no- and low-burn soil samples, but there was a significant visual difference in the number of seedlings in the high-burn soil samples. These results suggested that ranchers interested in seeding to increase post-fire forage production should target areas that experienced high-severity burning.

Davy also believes seeding could be of value in areas where fire has burned hottest, which would not usually be open grasslands, he says, but in areas with woody material. Davy has researched the best options for forage selections in Northern California foothill rangelands, in terms of their establishment and survivability over time. Of 22 diverse forages, annual ryegrass and soft brome performed well in the short term and Flecha tall fescue, several hardinggrass varieties and Berber orchardgrass worked well in the long term (Davy et al. 2017).

\section{Post-fire grazing}

One of the common questions ranchers ask after a wildfire is what effect bringing cattle back on to the land will have on forage production in the coming season. In December 2017, Shapero was awarded a UC ANR opportunity grant to research that. He placed 70 exclusion cages around 1-meter plots on the ranches to monitor post-wildfire recovery of burned land that was grazed compared to land (inside the cages) that was not. He removed the cages in May 2018 and is monitoring forage production and species composition for the next 3 to 5 years.

In December, the burned pastures around Paradise quickly produced new growth, and rains and warm temperatures in January sustained that growth. Many ranchers were letting the land rest a few months while paying for hay, but watching the land green up just weeks after the worst fire they had ever seen provided hope that recovery was underway. CA

- H. White

\section{References}

Davy J, Dykier K. 2017. Longevity of a controlled burn's impacts on species composition and biomass in Northern California annual rangeland during drought. Rangeland Ecol Manag 70:755-8

Davy J, Dykier K, Turri T, Gornish E. 2017. Forage seeding in rangelands increases production and prevents weed invasion. Calif Agr 71(4):239-48. https://doi.org/10.3733/ca.2017a0025 


\title{
The California Tree Mortality Data Collection Network - Enhanced communication and collaboration among scientists and stakeholders
}

\author{
Critical research and dialogue are underway to understand the consequences of the massive wave \\ of tree mortality in the Sierra Nevada.
}

Jodi Axelson, John Battles, Beverly Bulaon, Danny Cluck, Stella Cousins, Lauren Cox, Becky Estes, Chris Fettig, Andrea Hefty, Stacy Hishinuma, Sharon Hood, Susie Kocher, Devin McMahon, Leif Mortenson, Alexander Koltunov, Elliot Kuskulis, Adrian Poloni, Carlos Ramirez, Christina Restaino, Hugh Safford, Michèle Slaton, Sheri Smith, Carmen Tubbesing, Rebecca Wayman and Derek Young

Dead needles on tree in the Sierra National Forest.

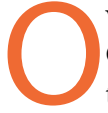

ver 147 million dead trees were detected in California by the U.S. Forest Service Aerial Detection Survey (USFS ADS) from 2010 to 2018 (USDA 2019). The massive tree mortality, mostly in the Sierra Nevada and evident in swaths of conifers with red needles, resulted from the 2012-2016 drought and subsequent explosions in native bark beetle populations. While levels of mortality have declined in the last 2 years, the consequences will last for decades to come. Trees that died will fall over and surface fuel loads will increase - already the accumulation of millions of tons of dead material on forest floors is vastly outpacing the resources of local, state and federal jurisdictions to remove it. Urgent dialogue has started among UC scientists, forest managers, and public agencies to manage the consequences of the unprecedented tree die-off and increase the resiliency of forests to future droughts.

To accomplish these goals, we need data on the rates of ongoing tree mortality and dead tree fall, surface fuel build-up, wildfire hazard, forest renewal patterns, and the course of bark beetle outbreaks. Data are also needed to understand the long-term impacts of the wave of tree mortality on ecological services such as carbon storage and water quality.
In 2017, we set up the Tree Mortality Data Collection Network, led by academics at UC Berkeley and UC Agriculture and Natural Resources, to bring together scientists and agencies who are conducting field and remote-sensing studies across the Sierra Nevada. Then, rather than waiting for the results to be published in academic journals, we decided a paradigm shift was necessary - we would translate our science into dialogue by hosting in-person events and putting the results quickly into the hands of forest decisionmakers and planners, and counties needing grants to remove accumulating surface fuels.

The dialogue began in March 2018 at the first Tree Mortality Data Collection Network workshop held at the USFS Wildland Fire Training Center in McClellan Park, Sacramento, and continued at a second workshop there in March 2019. Along with other researchers, we presented newly collected data to state and federal agencies, local governments, nongovernmental organizations, landowners and community representatives (see next pages).

\section{Online: https://doi.org/10.3733/ca.2019a0001} Published online March 11, 2019 
saplings. Ongoing monitoring will be necessary to understand these dynamics, and to inform decisions concerning how and whether, considering the changing climate, to replant underrepresented species.

\section{A rapid response framework}

Following the research updates, roundtable sessions focused on the elements of a rapid response to ongoing and future tree mortality. Ideally, a rapid response framework would be created by sharing information and coordinating decision making before a state-level emergency needed to be declared. Thresholds could be established, which when crossed would trigger specific actions across jurisdictions in a time-effective way. For example, datasets on the limited regeneration of desirable tree species, such as pines, might initiate replanting efforts focused on these species.

A rapid response framework requires collaboration in four areas: research and monitoring, land management, education and outreach, and policy. These particular needs were identified:

- a landscape-scale understanding of what factors predispose forests to mortality

- a set of key factors, or indicators, that identifies when a mortality event is occurring and where forests are most vulnerable

- tools to prevent and respond to tree mortality (e.g., streamlined permitting and adequate infrastructure such as workforce, funding and forest products processing facilities)

- projections of how tree species changes could affect ecosystem services such as water supply and quality, wildlife, aesthetics and carbon storage

- education and outreach that help the public learn what a healthy forest looks like

- across local, state and federal jurisdictions, the political will to be more proactive in forest management, especially in engaging with communities to develop collaborative planning and policy mechanisms

- indicators to identify when planting is desirable, and novel approaches to species mixes and seed zones

- guidelines on how tree density in newly regenerated areas should be maintained to be more sustainable in a changing climate

- nuanced messaging - focused on ecosystem services and wildfire hazard risk reduction - around the effects of changed species composition and the need for reforestation

- educator networks to reach all landowners, especially those in wildland-urban interface areas

- long-term, coordinated funding for forest management, perhaps from ecosystem service taxes paid by those who benefit from forests

\section{Our collective challenge}

The 2012-2016 drought in California (Swain 2015) revealed just how vulnerable vast regions of the state's forests are to extremely dry and warm conditions. In some areas the recent drought was the most severe to occur in the past 1,200 years (Griffin and Anchukaitis 2014). With more frequent and extreme drought conditions predicted with a changing climate (He et al. 2018), a better understanding of drought-induced tree mortality is essential, as are the forest management strategies that can minimize future tree mortality (Stephens et al. 2018). As the waves of red trees drop their needles and fade into the background, we hope individuals, agencies and institutions will stay engaged to promote healthy, productive and resilient forests and communities.

The degree to which we can collectively address issues raised in these workshops and develop a framework for action is ultimately contingent on securing adequate funding, continued collaboration among scientists, and continued participation by a variety of stakeholders. The Tree Mortality Data Collection Network is a first step in this direction. We will continue to share data and work with land managers and decision-makers to feed research findings into action for resilient future forests. CA

J. Axelson is Assistant Cooperative Extension Specialist, J. Battles is Professor, L. Cox and C. Tubbesing are Ph.D. Candidates, and E. Kuskulis is Pre-doctoral Fellow, Department of Environmental Science, Policy and Management, UC Berkeley; B. Bulaon is Southern Sierra Entomologist, D. Cluck is Northeastern Entomologist, A. Hefty and S. Hishinuma are Southern Entomologists, and S. Smith is Regional Entomologist, U.S. Forest Service Region 5; S. Cousins is Assistant Professor and A. Poloni is Masters Student, Department of Natural Resources Management and Environmental Sciences, California Polytechnic State University; B. Estes is Central Sierra Province Ecologist and H. Safford is Regional Ecologist, U.S. Forest Service Pacific Southwest Region; C. Fettig is Research Entomologist and L. Mortenson is Biological Science Technician, U.S. Forest Service Pacific Southwest Research Station; S.M. Hood is Research Ecologist, U.S. Forest Service Rocky Mountain Research Station; S. Kocher is Cooperative Extension Forestry Advisor Central Sierra, UC Agriculture and Natural Resources; D. McMahon is Ph.D. Candidate, Department of Earth System Science, Stanford University; A. Koltunov is Associate Project Scientist, Center for Spatial Technologies and Remote Sensing (CSTARS), UC Davis; C. Ramirez is Vegetation Mapping and Inventory Group Leader and $M$. Slaton is Ecologist, U.S. Forest Service Region 5 Remote Sensing Lab; C. Restaino is Forest Ecosystem Health Program Manager, Tahoe Regional Planning Agency; R. Wayman is Associate Specialist, Department of Environmental Science and Policy, UC Davis; and D. Young is Postdoctoral Researcher, Department of Plant Sciences, UCDavis.

\section{References}

California Forest Pest Council. 2017. California Forest Pest Conditions. www.fs.usda.gov/Internet/ FSE_DOCUMENTS/ fseprd578546.pdf.

Fettig CJ, Mortenson LA, Bulaon BM, Foulk PB. 2019. Tree mortality following drought in the central and southern Sierra Nevada. Forest Ecol Manag 432:164-78.

Griffin D, Anchukaitis KJ. 2014. How unusual is the 2012-2014 California drought? Geophys Res Lett 41:9017-23.

He M, Schwarz A, Lynn E, Anderson M. 2018. Projected Changes in Precipitation, Temperature, and Drought across California's Hydrologic Regions.

California's Fourth Climate Change Assessment. Pub no. CCCA4-EXT-2018-002

California Department of Water Resources.

Restaino CD, Young B, Estes S, et al. 2019. Forest structure and climate mediate drought-induced tree mortality in forests of the Sierra Nevada, USA.

Ecol Appl, in press.

Stephens SL, Collins BM, Fettig CJ, et al. 2018.

Drought, tree mortality and wildfire in forests adapted to frequent fire. BioScience 68:77-88.

Swain DL. 2015. A tale of two California droughts: Lessons amidst record warmth and dryness in a region of complex physical and human geography. Geophys Res Lett 42:999910003

[USDA] United States Department of Agriculture. 2019. Survey Finds 18 Million Trees Died in California in 2018. Press release. Feb. 1, 2019. www.fs.usda gov/Internet/FSE_DOCU MENTS/FSEPRD609321.pdf (accessed Feb. 15, 2019). 


\section{Tree mortality in the Sierra Nevada studies}

\section{UC Berkeley, UC ANR mortality study}

Jodi Axelson, John Battles, Lauren Cox, Susie Kocher and Elliot Kuskulis

Mortality and regeneration study, 283 plots on eight sites, in mixed-conifer elevation bands, north to south Sierra Nevada.

- Tree mortality lowest in north, highest in south (fig. 1A), mirroring pattern detected by USFS ADS (California Forest Pest Council 2017).

- Tree mortality largely driven by bark beetles; fir engraver (Scolytus ventralis) the most damaging.

- Sapling and seedling density in 2018 highly variable across sites; most abundant were shade-tolerant species such as white fir (Abies concolor) and incense cedar (Calocedrus decurrens) (fig. 1B).

- In 2018, white fir experienced the highest tree fall rate, 3\%, and ponderosa pine the lowest, just over $1 \%$.

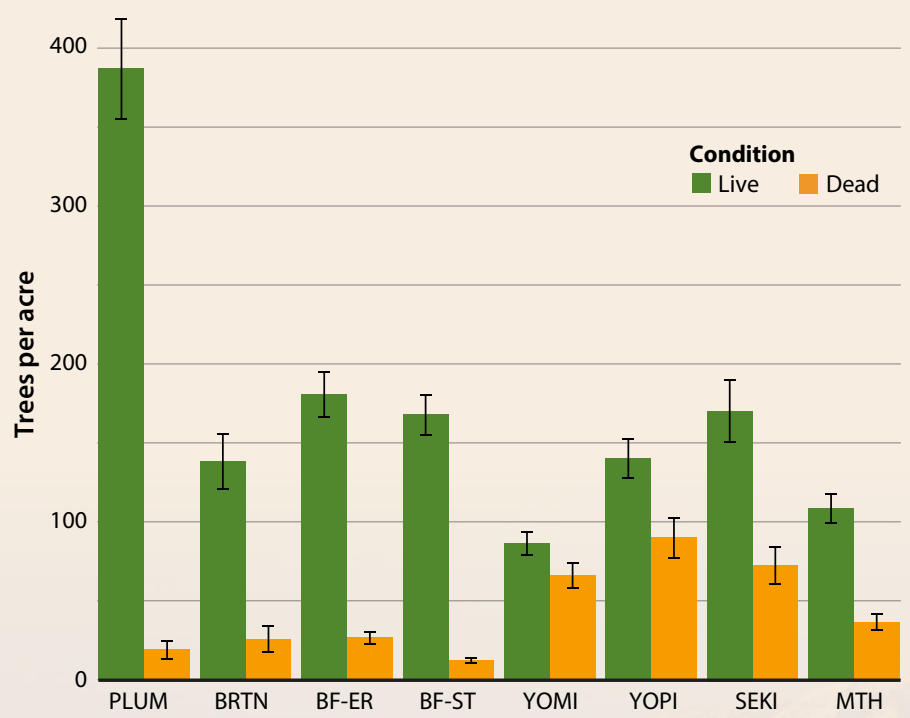

FIG. 1A. Mean number of live and recently dead trees per acre (+ standard error of the mean, SEM), 2018. Sites, from north to south: Plumas National Forest, Burton Creek State Park, Blodgett Research Forest - Ecological Reserve, Blodgett Research Forest - Single Tree Selection, Yosemite National Park (mixed conifer), Yosemite National Park (pine), Sequoia-Kings Canyon National Park, Mountain Home State Demonstration Forest (Axelson et al., in preparation).
- Predictions for Sequoia-Kings Canyon National Park from 2017 to 2030: 31\% loss of live tree biomass, 330\% increase in dead tree biomass, doubling of $1,000+$ hour fuels ( $\geq 3$ inches).

- Predictions across all sites in the network, 2017-2030: 75\% of plots will have greater than 100 tons per acre of downed and dead wood.

- More information at https://ucanr.edu/delivers/?impact= 1077\&delivers $=1$.

Researchers will remeasure components of the plots annually to track tree status, bark beetle activity, dead tree fall rates, fuel accumulations and understory response.

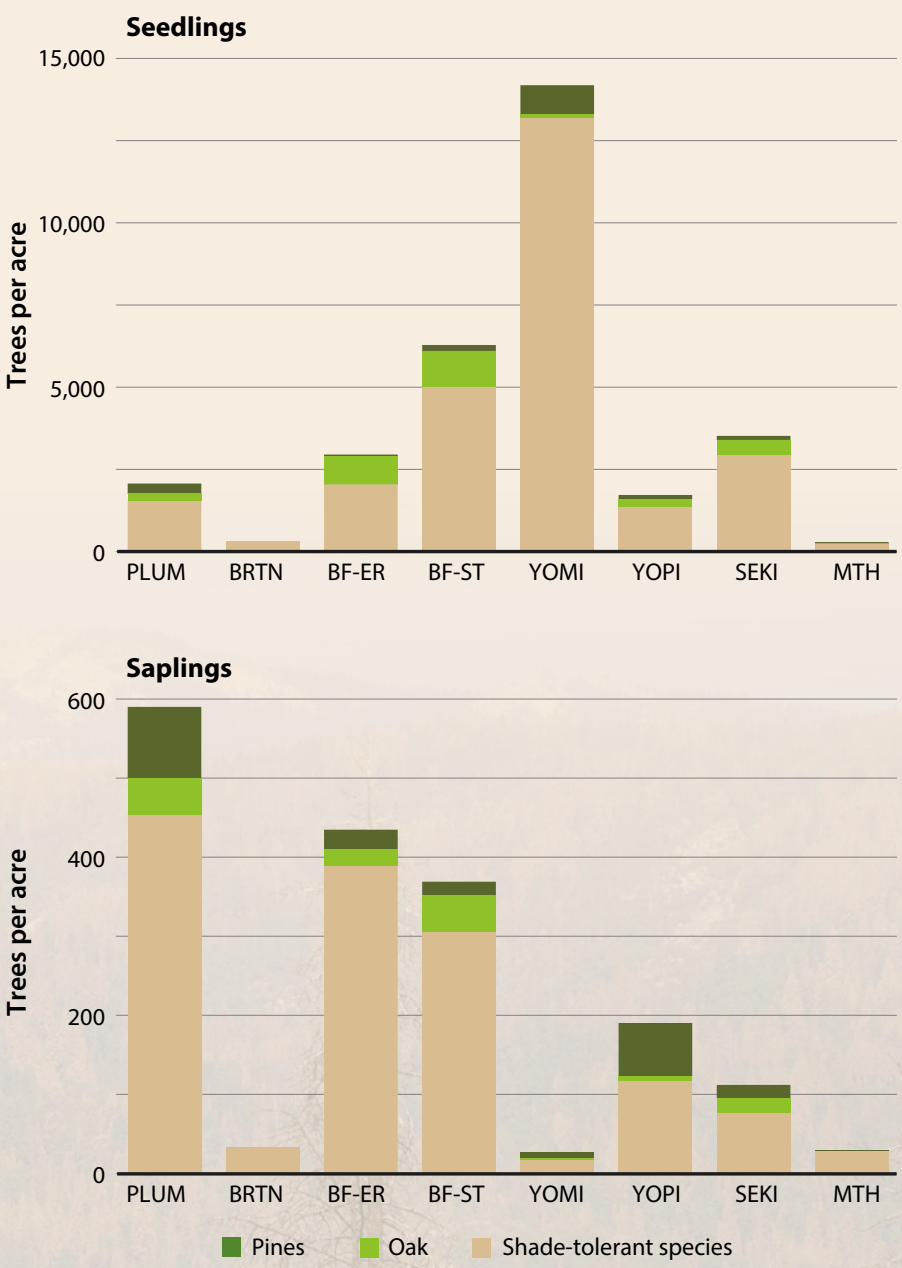

FIG. 1B. Mean number of seedlings (top) and saplings (bottom) per acre, 2018, categorized as pines (ponderosa and sugar pine), oak (black oak) and shade-tolerant species (white fir, incense cedar and Douglas fir) (Axelson et al., in preparation). 


\section{U.S. Forest Service Region 5 thinning study}

Becky Estes, Derek Young and Christina Restaino

Effects of thinning on tree mortality along a latitudinal gradient in forests on National Forest, National Park and Bureau of Land Management lands.

- Thinning effectiveness decreased along the latitudinal gradient to the southern Sierra, where water stress was so high that stand density was less important (fig. 2A).

- Thinning substantially reduced mortality in central Sierra.

- In 2017, even in thinned, high-mortality plots, the density of surviving canopy trees (> 3-inch diameter) was 18 per acre; regeneration ( $<3$-inch diameter) was 76 per acre, suggesting that most stands will recover reasonable densities naturally.

- Drought mortality (concentrated in pines) has led to species shift. Among surviving canopy trees and regeneration, there was an unnaturally high relative abundance of shade-tolerant conifer species; pre-drought thinning reduced this effect (fig. 2B).

Researchers will document changes in stand resilience by evaluating residual structure and composition.

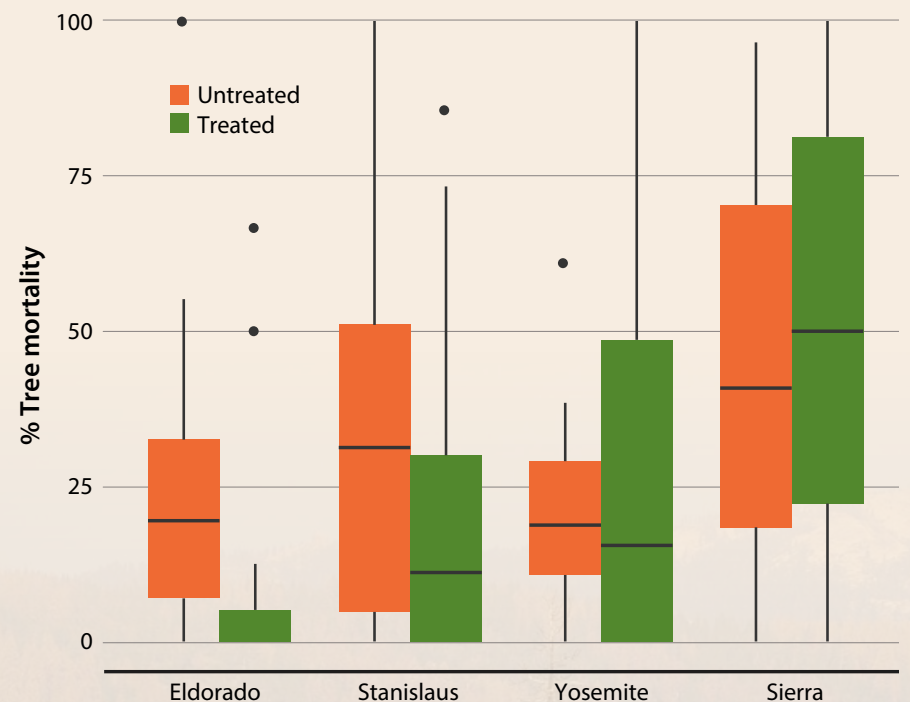

FIG. 2A. The effectiveness of thinning treatments decreased from the central to southern Sierra Nevada (Restaino et al., in press).

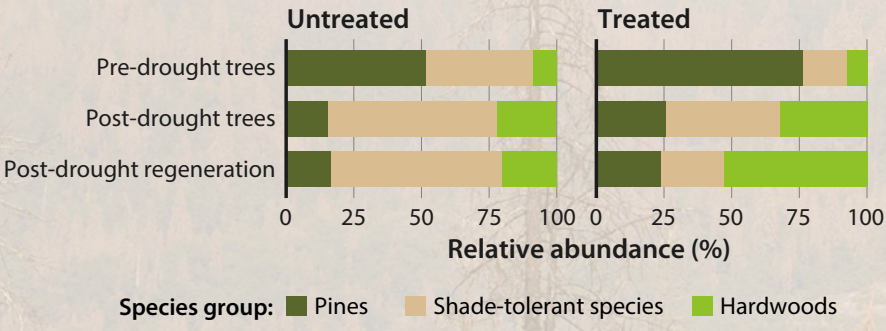

FIG. 2B. Drought has increased the dominance of shade-tolerant species, especially in unthinned stands. Thinned stands include more pines and hardwoods (Young et al., in review).

\section{U.S. Forest Service Pacific Southwest Research Station mortality study}

Chris Fettig, Leif Mortenson and Beverly Bulaon

Study in high-mortality areas, at three elevational bands, in the Eldorado, Stanislaus and Sequoia National Forests.

- Mortality most severe in 2016 (fig. 3) and concentrated in largerdiameter conifer trees - in 3 years only one oak (Quercus) died.

- Between 2014 and 2017, 48.9\% of trees died (fig. 3), and there were higher levels of mortality at low elevations (60.4\%) than at high elevations (46.1\%).

- Mortality mostly attributed to western pine beetle (Dendroctonus brevicomis; WPB)

- Ponderosa pine (Pinus ponderosa), the only host of WPB in the area, suffered highest levels of tree mortality, from $18.2 \%$ to $100 \%$ per plot.

- $39 \%$ of plots lost all ponderosa pine.

- Sugar pine (Pinus lambertiana) experienced $48 \%$ mortality, concentrated in mid-diameter trees, most due to mountain pine beetle (Dendroctonus ponderosae).

- White fir mortality at 26\%, most due to fir engraver.

- Mortality positively correlated with tree density (Fettig et al. 2019). As funding allows, researchers will remeasure plots on a regular basis.

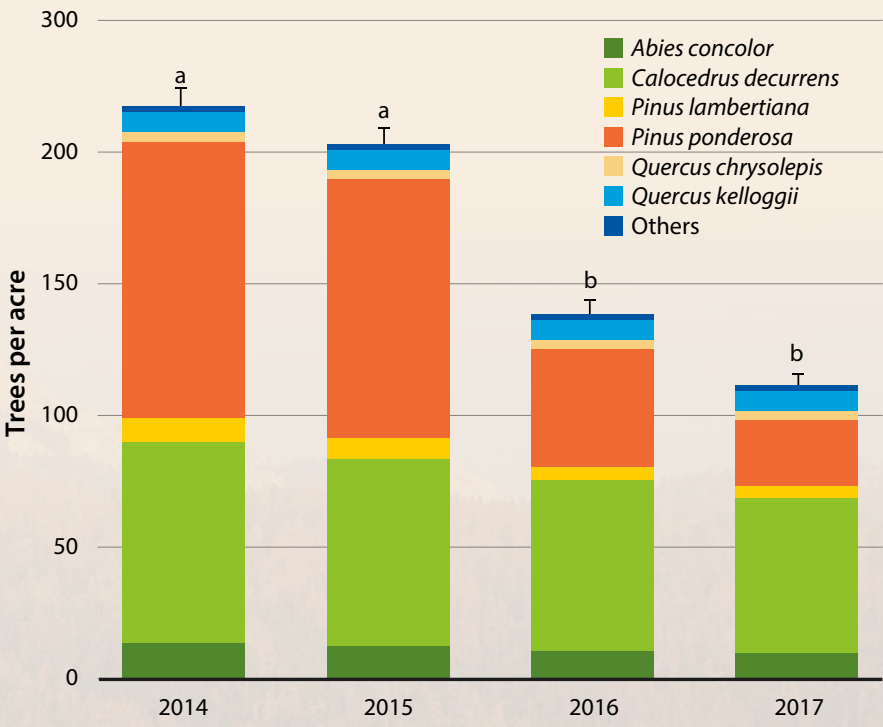

FIG. 3. Mean number of trees per acre by species (+ standard error of the mean, SEM), 2014-2017. Ponderosa pine (Pinus ponderosa) has suffered the highest levels of mortality. Means ( + SEM) followed by the same letter are not significantly different $(P>0.05)$. Adapted from Fettig et al. (2019). 


\section{U.S. Forest Service Rocky Mountain Research Station vegetation and fuels monitoring study}

Sharon Hood, Sheri Smith, Danny Cluck, Beverly Bulaon, Stacy Hishinuma, Andrea Hefty and Adrian Poloni

Vegetation and fuels monitoring study plots on Sierra and Los Padres National Forests in areas of high and low tree mortality.

- In 2017, on the Sierra National Forest, mortality was high, especially in pines - 93\% mortality of sugar pine, $89 \%$ of ponderosa pine.

- In 2017, areas of high mortality, no clear difference in tree size between live and dead white fir and incense cedar; dead red fir (Abies magnifica) trees smaller than living red fir; dead ponderosa pine trees larger than living ones.

- Regeneration in Sierra study plots mainly white fir

- From 2016 to 2018, an average of 19\% of new snags (i.e., trees that died since 2014) fell; 64\% broke below 15 feet, 34\% broke at 0 feet (table 1).

- Fuel loading is very high, particularly in 1,000+ hour class.

TABLE 1. Percentage of snags that broke or fell from 2016 to 2018

\begin{tabular}{|l|c|}
\hline Species & Broken or fallen (\%) \\
\hline White fir & 18 \\
\hline Red fir & 26 \\
\hline Incense cedar & 35 \\
\hline Sugar pine & 13 \\
\hline Ponderosa pine & 22 \\
\hline Piñon pine & 10 \\
\hline
\end{tabular}

Researchers will remeasure plots annually for 5 years to follow changes in tree status and fuel loading, and use dendrochronology data to compare the growth of trees that lived with the growth of those that died recently.

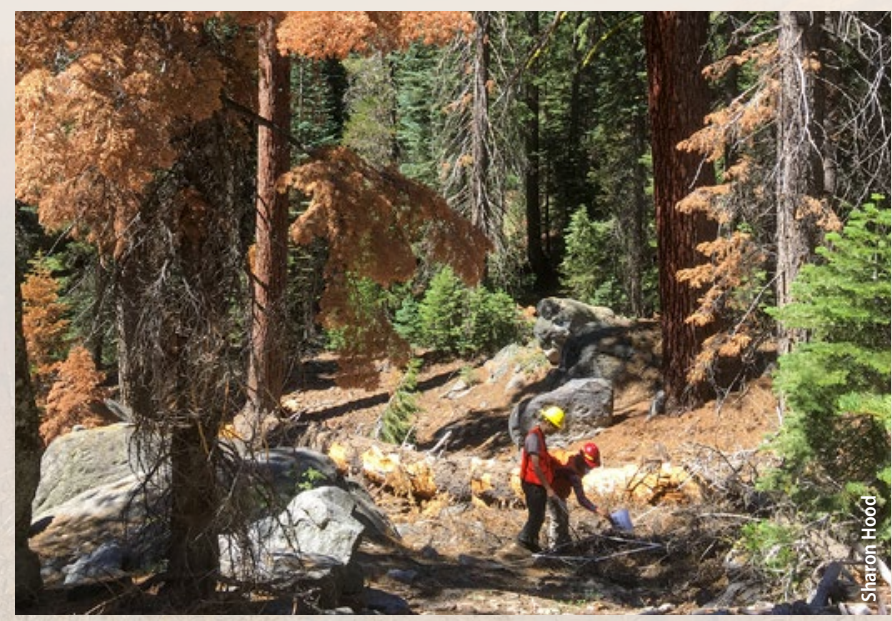

In the Sierra National Forest, Adrian Poloni (then at UC Davis) and Lindsay Grayson (USFS Rocky Mountain Research Station) sample fuels in an area of high mortality. Red trees are recently dead white fir.

\section{UC Davis, U.S. Forest Service study on effects of tree mortality on wildfire severity}

Rebecca Wayman and Hugh Safford

Study on how recent tree mortality has influenced wildfire severity in forests that historically experienced frequent fires, 180 plots on the 2015 Rough fire (150,000 acres) and 2016 Cedar fire $(30,000$ acres) in the southern Sierra Nevada.

- In the Cedar fire, influential variables on fire severity were weather metrics and the severity of pre-fire red phase tree mortality.

- In the Rough fire, the most influential variable on fire severity was the severity of pre-fire red phase tree mortality, followed closely by stand basal area.

- Increasing levels of pre-fire tree mortality up to 30\% to $45 \%$ corresponded to increasing fire severity on both fires, but higher levels of tree mortality were not associated with further increases in fire severity.

Researchers will continue to analyze data and hope to publish results in 2019.

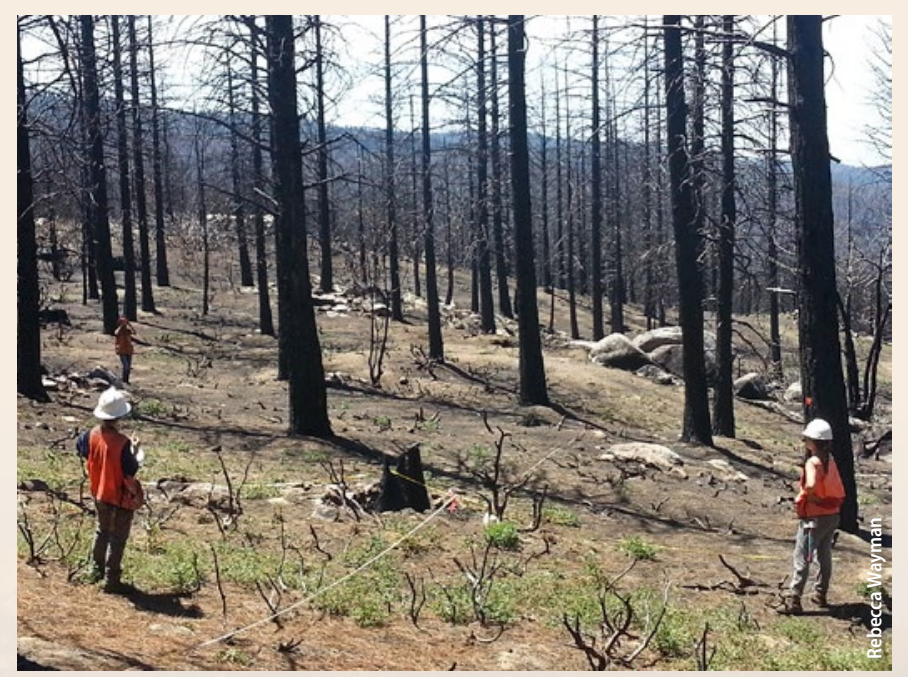

In the footprint of the 2015 Rough fire, UC Davis crew members collect plot data 1 year post-fire to evaluate the relationship between pre-fire tree mortality and wildfire severity. 


\section{UC Berkeley, U.S. Forest Service field-based mortality inventories}

Stella Cousins and colleagues

Field-based inventories conducted by the USFS Forest Inventory and Analysis Program (FIA), 2,800 plots (one for every 6,000 acres) on California forests, all ownership types.

- 2012-2015 estimate of mortality in Sierra Nevada: 167 million trees.

- From 2011 to 2016, over 79,000 trees were remeasured — mortality rates more than doubled since 2001-2003.

- Leading causes of tree mortality were fire, harvest and unknown causes. Mortality primarily caused by pests or pathogens was $24 \%$ of nonharvest mortality.

- Largest increases in mortality were among red fir, white fir and sugar pine.

- Mortality in smaller trees (<30-inch diameter) highest in white and red fir; for largest trees, highest in sugar pine.

Researchers will continue to investigate patterns of tree mortality over time.

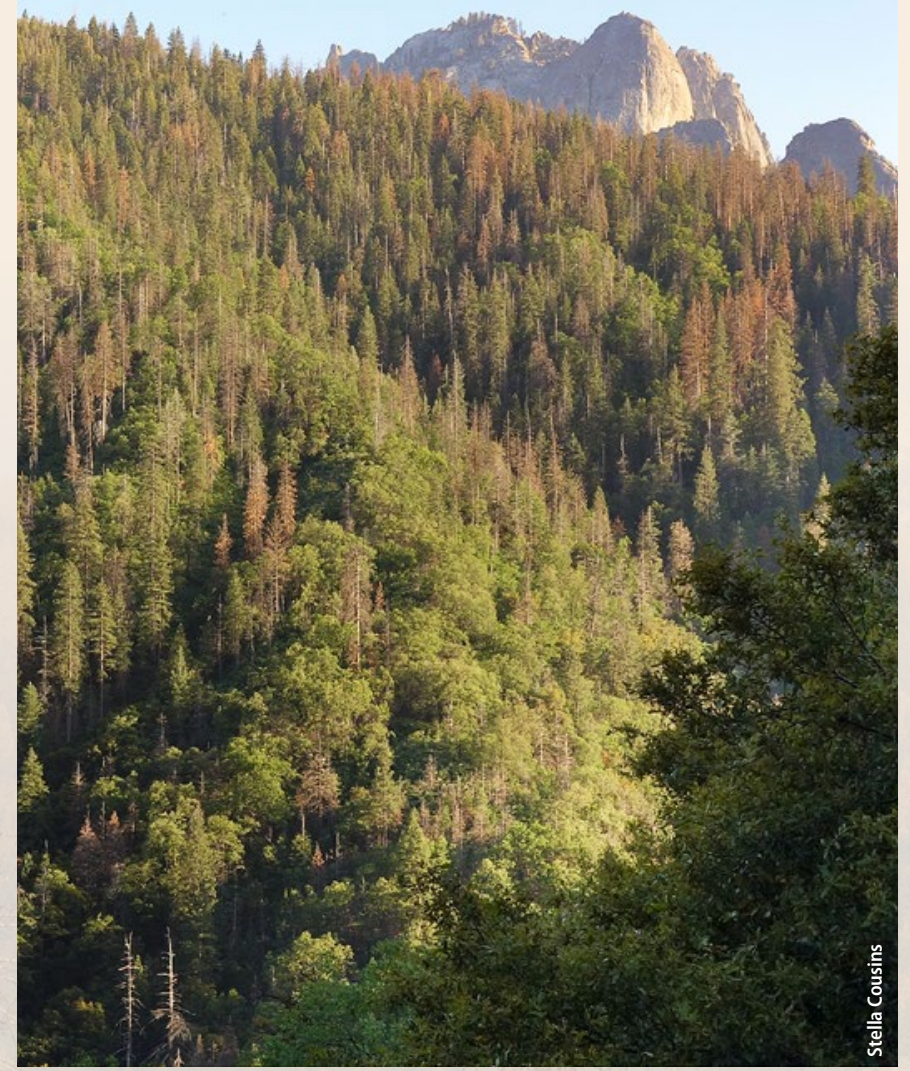

Mortality in pines and firs at elevations from 4,000 to 7,000 feet, June 2018 , on the middle fork of the Kaweah River mirrors FIA data - tree mortality increasing at all elevations where forests are found and affecting many species.

\section{U.S. Forest Service Region 5 western pine beetle study}

Sheri Smith, Beverly Bulaon, Danny Cluck, Andrea Hefty, Stacy Hishinuma and Adrian Poloni

Examined historic research on western pine beetle (WPB) lifecycle timing, numbers of generations and winter temperature data; in 2017 conducted field-based monitoring of WPB to compare to historical baseline.

- Timing and number of WPB generations nearly identical to historic observations (1930s), even during hottest summer on record.

- 2017 field data indicated that there were two full and one partial generations of WPB on Lassen and Stanislaus National Forests.

- Most areas on west slope of Sierra Nevada, especially at lower elevations, likely never experienced cold enough temperatures (ambient air temperatures of $-15^{\circ} \mathrm{F}$ to $-20^{\circ} \mathrm{F}$ for an extended period) to result in WPB mortality or affect outbreaks.

More monitoring is needed in other parts of California over longer timeframes to better describe year-to-year variation and detect any differences in beetle biology from historic record.
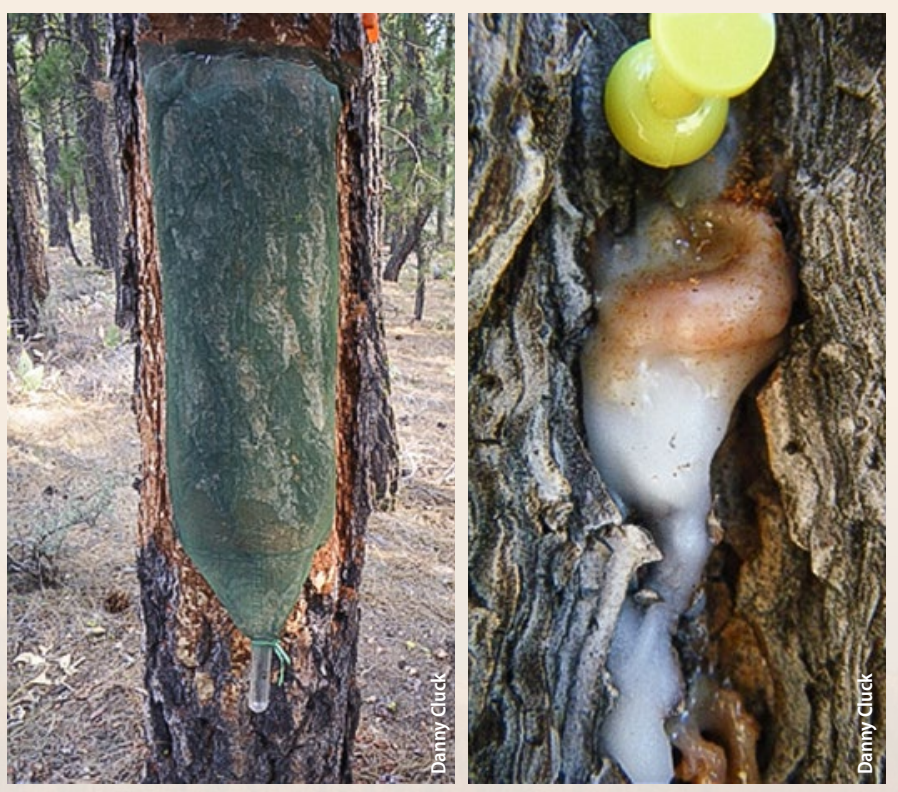

In the Lassen National Forest, western pine beetle emergence and new attacks were monitored weekly. A screen attached to a ponderosa pine, left, helps determine the timing and number of emerging beetles. A pin near a pitch tube, right, marks an attack since the previous monitoring period. 


\section{UC Berkeley, UC ANR biomass harvesting study}

Carmen Tubbesing and colleagues

Mapping standing dead tree biomass with remotesensing technology, determining how much of it could be feasibly harvested for energy, estimating harvesting and transporting costs.

- Estimated 23.6 to 86.3 million metric tonnes of aboveground tree biomass died 2012-2017, peak in 2016.

- $82 \%$ to $85 \%$ of mortality in 10 counties.

- More- and less-feasible areas for biomass harvest characterized based on slope, geographic isolation, average volume per tree, wilderness/National Park status.

- $29 \%$ of standing dead biomass (6.9 to 25.3 million metric tonnes) "more" feasible for harvest.

- Biomass tool (fig. 4): http://geodata.ucanr.edu/ biomass/.

The next step is to estimate harvest and transportation costs statewide, using an approximation of the Fuel Reduction Cost Simulator (FRCS) and Google Maps road data.

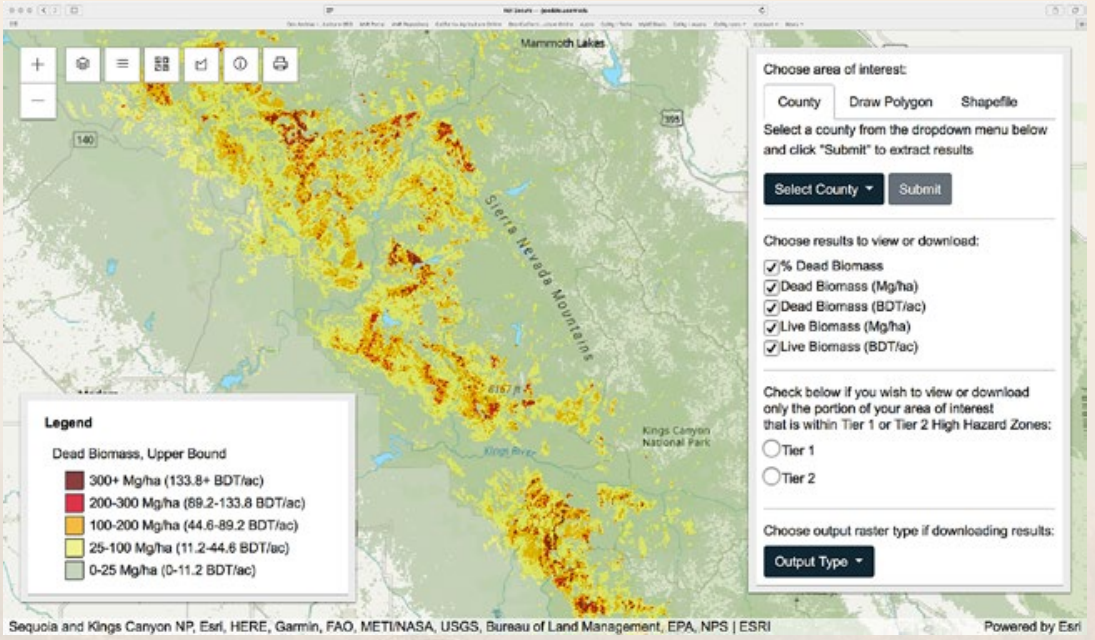

FIG. 4. Collaborating with UC ANR's Informatics and GIS Program (IGIS), Tubbesing and colleagues developed a web tool for site-based biomass estimates. Users can access results by area of interest, from state, to county (shown), or a smaller area drawn on the screen.

\section{U.S. Forest Service Region 5 Remote Sensing Lab, UC Davis Center for Spatial Technologies and Remote Sensing (CSTARS) eDaRT development}

Carlos Ramirez, Michèle Slaton and Alexander Koltunov

Developed eDaRT (Ecosystem Disturbance and Recovery Tracker) to generate forest disturbance maps and provide customized data products and information services to forest managers, ecologists and wildlife biologists (fig. 5).

- High accuracy and superior spatial and temporal resolutions of maps.

- Refined correlative relationships among disturbances and processes, such as fire, forest thinning and tree mortality.

- Sierra Nevada-wide estimates of forest change due to tree mortality.

- Fine-scale change detection that facilitates projectlevel restoration planning and monitoring.

- $2 \%$ statewide loss in whitebark pine (Pinus albicaulis), a candidate for U.S. Endangered Species Act.

Researchers will characterize forest disturbance by type (e.g., mortality, fire, harvest), improve disturbance magnitude metrics, reformat and deploy the system for near-real time operation, incorporate imagery from satellites other than Landsat, expand product validation efforts, and other developments.
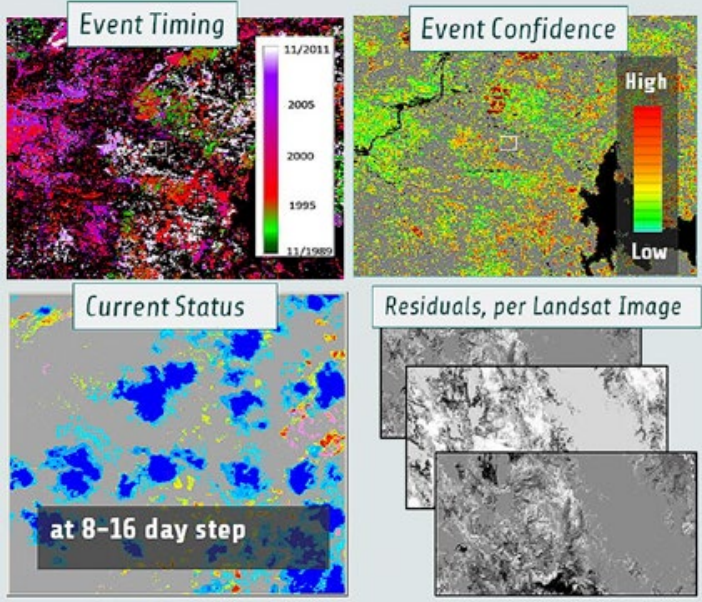

Residuals, per Landsat Image

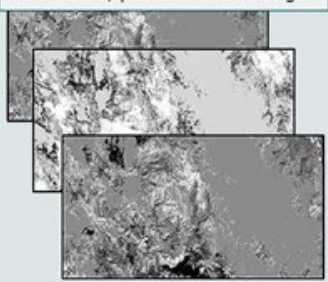

No Change

Non-Forest Changes

Disturbed estimated relative change in vegetation cover, greenness and moisture content. More information at www. cstarsd3s.ucdavis.edu/systems\#a-sys-drt. 


\title{
To build a walled garden
}

\author{
Through cooperative ventures around the state, the UC Master Gardener program brings \\ horticultural knowledge to Californians in jails, detention centers and treatment facilities.
}

Youths at the Kings County Juvenile Center get down to work as part of a UC Master Gardener project. Research shows that gardening provides physical, emotional, social and economic benefits to those who participate in it.

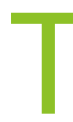

he UC Master Gardener Program delivers research-based information to the public, but not every member of the public is in public. Some reside temporarily in jails, detention centers or treatment facilities - so the UC Master Gardener Program meets them where they are.

In San Diego County, the UC Master Gardener Program conducts outreach at the County of San Diego Girls Rehabilitation Facility. In this collaboration with San Diego County's Probation Department and Office of Education, UC Master Gardener volunteers visit the facility twice a week to teach skills such as planting, irrigation and crop rotation. The young women eat the product of their labor - and also cultivate pollinating plants to attract monarch butterflies. Dayle Cheever, a UC Master Gardener volunteer, reports that staff at the facility have "truly embraced" the gardening initiative - and that many young women ask how to continue gardening, or pursue horticulture as a career, after they leave the facility.

In Sonoma County, through the Propagation for Education project, UC Master Gardener volunteers provide horticultural training to inmates at the North County Detention Facility. The project, a cooperative undertaking with the Sonoma County Sheriff's Office and Office of Education, focuses on propagation of plant materials such as shrubs, trees, perennials and ornamental plants. "My guys really soak it up," says Rick Stern, an adult corrections teacher with the county's Office of Education. Many inmates, after they leave the facility, retain an interest in gardening - they "always have a question" when Stern encounters them around town. And even if former inmates don't pursue horticulture as a career, they can share in the physical, emotional, social and economic benefits that, according to research, gardening confers on its practitioners (Benham 2014; Waitkus 2004).

A bit further south, UC Master Gardener volunteers collaborate with the Behavioral Health Division of Contra Costa Health Services to deliver gardening programs at four residential substance-abuse facilities - some of whose residents, having faced a choice between treatment and prison, chose treatment. UC Master Gardener volunteers such as Darlene DeRose visit the facilities several times a month, giving lessons on basic vegetable gardening topics such as soils, pollinators and pests. The lessons are followed by hands-on gardening work.

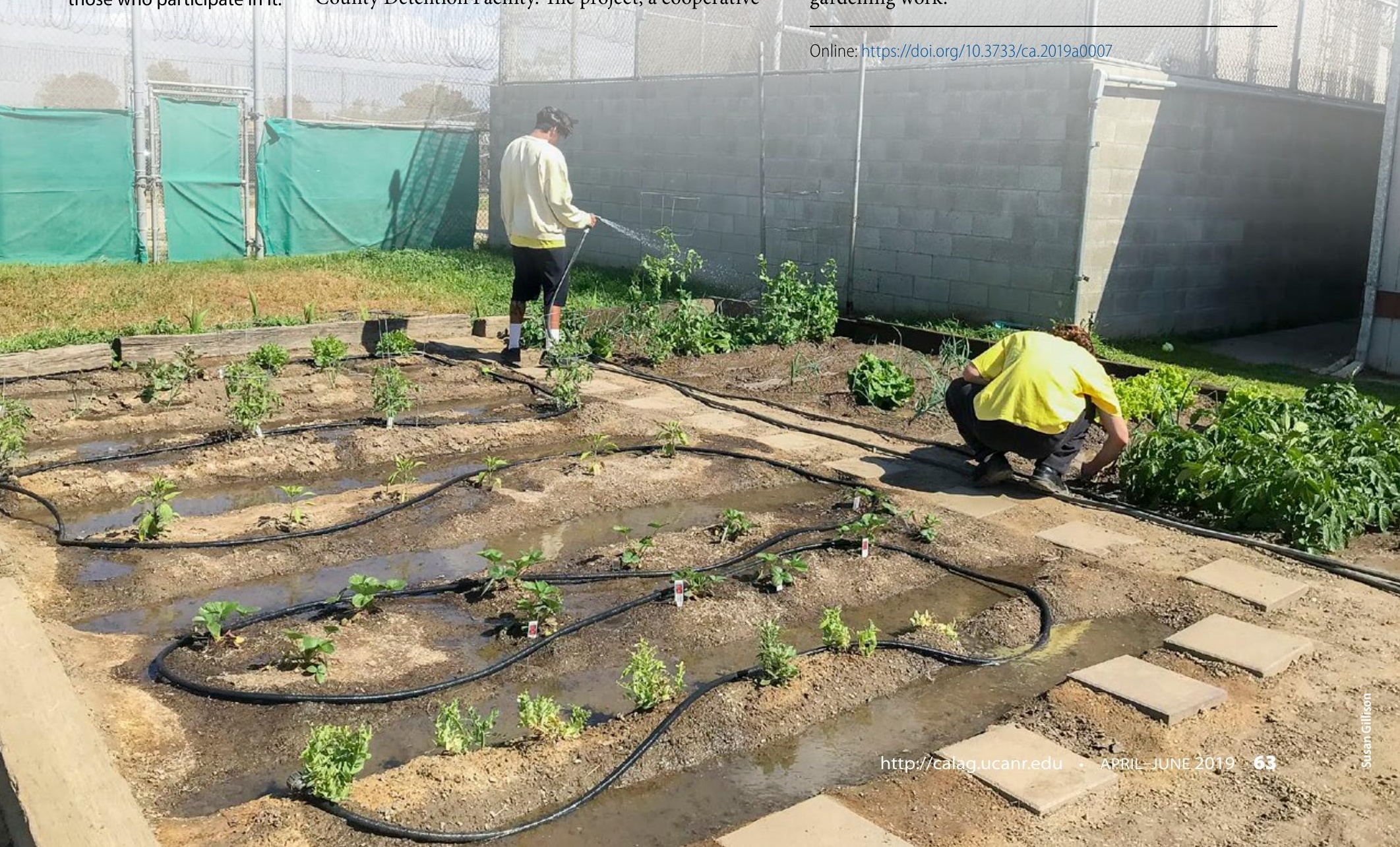




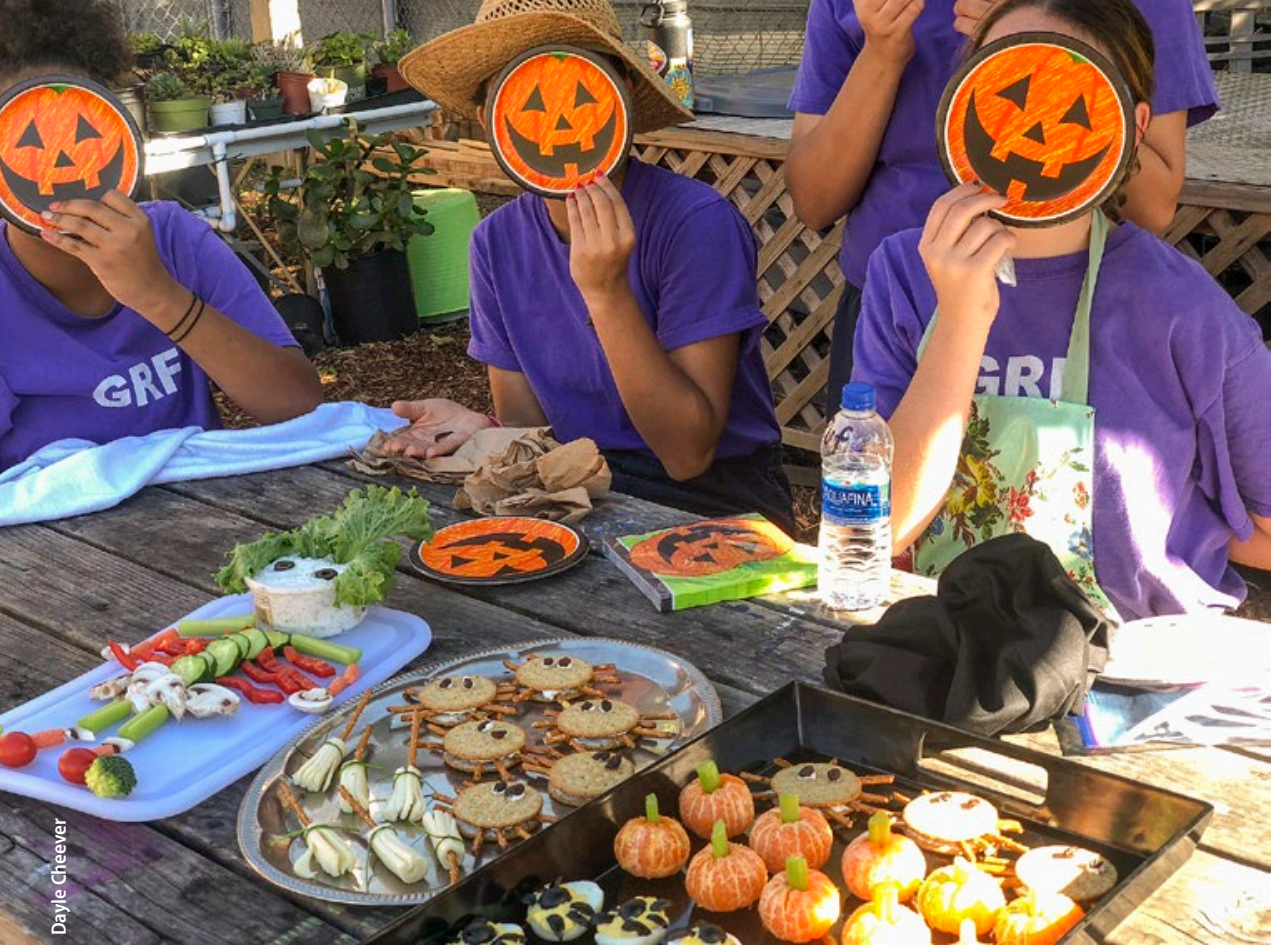

Young women at the County of San Diego Girls Rehabilitation Facility, participating in a UC Master Gardener project, get in the Halloween spirit.

A floral design adorns the ground at the County of San Diego Girls Rehabilitation Facility. Young women participating in the facility's UC Master Gardener project grow pollinating plants to attract monarch butterflies.

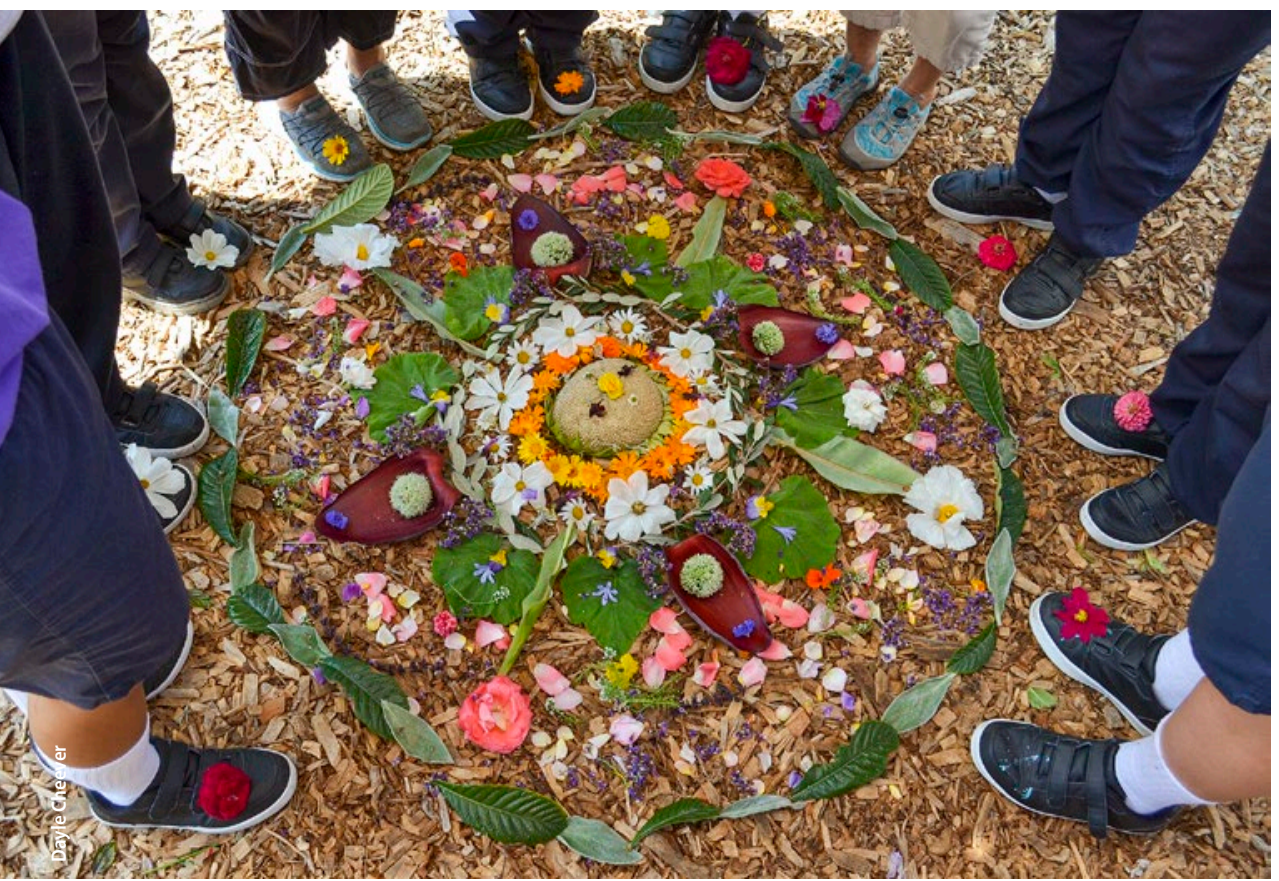

When UC Master Gardener volunteers began the project, DeRose says, "One facility had small raised beds, lying fallow, and the others had nothing." Today, the gardens yield plentiful fresh food that the residents harvest and make into meals. The participants are generally eager to learn, DeRose reports, though they

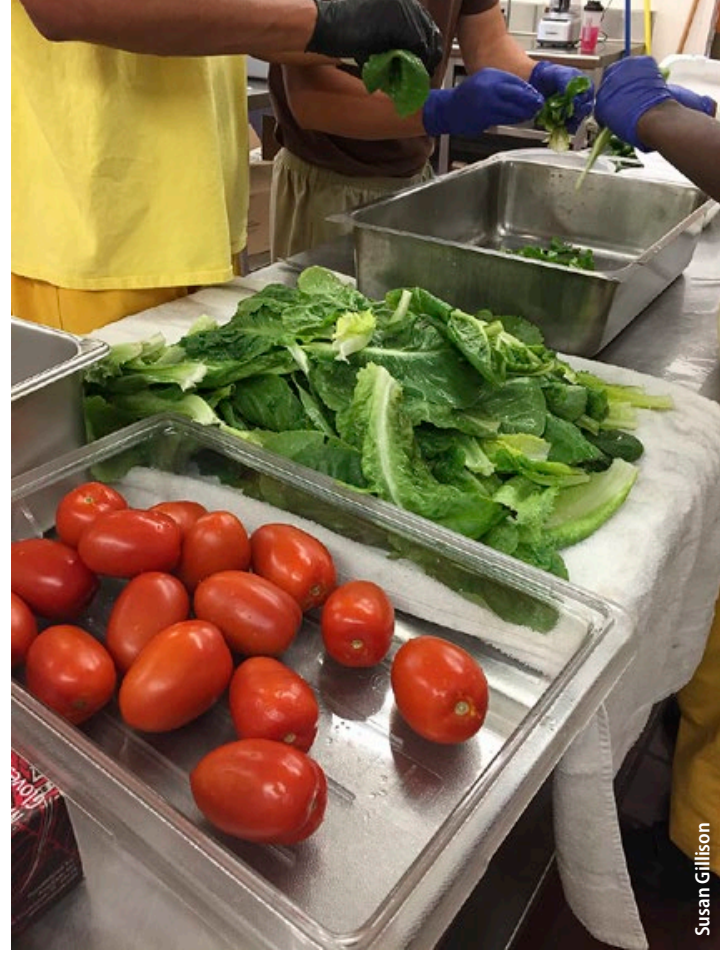

Incarcerated youth at the Kings County Juvenile Center prepare food grown on site.

educational and social services center for youth, on a project called the Leadership Garden. At Rancho Cielo, students aged 16 to 24 work toward high school diplomas as they develop marketable work skills. A majority of the students are on probation or parole - but others have had no dealings with the law, and all are free to come and go.

When UC Master Gardener volunteers such as Julie about basic things" - some students, for example, want to get rid of bees. The volunteers have learned lessons too, such as what to grow and not grow (lettuce is popular, eggplant anathema).

In Monterey County, the UC Master Gardener Program collaborates with Rancho Cielo, an Lorenzen visit, students from Rancho Cielo's culinary academy venture to the garden to work and learn. Most of the garden's harvest is sent to the academy's restaurant, where students prepare it for paying customers. When Lorenzen was interviewed for this article, the

restaurant was featuring Jerusalem artichokes from the Leadership Garden - and on the Monday preceding, the garden had yielded 28 pounds of leeks and 10 pounds each of lemons and mandarin oranges. That's a nice haul. But to Lorenzen, the garden is more than citrus fruit and aromatics. "Aside from raising my own children," she says, the Leadership Garden is "the most rewarding thing I've ever done." CA

- Lucien Crowder

\section{References}

Benham MK. 2014. From Utility to Significance: Exploring Ecological Connection, Ethics and Personal Transformation through a Gardening and Environmental Literacy Program within San Quentin State Prison. Master's thesis, San Jose State University, Department of Environmental Studies. https://scholarworks.sjsu. edu/etd_theses/4452

Waitkus KE. 2004. The Impact of a Garden Program on the Physical Environment and Social Climate of a Prison Yard at San Quentin State Prison. Master's thesis, Pepperdine University, School of Business and Management. https://pepperdine.contentdm.oclc org/digital/collection/p15093coll2/id/94 


\title{
Research highlights
}

\author{
Recent articles from the Agricultural Experiment Station campuses and UC ANR's county offices, \\ institutes and research and extension centers.
}

Online: https://doi.org/10.3733/ ca.2019a0003

Burned and logged forests have traditionally been replanted with pine seedlings planted on a regularly spaced grid (top, at 50 years old), which does not develop the mature forest clump and gap spacing (bottom) that historically was produced by frequent low-intensity fire, a pattern associated with forests resilient to drought and wildfire.

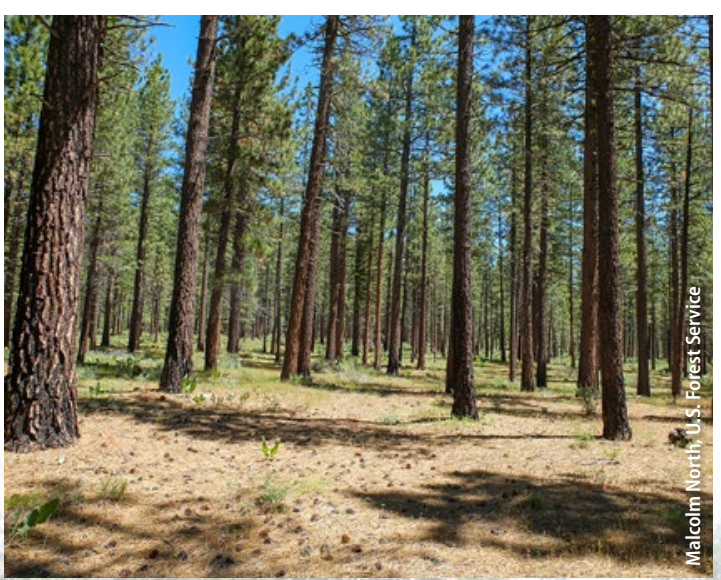

\section{Potential improvements to reforestation practices identified}

n many forests in the western United States, increasingly frequent and severe wildfire and drought have hindered capacity for successful forest reforestation. Efforts to re-establish forests are often complicated by challenges such as high mortality rates for seedlings and saplings amid water stress and repeat fire events. Standard reforestation practices center on establishing dense conifer cover through gridded planting, followed by shrub control and pre-commercial thinning. These intensive management practices are increasingly constrained by factors such as shrinking budgets for, and work forces on, public lands. A team drawn from the Department of Plant Sciences at UC Davis and the Department of Environmental Science, Policy and Management at UC Berkeley assessed recent research into reforestation practices in the western United States, examining which practices might benefit from adjustment. They specifically examined whether replantings characterized by regular tree spacing increase the risk of future mortality. They also examined how the density, spatial arrangement and species composition of replantings might be modified to foster greater survival amid recurring fire and drought. The authors suggest that large areas of contiguous tree mortality

can most productively be replanted in three distinct zones: a peripheral zone near sources of live tree seeds, where regrowth depends on natural recruitment; a second zone, beyond effective seed dispersal but nonetheless accessible, where both regularly spaced and clustered seedlings are planted in patterns varying with water availability and potential fire behavior; and a third zone on steep, remote terrain where reforestation efforts are limited, in practice, to establishing founder stands. The authors also recommend that prescribed fire be employed in reforested areas to build fire resilience in developing stands.

North MP, Stevens JT, Greene DF, et al. 2019. Tamm review: Reforestation for resilience in dry western U.S. forests. Forest Ecol Manag 432:209-24. https://doi.org/10.1016/j.foreco.2018.09.007

\section{Local reforestation program plays key role in landowner decisions after devastating fire}

mid increasingly severe wildfire and the growAing threat of climate change, California's Forest Carbon Plan identifies reforestation as one means of carbon sequestration and climate mitigation. Researchers from the Department of Environmental Science, Policy and Management at UC Berkeley and from UC Cooperative Extension (UCCE) interviewed 27 owners of nonindustrial forest land whose properties had burned in a 2014 wildfire in the central Sierra - and who were eligible to participate in a program offered by the nearby resource conservation district, a locally governed entity charged with providing tools and technical assistance to protect land and water resources. The interviews were designed to gain insight into landowners' perceptions of burned forest land; their vegetation management decisions after the fire; and their experiences with programs that provide reforestation assistance. Many landowners reported that fire-related landscape changes had provoked an intense, lasting emotional reaction in them. All respondents reported that they had wanted to reforest their land but onethird reported that they would not have done so if the resource conservation district had not offered a free reforestation program. Though many respondents recognized the value of replanting for purposes of climate mitigation, few considered the possibility that adapting 
reforestation prescriptions could provide climate benefits. The authors suggest that reforestation projects for climate change mitigation should also include outreach emphasizing the benefits that climate-adapted forest management practices confer on efforts to maintain and enhance resilience in the face of climate change.

Waks L, Kocher SD, Huntsinger L. 2019. Landowner perspectives on reforestation following a high-severity wildfire in California. J Forest 117(1):30-7. https://doi.org/10.1093/jofore/fvy071

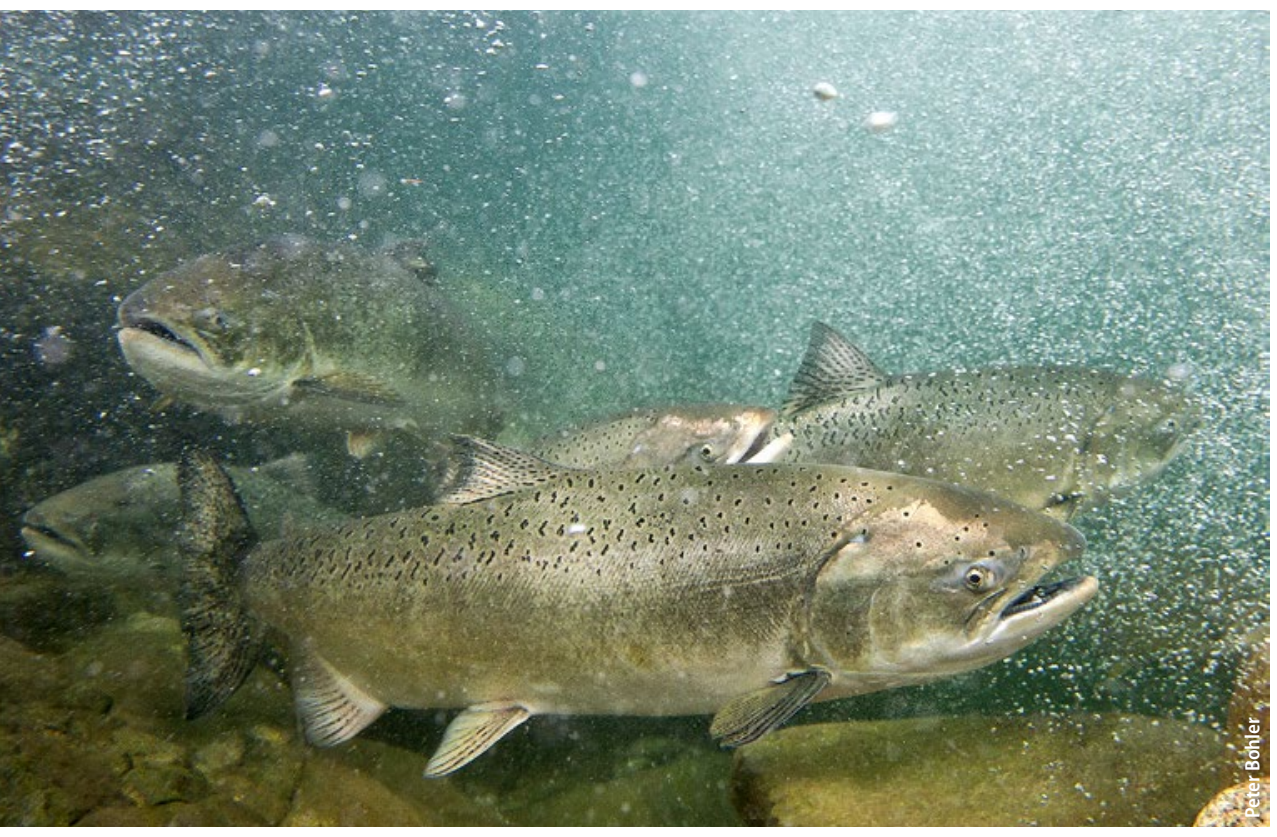

Performing genetic analysis of chinook salmon in Oregon's Rogue River, UC Davis scientists found a robust association between migration phenotype (spring run or fall run) and a single genetic locus. A dramatic change in allele frequency at this locus explained the rapid phenotypic shift that researchers observed after a recent dam construction.

\section{Loss of spring-run chinook salmon is rapidly followed by loss of potential for recovery}

henotypes are the overall observable characteristics of individual organisms. Variation in phenotype is crucial if species and populations are to persist over the long term, but human activity has substantially shifted and reduced phenotypic variation across many taxa. The underlying mechanisms (genetic or environmental) and long-term consequences of such shifts, however, are often unclear. UC Davis researchers including Tasha Thompson, Sean O'Rourke and Michael Miller of the Department of Animal Science investigated widespread changes, caused by dam construction and other anthropogenic activities, in the adult migration characteristics of wild chinook salmon. Performing genetic analysis of chinook salmon in Oregon's Rogue River, they found a very robust association between spring-run or fall-run migration phenotype and a single genetic locus. Further, they found that a dramatic change in allele frequency at this locus explained a rapid phenotypic shift observed after recent dam construction. The researchers' modeling suggests that continued selection against the spring-run phenotype could lead to rapid and complete loss of the spring-run allele. Meanwhile, the researchers' empirical analysis of chinook salmon populations that have already lost the spring-run phenotype indicates that these populations are not acting as sustainable allele reservoirs. Analysis of ancient DNA suggests that the spring-run allele was once abundant in a Northern California habitat that will soon become accessible to fish through a largescale dam removal project, but the researchers report that re-establishment of the spring-run phenotype in this restoration project (and others) will struggle to overcome widespread declines in, or extirpation of, the spring-run phenotype and allele. These results indicate that, without conservation action, human activities can eliminate important adaptive variation as well as the potential to recover it.

Thompson TQ, Bellinger MR, O'Rourke SM, et al. 2019. Anthropogenic habitat alteration leads to rapid loss of adaptive variation and restoration potential in wild salmon populations. P Natl Acad Sci USA 116(1):177-86. https://doi.org/10.1073/pnas.1811559115

\section{Large amounts of organic carbon stored in deep alluvial soils}

A ctive floodplains are thought capable of storAing large amounts of organic carbon in subsoils that, originating from erosion within the floodplain's watershed, were subsequently deposited in the floodplain. Researchers including Kristin Steger, then of the Department of Viticulture and Enology at UC Davis, and Joshua Viers of the School of Engineering at UC

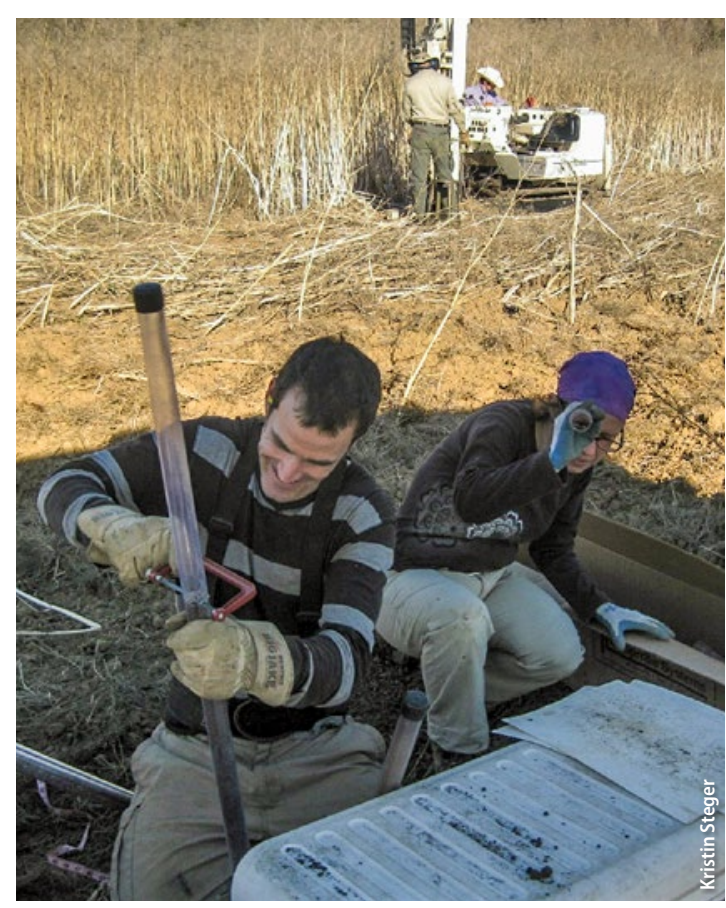

Results from a study conducted in a floodplain of the lower Cosumnes River suggest that alluvial soils in floodplains store large amounts of carbon for which global carbon models do not account. 
Merced conducted a study to assess organic carbon pools in alluvial floodplain soils that are affected by human-induced changes in floodplain deposition and land use. The researchers took and evaluated 33 soil cores in the lower Cosumnes River - 23 soil cores 3 meters in depth and 10 cores 7 meters in depth. They estimate that approximately $59 \%$ of the organic carbon in the 7-meter profiles was stored in the top 2 meters. Their data indicates that use of arable land has already altered the stable isotopic signature in the top meter. The researchers' radiocarbon dating and their analysis of soil mercury content indicate that overlaying soils in the cores underwent a substantial sedimentation phase as a result of upstream hydraulic gold mining beginning in the 1850s. The authors report that deep alluvial soils in floodplains store large amounts of organic carbon for which global carbon models do not account, representing a shortcoming in our understanding of human-induced interference in carbon cycling.

Steger K, Fiener P, Marvin-DiPasquale M, et al. 2019. Human-induced and natural carbon storage in floodplains of the Central Valley of California. Sci Total Environ 651(1):851-8. https://doi.org/10.1016/j. scitotenv.2018.09.205

\section{Emissions from California sheep production quantified}

A mid concerns over animal agriculture's contribuAtions to global warming, the greenhouse gas emissions of U.S. livestock production systems have been the subject of considerable research. The environmental impact of U.S. sheep production, however, had never been studied through life cycle assessments and with a case study methodology. A team of researchers from the Department of Animal Science at UC Davis, UCCE and the UC ANR Hopland Research and Extension Center conducted a life cycle assessment that analyzed five meat sheep production systems in California, the nation's leading sheep producer. For the research - the first research project specifically to examine the carbon footprint of the California sheep industry and to consider both wool and meat production across the state's varied sheep production systems - team members derived data from producer interviews and from existing literature, analyzing it in terms of flock outputs such as market lamb meat, breeding stock, two-day-old lambs, culled adult meat and wool. They utilized four methane prediction models, including two prominent models associated with the Intergovernmental Panel on Climate Change. They found that, across all case studies, enteric methane production was the largest single source of greenhouse gas emissions, accounting for an average of $72 \%$ of total emissions. Emissions from feed production - primarily emissions associated with manure and credited to feed - averaged $22 \%$ of total emissions. The researchers also studied water usage in sheep production systems, determining that whole-ranch water usage ranged from 2.1 to 44.8 metric tons per kilogram (252 to 5,380 gallons per pound)

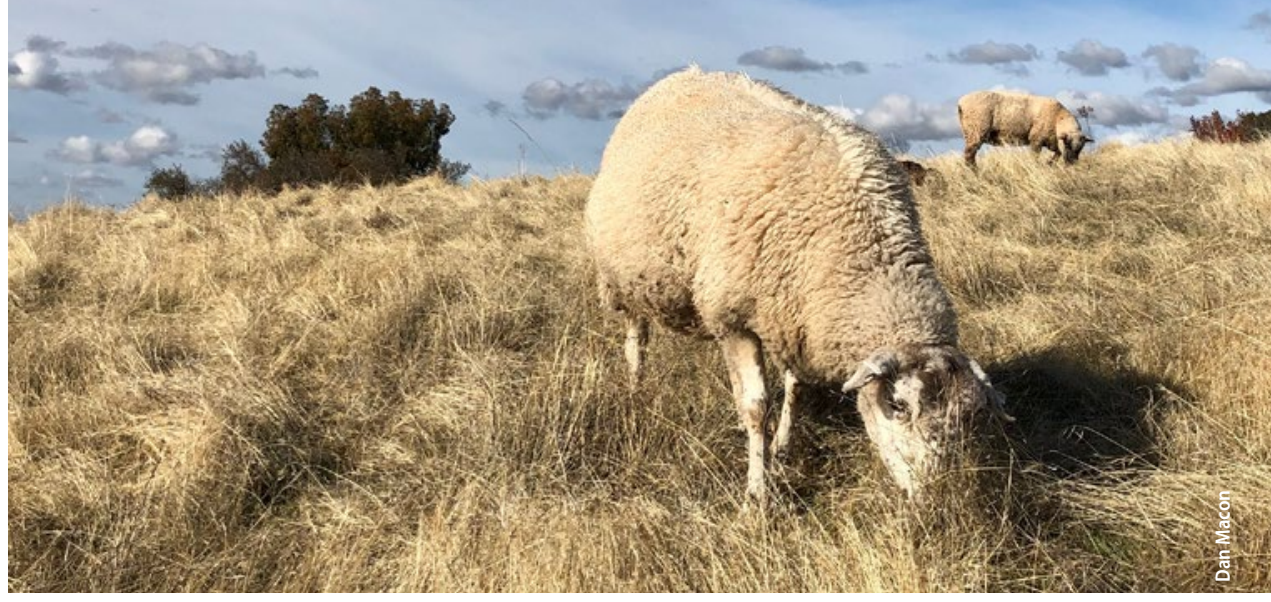

of market lamb, with the usage credited almost entirely to feed production. Overall, the results accorded with similar studies focused on meat sheep production systems in the United Kingdom, as well as with studies of California cattle raised using practices similar to those examined in the researchers' work.

Dougherty HC, Oltjen JW, Mitloehner FM, et al. 2019. Carbon and blue water footprints of California sheep production. J Anim Sci 97(2):94561. https://doi.org/10.1093/jas/sky442

\section{Cover cropping and no-till can benefit soils' fungal composition}

To determine the carbon footprint of California's sheep industry, a team of UC Davis and UCCE researchers conducted a life cycle assessment of five meat sheep production systems. They found that enteric methane production accounted for an average of $72 \%$ of total emissions, and feed production an average of $22 \%$.

$\mathrm{n}$ row-crop and grassland soils, fungi provide essential ecosystem services. Saprotrophic fungi play important roles in nutrient mobilization, organic matter decomposition, carbon cycling and creation of soil structure. Symbiotrophic fungi expand the surface
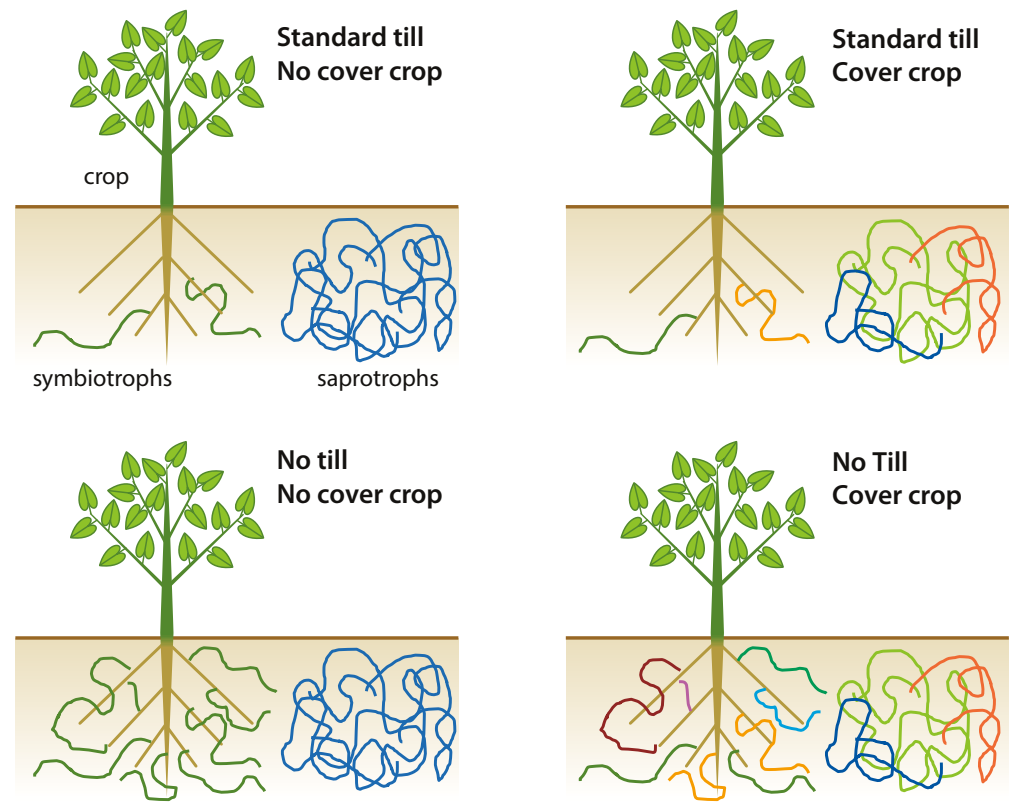

Effect of no-till and cover cropping on relative abundance and diversity of symbiotrophic and saprotrophic fungi. No till leads to higher proportion of symbiotrophs while cover crops lead to increased fungal diversity. 


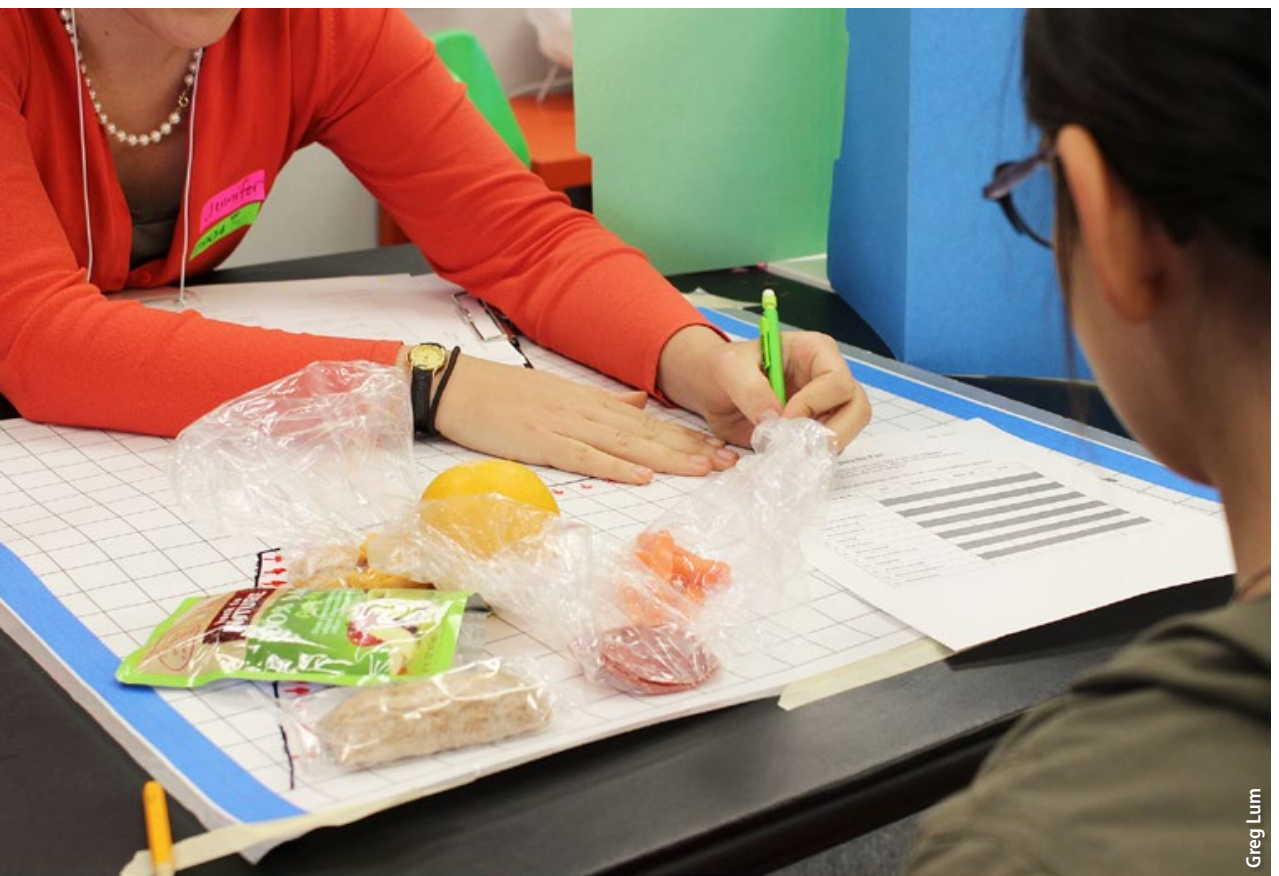

Researchers assessed home-packed lunches over a school week, using a digital imaging procedure to determine how often, and how many servings of, fruits and vegetables were packed in school lunches.

\section{Factors related to nutrition in home-packed lunches investigated}

1 any children in the United States eat fewer servings of fruit and vegetables than dietary experts recommend. Such dietary behaviors often persist into adulthood and are associated with development of chronic disease. As children enter the late-elementary school years, they consume increasing proportions of their nutrition outside the home, including during lunchtime at school. Research indicates that roughly $30 \%$ to $40 \%$ of students eat lunches packed at home and that the nutritional quality of home-packed lunches is lower than that of lunches provided at school. Little research, however, has focused on factors associated with the nutritional quality of home-packed lunches. A team of UC Davis researchers - including Carolyn Sutter of the Department of Human Ecology (now at the University of Illinois), Jennifer Taylor of the Graduate Group in Nutritional Biology (now at UC San Diego), and Lenna Ontai and Adrienne Nishina of the Department of Human Ecology - conducted a study to determine whether parents with greater nutritional knowledge pack lunches containing more fruit and vegetables; whether authoritative parenting (a parenting style in which parents are both demanding of children and responsive to their needs) is related to how many servings of fruit and vegetables are packed; and whether family financial stress and children's involvement in packing lunches are related to the servings of fruit and vegetables provided. Parents recruited for the research project completed questionnaires about their parenting approaches and family situations and completed daily reports about children's level of involvement in lunch packing. Researchers assessed home-packed lunches over a school week, using a digital imaging procedure to determine how often, and how many servings of, fruits and vegetables were packed in school lunches. Researchers applied statistical techniques to the data they derived, finding that families with higher levels of nutrition knowledge tended to pack more fruit over the course of the week; authoritative parenting was associated with more servings of vegetables across the week; family financial stress was associated with higher rates of never packing vegetables; and that children's involvement in lunch decisions was associated with packing more fruit and vegetables across the week. The researchers' findings suggest that home-packed lunches might contain more fruits and vegetables if outreach programs provided nutrition information to parents and encouraged children to involve themselves in lunch-packing decisions.

Sutter C, Taylor JC, Nishina A, Ontai LL. 2018. Parental and family predictors of fruits and vegetables in elementary school children's homepacked lunches across a school week. Appetite 133:423-32. https://doi. org/10.1016/j.appet.2018.12.003 


\section{UC experts can lead on carbon dioxide removal}

\section{Through technology demonstration and policy engagement, UC ANR specialists, advisors and AES faculty can support California's ambitions to remove $\mathrm{CO}_{2}$ from the atmosphere.}

Daniel L. Sanchez, Assistant Cooperative Extension Specialist, Department of Environmental Science, Policy, and Management, UC Berkeley Benjamin Z. Houlton, Director, UC Davis John Muir Institute of the Environment

Whendee Silver, Professor, Department of Environmental Science, Policy, and Management, UC Berkeley

Online: https://doi.org/10.3733/ ca.2019a0009

\begin{abstract}
arbon dioxide removal (CDR) technologies, also known as negative emissions technologies, appear critical to achieving California's ambitious climate change mitigation goals (Cameron et al. 2017). Negative carbon dioxide $\left(\mathrm{CO}_{2}\right)$ emissions cannot be achieved by reducing greenhouse gas (GHG) emissions alone; rather, both emissions reductions and pathways to atmospheric $\mathrm{CO}_{2}$ extraction are needed to achieve this desired outcome. Yet CDR technologies lack both technical and commercial maturity, and are not yet deployed at industrial scales. In response, numerous
\end{abstract}

state government and nongovernmental organizations in California have taken early steps to support research, development and demonstration (RD\&D) of carbon removal (California Air Resources Board et al. 2018; Forest Climate Action Team 2018).

There are two general approaches to CDR, biological and engineered (fig. 1). Biological approaches enhance or manipulate natural sinks for $\mathrm{CO}_{2}$ to store more carbon, typically on land. Engineered approaches apply chemical and physical processes to capture and reliably convert or store $\mathrm{CO}_{2}$ (Sanchez, Amador, et al. 2018).

\section{B | O L O G I C A L}

E N G I N E ERE D

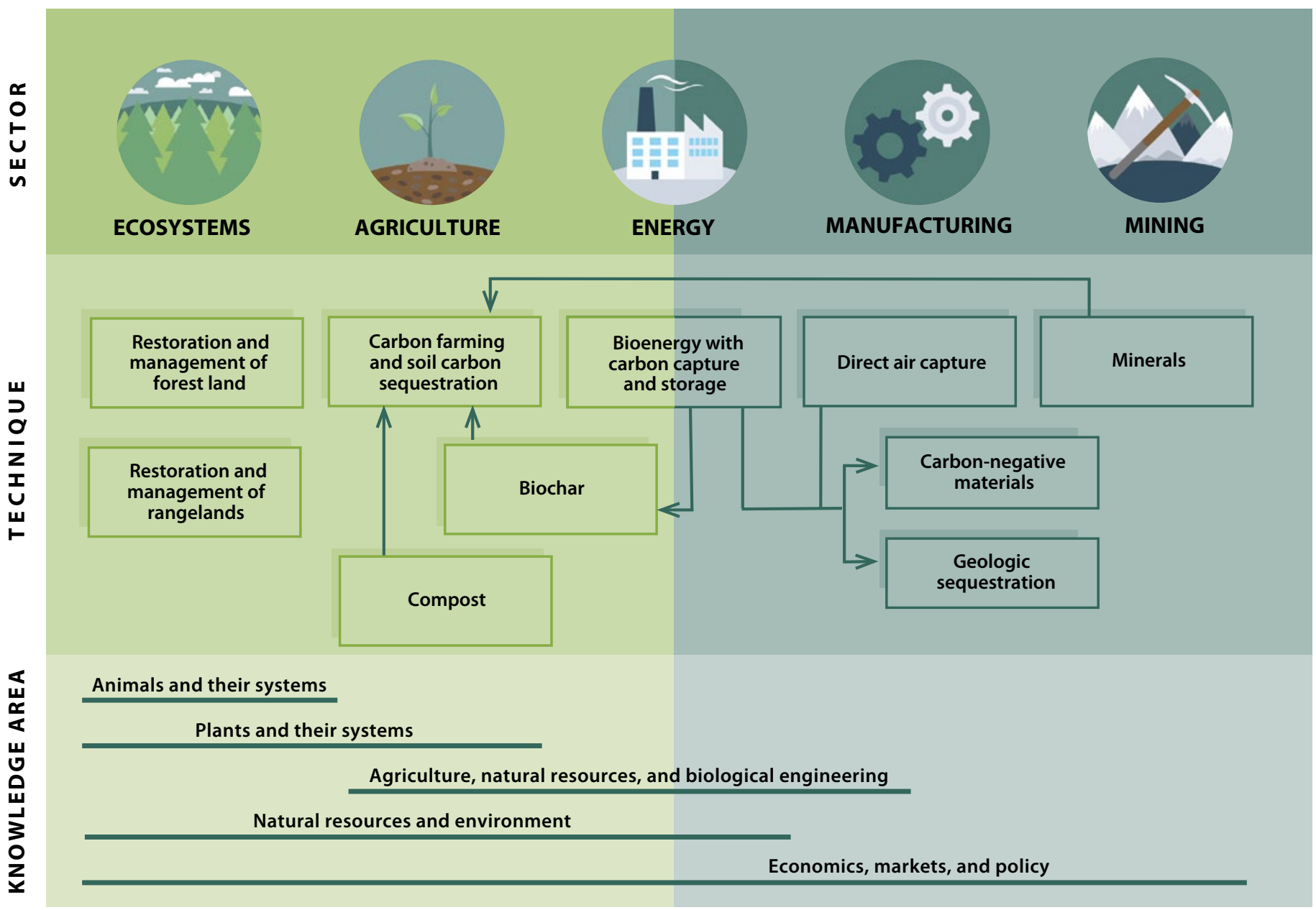

FIG. 1. Sectors, techniques and UC ANR knowledge areas relevant to carbon removal technologies. Knowledge areas drawn from UC ANR's Taxonomy and Personnel System. Adapted from Sanchez, Amador, et al. 2018. 
Biological and engineered approaches to $\mathrm{CO}_{2}$ removal can be deployed alongside other climate change responses to reduce emissions, avoid climate impacts, and promote economic development within

\section{Overview of the Working Lands Innovation Center (WLIC)}

Partners: University of California, Davis; University of California, Berkeley; California State University, East Bay; Lawrence Berkeley National Laboratory; University of California, Merced

Funding: $\$ 4.7$ million

Objective: To scale and sustain $\mathrm{CO}_{2}$ capture and $\mathrm{GHG}$ emissions reductions by deploying a suite of cutting-edge soil amendment technologies, driving substantial co-benefits for California growers, ranchers, tribes, communities, the economy and environment. This project will increase understanding of the mechanisms and potential for carbon sequestration in soil.

Research: WLIC's research is focused on three technologies to capture $\mathrm{CO}_{2}$ with co-benefits: rock amendments in cropland and rangelands, compost applications to cropland and rangeland soil, and demonstration of combinations of compost, rocks and biochar. WLIC will also conduct geospatial model analysis to identify best practices for scaling carbon removal statewide. These soil amendment technologies have not yet been tested together across the state.

Benefits: WLIC's demonstrations will (i) maintain and protect agricultural economy in rural areas; (ii) promote opportunities for tribal nations through collaborative partnerships; (iii) create cleaner air and water in the Central Valley and Imperial Valley; (iv) redesign organic waste streams, converting problems into solutions; (v) restore soil health and protect the environment; (vi) enhance agricultural workforce development; (vii) increase the affordability of healthy food options; (viii) create opportunities for ranchers and farmers to financially benefit from soil restoration practices and GHG reductions; and (ix) develop new business opportunities in the area of soil amendment production, distribution and innovation.

Engagement: Work with commercial partners (Almond Board of California, compost and biochar producers), landowners across California (commercial and family farmers and ranchers), the USDA, UC Agriculture and Natural Resources, small business development (Larta Institute), tribes and the American Carbon Registry to translate science findings into action, and scale technologies within and outside of California. Annual and sub-annual farmer showcase events will highlight opportunities for farmers and ranchers to engage in research and deploy technologies.
California. In this way, CDR offers an array of useful co-benefits for the economy, people and the planet.

UC Cooperative Extension (UCCE) researchers and Agricultural Experiment Station (AES)-appointed faculty hold considerable expertise in carbon removal technologies, whether in working lands management, carbon sequestration, land restoration or forest products (fig. 1). They form an essential go-between from basic research to applied outcomes, working with faculty and student researchers to create material gains for citizens and society. Moreover, UCCE's transdisciplinary approach to applied research, outreach and engagement can help commercialize CDR, positioning California for continued technology leadership. When combined with UC's world-leading education and research community and system-wide initiatives in climate neutrality, UCCE has the potential to catalyze research discoveries into negative emissions. Here, we provide an overview of existing and potential technology demonstration and policy engagement activities within UCCE relevant to carbon removal in California. We argue that specialists and advisors have a unique and unprecedented role in supporting California's ambitions to remove $\mathrm{CO}_{2}$ from the air.

\section{Leadership in development and deployment}

UCCE has a long history of commercializing and disseminating new technologies to farmers, ranchers and natural resource managers (Humiston 2015). These include technologies that enhance export competitiveness, environmental sustainability and resilience to extreme weather while promoting economic opportunities for farmers, ranchers and rural communities. California has long benefited from these successful new industries, healthy ecosystems and sustainably managed landscapes. CDR deployment can benefit from UCCE's wide array of external partners, projects and resources built over the last century.

UCCE plays an essential role in the "innovation ecosystem" for CDR. Innovation is commonly conceptualized as a process involving invention, innovation and diffusion, where users produce more or better outputs from the same inputs (Nemet et al. 2018). These performance improvements and cost reductions can generate better outcomes, such as increased $\mathrm{CO}_{2}$ removal, reduced environmental side effects, and greater public acceptance. As innovation progresses from research, to demonstration, scale up, niche markets and large-scale deployment, UCCE can interface with the most relevant stakeholders supporting implementation. These extension audiences include academics, entrepreneurs, resource managers, technology developers, policymakers and community members (fig. 2).

$\mathrm{CO}_{2}$ removal also aligns with an emerging strategic priority within UCCE: mobilizing to address the threat of climate change (Grantham et al. 2017). Since 2015, UC Agriculture and Natural Resources (UC ANR) has supported a climate change program team, which is building capacity within UCCE to better address climate change

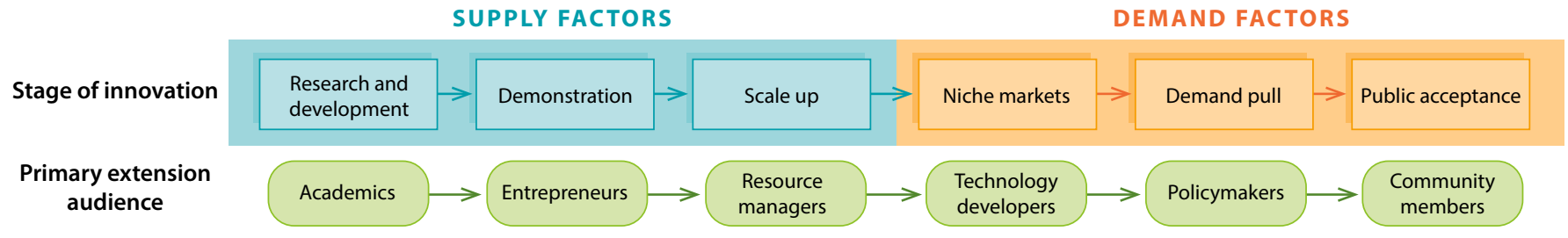

FIG. 2. Stages of innovation and primary extension audiences. Supply factors reduce the costs of innovation through education and research. Demand factors increase the returns to innovation by increasing the demand for new technologies. Adapted from Nemet et al. 2018. 
impacts and adaptation challenges. This team, which consists of advisors and specialists across the state, is working to identify the tools, resources and information that UC ANR extension personnel need to engage more effectively with climate change.

Recently, UCCE has taken several steps to advance research and outreach on carbon removal in California. Taken together, these projects and initiatives demonstrate UCCE's unique ability to advance research and outreach around CDR. They include:

- C4S Working Lands Innovation Center Catalyzing Negative Carbon Emissions: A center to scale and sustain $\mathrm{CO}_{2}$ capture and GHG emissions reductions by deploying a suite of cuttingedge soil amendment technologies, including compost, pulverized rock and biochar. This project will increase understanding of the mechanisms and potential for carbon sequestration in soil, while driving substantial co-benefits for California growers, ranchers, tribes, communities, the economy and environment (see sidebar). This innovation ecosystem, borne from the California Collaborative for Climate Change Solutions (C4S), was recently awarded $\$ 4.7$ million by the California Strategic Growth Council via revenues generated from the state's cap and trade fund.

- Carbon farming: UCCE Sonoma County and Marin County have worked with local resource conservation districts to support carbon farm planning, a whole farm approach to optimizing carbon capture on working landscapes. Working with landowners, advisors developed plans for grazing management, compost application, soil sampling and impact assessment. Ultimately, landowners were able to increase soil carbon by implementing Natural Resources Conservation Service practices and tools, thereby removing $\mathrm{CO}_{2}$ from the atmosphere. UCCE Marin County has supported additional projects that sequester $\mathrm{CO}_{2}$ through riparian restoration.

\section{- Joint Institute for Wood Products Innovation:}

This UC-CSU joint institute will provide guidance, research and analysis to support expansion of the forest products sector in California in a manner that increases economic drivers for healthy forests. The work of the Institute will support sustainability, forest resilience, long-term carbon storage and local economies, and serve as a center for analysis, testing and outreach in California. The Joint Institute was established by the California Board of Forestry and Fire Protection pursuant to Executive Order B-52-18.

Each of the projects is transdisciplinary, applied and collaborative - three hallmarks of UCCE activities.

Moving forward, UCCE can continue to fill this unique role in state-sponsored research and demonstration programs.

\begin{tabular}{|c|c|c|c|c|}
\hline Overarching policies & E.O. B-55-18 & $\begin{array}{l}\text { NWL implementa } \\
\text { tion plan }\end{array}$ & $\begin{array}{l}\text { Strategic Growth } \\
\text { Council funding }\end{array}$ & S.B. 100 \\
\hline $\begin{array}{l}\text { Technology } \\
\text { pathways }\end{array}$ & $\begin{array}{l}\text { Low-carbon } \\
\text { fuels standard }\end{array}$ & Buy Clean California & & \\
\hline Biomass utilization & $\begin{array}{l}\text { Renewable } \\
\text { natural gas } \\
\text { procurement }\end{array}$ & $\begin{array}{l}\text { Wood product } \\
\text { innovation }\end{array}$ & $\begin{array}{l}\text { Biomass-to-power } \\
\text { mandates }\end{array}$ & \\
\hline Natural pathways & $\begin{array}{l}\text { Healthy Soils } \\
\text { Initiative }\end{array}$ & Offset programs & $\begin{array}{l}\text { Land restoration \& } \\
\text { conservation }\end{array}$ & $\begin{array}{l}2030 \text { NWL } \\
\text { goals }\end{array}$ \\
\hline \multicolumn{5}{|l|}{ Federal policies } \\
\hline & Tax policy & $\begin{array}{l}\text { Renewable Fuel } \\
\text { Standard }\end{array}$ & Farm Bill & $\begin{array}{l}\text { R\&D } \\
\text { policy }\end{array}$ \\
\hline
\end{tabular}

FIG. 3. Taxonomy of CDR policies in California and supportive federal policy.

\section{Implementing and improving policy}

UCCE can also bring its vast technical and relational knowledge to bear on policy for CDR (Gupta et al. 2019). Extension can provide multiple services to the policy process: technical expertise, objectivity, partnership building, stakeholder-oriented research, and community empowerment. UCCE's ability to foster deliberative dialogue within diverse communities can build experience and trust in CDR approaches.

To date, California has developed numerous policies that can support carbon removal technologies (fig. 3). These span high-level climate goals, research and development, purchasing mandates, sectoral GHG standards, carbon offsets, technology demonstration and land conservation programs. Below, we briefly highlight several policies that hold promise for promoting CDR.

\section{High-level goals}

\section{- Executive Order B-55-18 to Achieve Carbon}

Neutrality sets a new statewide goal to "achieve carbon neutrality as soon as possible, and no later than 2045, and achieve and maintain net negative emissions thereafter." While this goal has not been codified into law by the legislature, executive orders such as this one have historically been the first step towards legally binding policy.

- 2030 Natural and Working Lands Climate Change Implementation Plan poses an increase in state-led conservation, restoration and management activities from two to five times above current levels. The plan acknowledges that state efforts to conserve, restore and manage natural and working lands play a pivotal role in achieving deep GHG reductions.

- S.B. 100 sets an ambitious goal for $100 \%$ of California's electricity to be supplied by renewable energy and zero-carbon resources, including generators with carbon capture and sequestration. 


\section{Technology pathways}

- Low Carbon Fuel Standard (LCFS) carbon capture and storage protocol enables carbon capture and sequestration projects associated with fuel production to access low-carbon fuel standard credits, which provide financial incentive for lower-carbon fuels. Carbon capture projects are eligible regardless of where the projects are located. Direct air capture technologies are also eligible to participate.

- Buy Clean California (A.B. 262) calls for California state government to procure low-carbon goods. The program applies to carbon steel rebar, flat glass, mineral wool board insulation and structural steel, but not yet to cement and other harvested wood products that can store or sequester $\mathrm{CO}_{2}$.

- Biopower and renewable natural gas procurement programs set mandates for procurement of electricity from high-hazard waste biomass sources (E-4805), small-scale biomass power plants (E4922) and biomethane (S.B. 1440). Many of these technologies can remove $\mathrm{CO}_{2}$ from the atmosphere.

\section{R\&D policy}

- Strategic Growth Council innovation funding has been directed towards natural and technological carbon removal solutions.

- California Energy Commission energy RD\&D programs advance innovation on low-carbon fuels and electricity. Their work has supported research and analysis on carbon-negative energy systems, biogas, biochar and other CDR technologies.

- Joint Institute for Wood Products Innovation, established by the Board of Forestry, advances development of new wood products, which can sequester $\mathrm{CO}_{2}$ and drive ecologically beneficial forest management.

\section{Ecological pathways}

- Healthy Soils Initiative provides technical assistance and grants for farmers and ranchers to adopt soil carbon sequestering practices and measurement and verification plans.

- California Climate Investments Forest Health Grant Program restores forest health to reduce GHGs, promote the longterm storage of carbon in forest trees, minimize the loss of forest carbon from severe wildfire and further the state's climate change goals.

- U.S. and tropical forest programs provide carbon offsets from the state's cap and trade system for practices that increase in-forest carbon storage or reduce tropical deforestation, respectively.

- Sustainable Agricultural Lands Conservation Program has provided over \$120 million in grant funding to reduce GHGs associated with land conversion.

Finally, California-based efforts can interface with federal CDR policy. These include tax credits for carbon sequestration (Section 45Q), the federal Renewable Fuels Standard, agriculture policies set in the Farm Bill, and research, development and demonstration (RD\&D) programs for agriculture and energy projects. For instance, operators of biorefineries and anaerobic digesters that capture and sequester their $\mathrm{CO}_{2}$ emissions can qualify both for federal tax credits and the LCFS, should they sell their low-carbon fuels in California (Sanchez, Johnson, et al. 2018).
As California continues to innovate in CDR policy, UCCE can fill multiple roles. First, it can work with AES-appointed faculty and other researchers in the UCs and UC national labs to test, perfect and demonstrate new research breakthroughs in CDR. Second, it can contribute its own expertise to develop new policies, particularly those that leverage California's ecosystems for carbon removal. Third, it can help spread information about existing incentives to landowners and resource managers considering CDR. Finally, it can offer feedback to policymakers on existing policies based both on policy-relevant research and on the experiences of rural Californians. These roles span UCCE's unique mix of technical and relational knowledge.

\section{A vision for Cooperative Extension}

UCCE efforts to develop and deploy CDR technologies have the opportunity to scale across and outside of California. UC is an active participant in the $\mathrm{C} 4 \mathrm{~S}$, which aims to accelerate the translation of research into practical climate solutions at the national and global level. C4S brings together UC, CSU, UC national labs, Stanford, Caltech and USC, and has prioritized development of CDR technologies. Outside of the state, UC has launched the University Climate Change Coalition (UC3), a coalition of leading North American research universities that will prototype a collaborative model designed to help local communities achieve their climate goals. UC3 now consists of 26 university partners outside California. UC3 provides a way to scale the UC's Carbon Neutrality Initiative to other jurisdictions, both domestically and abroad. Given its expertise and support within and beyond the state, UCCE is already a leader in creating practical winwins toward the carbon-negative economy, with the potential to do even more through these and other efforts in the future. CA

\section{References}

California Air Resources Board, California Environmental Protection Agency, California Department of Food and Agricul ture, et al. 2018. California 2030 Natural and Working Lands Climate Change Implementation Plan Concept Paper.

Cameron DR, Marvin DC, Remucal JM, et al. 2017. Ecosystem management and land conservation can substantially contribute to California's climate mitigation goals. Proc Natl Acad Sci 114:12833-38. https://doi.org/10.1073/ pnas. 1707811114

Forest Climate Action Team. 2018. Forest Carbon Plan: managing our forest landscapes in a changing climate.

Grantham T, Kearns F, Kocher S, et al. 2017. Building climate change resilience in California through UC Cooperative Extension. Calif Agr 71:197-200. https:// doi.org/10.3733/ca.2017a0045
Gupta C, Campbell D, Cole-Weiss A. 2019. Cooperative Extension can better frame its value by emphasizing policy relationships. Calif Agr 73:11-18. https:// doi.org/10.3733/ca.2018a0040

Humiston G. 2015. UC ANR: The original incubator. Calif Agr 69:206-7. https:// doi.org/10.3733/ca.v069n04p206

Nemet GF, Callaghan MW, Creutzig F, et al. 2018. Negative emissions-Part 3: Innovation and upscaling. Environ Res Lett 13:063003. https://doi org/10.1088/1748-9326/aabff4

Sanchez DL, Amador G, Funk J, et al. 2018. Federal research, development, and demonstration priorities for carbon dioxide removal in the United States. Environ Res Lett 13:015005. https://doi. org/10.1088/1748-9326/aaa08f

Sanchez DL, Johnson N, McCoy ST et al. 2018. Near-term deployment of carbon capture and sequestration from biorefineries in the United States. Proc Natl Acad Sci 115:4875-80. https://doi. org/10.1073/pnas.1719695115 


\section{Ratio of farmworkers to farm jobs in California increased to 2.3 in 2016}

The ratio of workers to average jobs is increasing, moving the farm labor market away from what public policy has long tried to achieve, a farm labor market with fewer workers who are employed most of the year.

by Philip Martin, Brandon Hooker and Marc Stockton

$\mathrm{T}$ he ratio of workers to full-time-equivalent (FTE) jobs in an industry is one important measure of the nature of the labor market. The ratio is high if there is seasonality and high rates of turnover. Over the last several decades, seasonal industries such as construction have restructured in ways that have reduced the ratio of workers to FTE jobs.

To evaluate this aspect of the agricultural labor market in California, we analyzed data collected by the California Employment Development Department (EDD) in 2016 and compared key findings with our earlier analysis of similar data from 2015.

\section{Farm jobs and farmworkers}

How many people work for wages in California agriculture? Answering this question has been surprisingly difficult, largely because most farm jobs are seasonal, lasting from several weeks to several months, and there is high turnover, with many workers trying farm work and soon quitting.

\section{Abstract}

California Employment Development Department data suggest that almost 5\% of California's workers were employed in agriculture, in 2016. In that year, monthly average employment in agriculture was 425,400, but the number of workers with at least one job in agriculture was 2.3 times that figure, 989,500. The number of hired farmworkers, including supervisors and office personnel, rose almost 20\% between 2015 and 2016. Most workers employed in agriculture do not work year-round, so there is a gap between the average earnings of a full-time equivalent job in agriculture $(\$ 32,316$ in 2016$)$ and the average earnings of actual agricultural workers $(\$ 19,800$ in 2016). This gap was widest for the third of all farmworkers employed by farm labor contractors (FLCs). Over half of the workers whose maximum earnings were in agriculture had only one farm job. Almost $20 \%$ of farmworkers received unemployment insurance benefits in 2016, including half of those whose maximum earnings were in logging and cotton ginning. Public policy has long favored a farm labor market in which most workers are employed yearround; these data indicate that the farm labor market in California is, on average, heading in the opposite direction.

Online: https://doi.org/10.3733/ca.2019a0002 
EDD publishes data on farm employment for the payroll period that includes the 12th of the month; in 2016, EDD data indicated that average monthly farm employment was 425,400 . This 425,000 average is not a count of all individuals employed in agriculture, because some workers were employed but not during the payroll period that includes the 12th of the month. Including these not-on-payroll during the 12th of the month workers provides a count of all workers employed in agriculture.

EDD does not report the total number of unique farmworkers. This article fills this information gap, finding that there were about 2.3 workers for each average or FTE job.

All California employers who pay $\$ 100$ or more in quarterly wages are required to report each quarter their employees for the payroll period that includes the 12th of the month and the wages paid to all workers during the quarter, and to submit appropriate unemployment insurance (UI) taxes. In 2016, some 16,150 California agricultural establishments - North American Industry Classification System (NAICS) code 11, including farming, forestry, fishing and hunting - hired a monthly average 425,400 workers and paid them a total of $\$ 13.7$ billion. The data also show that over the past decade, the number of agricultural establishments fell over $10 \%$, average employment rose over $10 \%$, and total wages rose $50 \%$.

Over $99 \%$ of the agricultural establishments that report employment are farms or firms supporting farms such as farm labor contractors (FLCs). There are very few workers who had their maximum earnings in forestry, fishing and hunting, only $0.8 \%$. We use "farmworker" in this paper to mean all workers employed in agriculture, including supervisors and accountants

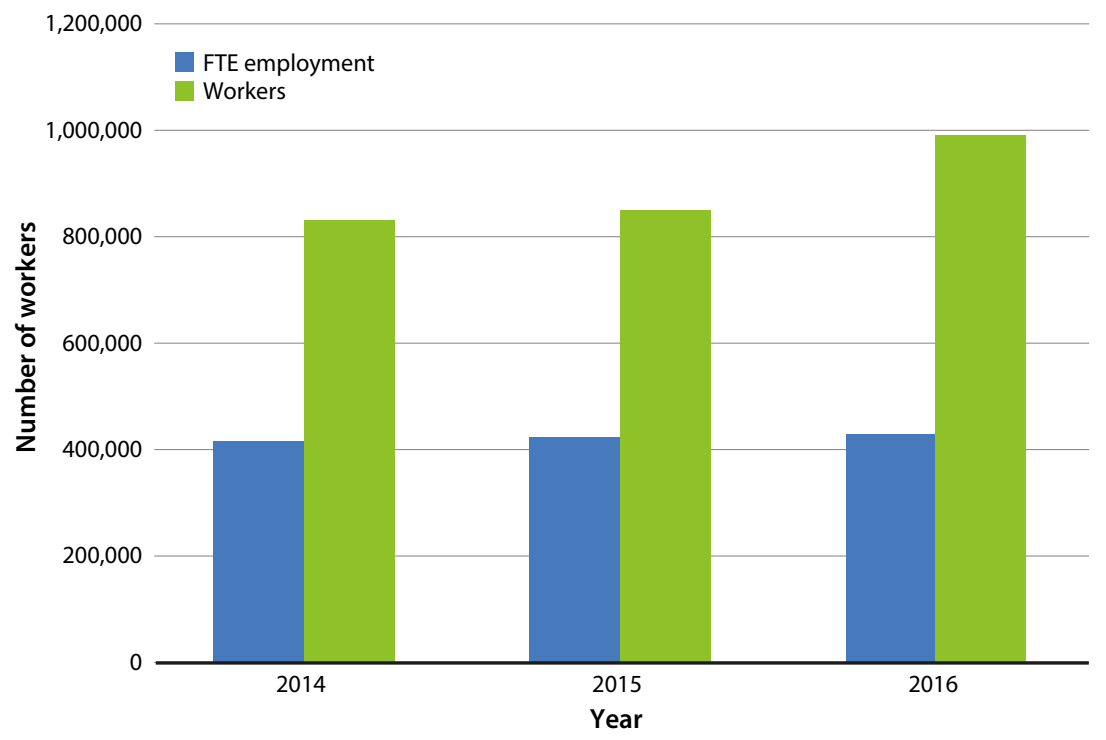

FIG. 1. Average FTE employment versus actual number of workers in California agriculture, 2014-2016. employed by farms, acknowledging that a few are employed in forestry, fishing and hunting.

The average monthly employment of 425,400 reported by EDD represents 12 monthly snapshots of persons on the payroll during the payroll period that includes the 12 th of the month. As such, it is a measure of the number of FTE positions in agriculture in California. Employers do not report hours of work, so some of the workers on the payroll may have worked full time and others part time.

The $\$ 13.7$ billion total wage figure represents payments to all workers, including those who were employed at other times of the month but not during the payroll period that includes the 12 th. Dividing $\$ 13.7$ billion by 425,400 gives $\$ 32,316$, which would be the average annual salary of a full-time farmworker. However, since many farmworkers are employed fewer than 2,080 hours a year, average earnings for the individuals who do farm work are significantly less; our analysis of earnings by individual workers (see below) indicates that the average earnings from all jobs of all workers with at least one job in California agriculture was $\$ 19,762$ in 2016.

To investigate this difference, we captured all workers reported by an agricultural employer, tallying a total of 989,500 individual workers in 2016. This process allows us to compare the total number of farmworkers with the monthly average number of farm jobs. Figure 1 shows that this ratio has been rising from two workers per average job in 2014 and 2015 to 2.3 workers per average job in 2016, suggesting more workers tried farm work.

The analysis is based on Social Security numbers (SSNs) reported by agricultural employers when paying UI taxes. Because we had data on all of the California jobs (both farm jobs and other jobs) associated with each individual SSN reported by an agricultural employer, we could assign each worker (that is, each SSN) to the NAICS code in which he or she had their highest earnings. This procedure identified 804,200 workers who worked primarily in agriculture ("primary farmworkers" hereafter). This total includes $\mathrm{H}-2 \mathrm{~A}$ guest workers whose highest earnings were from an agricultural employer. Primary farmworkers accounted for over $80 \%$ of all workers with at least one job in California agriculture. Another 185,000 workers, or almost $20 \%$ of all agricultural workers, had at least one job with an agricultural employer but earned more from a nonfarm employer.

EDD does not verify SSNs submitted by employers unless the worker applies for UI, which $20 \%$ of agricultural workers did in 2016. We do not know how many workers used multiple SSNs in 2016 and how many times several workers shared one SSN, but we did drop from the analysis SSNs (and their associated earnings) used by more than 10 employers, which eliminated one-tenth of $1 \%$ of SSNs. 
TABLE 1. FTE and primary farmworker average annual pay, 2016

\begin{tabular}{|c|c|c|c|c|c|c|}
\hline & & $\begin{array}{l}\text { Share of ag FTE } \\
\text { employment }\end{array}$ & $\begin{array}{c}\text { Average FTE } \\
\text { pay }\end{array}$ & $\begin{array}{c}\text { Average earnings of } \\
\text { primary workers }\end{array}$ & $\begin{array}{l}\text { Primary workers } \\
\text { share of FTE pay }\end{array}$ & $\begin{array}{l}\text { Implied hourly wage } \\
\text { for } 2,080 \text { hours }\end{array}$ \\
\hline & & $\%$ & $\$$ & $\$$ & $\%$ & $\$$ \\
\hline NAICS 11 & All ag & 100 & 32,316 & 16,142 & 50 & 15.54 \\
\hline NAICS 111 & Crops & 41 & 34,411 & 20,540 & 60 & 16.54 \\
\hline NAICS1112 & Vegetables & 8 & 39,809 & 26,092 & 66 & 19.14 \\
\hline NAICS1113 & Fruits & 23 & 31,846 & 16,900 & 53 & 15.31 \\
\hline NAICS1114 & Nursery & 6 & 35,250 & 27,124 & 77 & 16.95 \\
\hline NAICS 112 & Animals & 7 & 37,372 & 30,989 & 83 & 17.97 \\
\hline NAICS 112120 & Dairy & 4 & 36,864 & 31,433 & 85 & 17.72 \\
\hline NAICS 1151 & Crop support & 51 & 29,956 & 12,297 & 41 & 14.40 \\
\hline NAICS 115113 & Machine harvesting & 2 & 35,457 & 17,571 & 50 & 17.05 \\
\hline NAICS 115114 & $\begin{array}{l}\text { Postharvest crop } \\
\text { services }\end{array}$ & 10 & 40,846 & 23,485 & 57 & 19.64 \\
\hline NAICS 115115 & FLCs & 34 & 24,589 & 9,026 & 37 & 11.82 \\
\hline
\end{tabular}

$\mathrm{FLC}=$ farm labor contractor; $\mathrm{FTE}$ = full-time equivalent.

Source: EDD analysis of unemployment insurance payroll tax data.

\section{FTE and actual earnings}

Table 1 compares the earnings of a FTE worker with the actual earnings of primary farmworkers by commodity in California in 2016. For example, an FTE primary farmworker would have earned $\$ 32,316$ from all farm and nonfarm jobs ("All ag" category), but the average annual pay of primary farmworkers from all jobs was $\$ 16,142$, half as much. The implied hourly wage of an FTE worker who was employed 2,080 hours was $\$ 15.54$.

California's minimum wage was $\$ 10.00$ an hour in 2016 , so the $\$ 16,142$ earned by primary farmworkers reflects a combination of lower hourly wages and fewer hours or weeks of work (employers do not report hours or weeks worked). A worker employed 2,080 hours in 2016 at the $\$ 10.00$ minimum wage would have earned $\$ 20,800$. Farmers reported to USDA National Agricultural Statistical Service that the average earnings of the workers they hired directly were $\$ 13.81$ an hour in 2016 , so a primary farmworker earning $\$ 16,142$ would have worked 1,166 hours at $\$ 13.81$ an hour.

Over $40 \%$ of FTE agricultural workers ( $40 \%$ of the EDD monthly average employment numbers) were hired directly by crop farms (NAICS 111, Crops). They had average annual earnings of $\$ 34,411$ per FTE, equivalent to over $\$ 16.50$ an hour. The actual earnings of workers whose maximum earnings were with crop employers were $\$ 20,540$, or $60 \%$ as much. An FTE position in animal agriculture (NAICS 112, Animals) paid $\$ 37,372$, while workers whose maximum earnings were from animal agriculture averaged $\$ 30,989,83 \%$ as much as a full-time position or FTE job.

More workers are brought to crop farms by nonfarm support service firms such as FLCs than are hired directly by crop farmers. A full-time crop support position via an FLC (NAICS 115115) earned \$24,589 in 2016, equivalent to almost $\$ 12.00$ an hour. However, workers whose maximum earnings were with FLCs earned an average $\$ 9,026$, or $37 \%$ as much, which is equivalent to 900 hours of work at the minimum wage of $\$ 10.00$ an hour or 750 hours at $\$ 12.00$ an hour.

These comparisons of average FTE earnings and average actual earnings for individual workers have three major implications. First, except in animal agriculture, average FTE pay can be a misleading indicator of what most farmworkers earn, since most primary farmworkers earn less than the $\$ 32,300$ or $\$ 15.54$ per hour that is implied by dividing total wages by average employment across all agricultural commodities (NAICS 11).

Second, the largest categories of workers have the lowest wages and the largest gaps between average FTE earnings and actual individual worker average earnings. FLCs employ a third of primary farmworkers, and their employees have the lowest average FTE and average actual worker earnings. Fruits and nuts (NAICS 1113, Fruits) account for almost a quarter of FTE positions and they too have low average FTE and average actual worker earnings.

Third, the ratio of average actual worker earnings to average FTE earnings fell between 2015 and 2016 (Martin et al. 2018). For all workers whose maximum earnings were in agriculture, the ratio of average actual worker earnings to average FTE earnings fell from $58 \%$ to $50 \%$. For workers hired directly by fruit farmers, the ratio fell from $62 \%$ to $53 \%$, and for workers hired by FLCs from $44 \%$ to $37 \%$.

Such falling ratios of FTE to actual earnings suggest that more workers may be trying farm work, but many have relatively low farm earnings. At the same time, some experienced workers could be working more hours. In 2000, a fifth of crop workers were newcomers 
TABLE 2. Farmworkers and farm jobs, 2014-2016

\begin{tabular}{|c|c|c|c|c|c|c|c|}
\hline & $\begin{array}{c}\text { Total } \\
\text { workers }\end{array}$ & One job & Share & $\begin{array}{c}\text { Two } \\
\text { jobs }\end{array}$ & Share & $\begin{array}{c}\text { Three or } \\
\text { more jobs }\end{array}$ & Share \\
\hline 2014 & 829,300 & 499,400 & $60 \%$ & 220,500 & $27 \%$ & 109,400 & $13 \%$ \\
\hline 2015 & 847,600 & 481,700 & $57 \%$ & 217,200 & $26 \%$ & 148,800 & $18 \%$ \\
\hline 2016 & 989,500 & 545,200 & $55 \%$ & 258,500 & $26 \%$ & 185,800 & $19 \%$ \\
\hline
\end{tabular}

Source: EDD.

TABLE 3. Primary farmworkers with one farm job, 2016

\begin{tabular}{|l|l|}
\hline Sheep farming & $92 \%$ \\
\hline Hog and pig farming & $92 \%$ \\
\hline All other grain farming & $83 \%$ \\
\hline $\begin{array}{l}\text { Support activities for animal } \\
\text { production }\end{array}$ & $81 \%$ \\
\hline Mushroom production & $80 \%$ \\
\hline $\begin{array}{l}\text { Dairy cattle and milk } \\
\text { production }\end{array}$ & $75 \%$ \\
\hline Floriculture production & $75 \%$ \\
\hline Nursery and tree production & $73 \%$ \\
\hline Tree nut farming & $71 \%$ \\
\hline Farm labor contractors & $70 \%$ \\
\hline $\begin{array}{l}\text { Other vegetable and melon } \\
\text { farming }\end{array}$ & $67 \%$ \\
\hline Postharvest crop activities & $64 \%$ \\
\hline $\begin{array}{l}\text { Other food crops grown } \\
\text { under cover }\end{array}$ & $64 \%$ \\
\hline Crop harvesting & $64 \%$ \\
\hline Farm management services & $63 \%$ \\
\hline Grape vineyards & $63 \%$ \\
\hline Strawberry farming & $62 \%$ \\
\hline $\begin{array}{l}\text { Orange groves } \\
\text { Fruit and tree nut } \\
\text { combination farming }\end{array}$ & $62 \%$ \\
\hline $\begin{array}{l}\text { Citrus groves } \\
\text { farming }\end{array}$ & $61 \%$ \\
\hline Other noncitrus fruit farming & $60 \%$ \\
\hline Cotton ginning & $59 \%$ \\
\hline fercept strawberry) & $53 \%$ \\
\hline
\end{tabular}

TABLE 4. Farmworkers receiving UI benefits, 2016

\begin{tabular}{|c|c|c|}
\hline $\begin{array}{c}\text { All UI } \\
\text { recipients }\end{array}$ & $\begin{array}{c}\text { Amount } \\
\text { \$million }\end{array}$ & \begin{tabular}{c} 
Average \\
\hline 185,410
\end{tabular} \\
\hline $\begin{array}{c}\text { Number of } \\
\text { workers }\end{array}$ & Amount of benefits \\
\hline 18,031 & $\$ 20-\$ 500$ \\
\hline 155,449 & $\$ 501-\$ 5,000$ \\
\hline 11,743 & $\$ 5,001-\$ 10,000$ \\
\hline
\end{tabular}

$\mathrm{UI}=$ unemployment insurance.

Source: EDD analysis of unemployment insurance payroll tax data.

TABLE 5. Share of workers receiving UI benefits, 2016

\begin{tabular}{|c|c|}
\hline Logging & $47 \%$ \\
\hline Cotton ginning & $45 \%$ \\
\hline $\begin{array}{l}\text { Vegetable and melon } \\
\text { farming }\end{array}$ & $33 \%$ \\
\hline Crop harvesting & $28 \%$ \\
\hline Postharvest crop activities & $28 \%$ \\
\hline $\begin{array}{l}\text { Other vegetable and melon } \\
\text { farming }\end{array}$ & $27 \%$ \\
\hline $\begin{array}{l}\text { Fruit and tree nut } \\
\text { combination farming }\end{array}$ & $25 \%$ \\
\hline Citrus groves & $24 \%$ \\
\hline Grape vineyards & $24 \%$ \\
\hline $\begin{array}{l}\text { Berry (except strawberry) } \\
\text { farming }\end{array}$ & $23 \%$ \\
\hline Farm labor contractors & $19 \%$ \\
\hline Strawberry farming & $15 \%$ \\
\hline Orange groves & $15 \%$ \\
\hline Tree nut farming & $14 \%$ \\
\hline Nursery and tree production & $8 \%$ \\
\hline Floriculture production & $6 \%$ \\
\hline $\begin{array}{l}\text { Dairy cattle and milk } \\
\text { production }\end{array}$ & $4 \%$ \\
\hline Mushroom production & $3 \%$ \\
\hline Sheep farming & $2 \%$ \\
\hline
\end{tabular}

who had entered the country illegally that year; in 2018 fewer than $2 \%$ of crop workers were newcomers who had entered illegally (Gifford Center 2018).

It is possible that workers are concentrated at both ends of the work and earnings spectrum; the averages reported here would not capture such a bimodal distribution.

\section{Migrancy, contractors and other employers}

Farmworkers are still sometimes imagined to be migrants who follow the ripening crops from south to north, changing employers as they follow the sun. In fact, follow-the-crop migration is rare: The National Agricultural Workers Survey finds that fewer than 5\% of workers employed on California crop farms have two farm employers at least 75 miles apart. However, the FLCs who employ a third of California farmworkers often move crews of workers in buses and vans from farm to farm or have the workers transport themselves from farm to farm (Martin 2018). A worker may have only one FLC employer during the year but nonetheless work on many farms.

Table 2 shows that $55 \%$ of farmworkers had only one farm job in 2016, followed by a quarter with two farm jobs and a fifth with three or more farm jobs. There was a jump in the number of workers with three or more farm jobs between 2014 and 2016, from 13\% to 19\%, almost mirroring the fall in the number of one-employer workers from $60 \%$ to $55 \%$.

One explanation for more three-job workers is rising worker bargaining power. Fewer new foreign workers without authorization means that some employers who in the past refused to rehire workers who in a previous year had quit mid-season to pursue higher wages elsewhere now rehire such workers.

Table 3 shows the share of workers who had only one California farm job in 2016 by commodity. The highest percentage of one-job workers was on sheep and hog farms, where $92 \%$ of workers had only one job in 2016. In most animal agriculture, mushroom production and nursery crop production, about threefourths of workers had only one farm job.

The lowest percentage of one-job workers was in other berries (not strawberries), where $53 \%$ had only one farm job in 2016 . Between $60 \%$ and $65 \%$ of workers whose maximum earnings were in citrus, strawberries and grapes had only one farm employer, while $70 \%$ of those employed by FLCs had only one farm employer in 2016 .

\section{Unemployment insurance}

Agriculture is a seasonal industry and laid-off workers who are residing legally in the United States may apply for UI benefits. In 2016, some 185,410 laid-off farmworkers in California received $\$ 446$ million in UI benefits, an average of $\$ 2,405$ each (table 4 ). Almost 
three-fourths obtained two or three quarters of UI benefits, and about $84 \%$ of recipients collected $\$ 500$ to $\$ 5,000$. Half of those receiving UI benefits had only one farm job in 2016.

Table 5 shows that almost half of those whose maximum earnings were in logging and cotton ginning

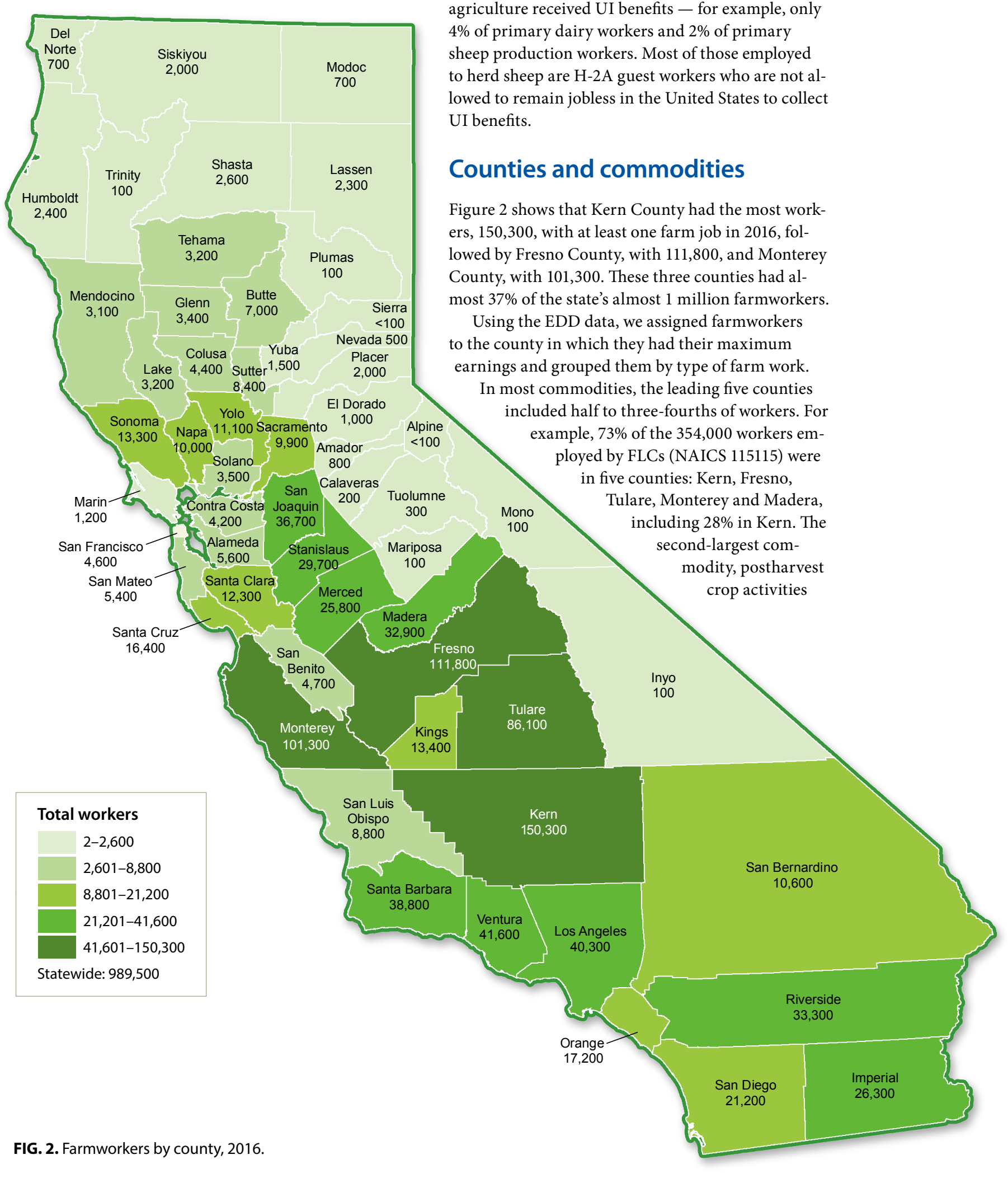

received UI benefits, although these sectors employed relatively few workers.

The largest sector with at least a quarter of primary workers obtaining UI benefits was grape vineyards, where $24 \%$ of the 44,000 workers received UI benefits, more than the average $19 \%$ of all primary workers who received UI benefits. Few primary workers in animal agriculture received UI benefits - for example, only $4 \%$ of primary dairy workers and $2 \%$ of primary sheep production workers. Most of those employed to herd sheep are $\mathrm{H}-2 \mathrm{~A}$ guest workers who are not alowed to remain jobless in the United States to collect

\section{Counties and commodities}

Figure 2 shows that Kern County had the most work2016, fol Using the EDD data, we assigned farmworkers the county in which they had their maximum luded half to three-fourths of workers. For ample, $73 \%$ of the 354,000 workers emed by FLCs (NAICS 115115) wer counties: Kern, Fresno ond-largest comdity, postharvest crop activities 
TABLE 6. Leading sectors for farmworkers, 2016

\begin{tabular}{|c|c|}
\hline County & $\begin{array}{c}\text { Number of } \\
\text { farmworkers }\end{array}$ \\
\hline \multicolumn{2}{|l|}{ Kern County } \\
\hline Farm labor contractors and crew leaders (FLC) & 97,900 \\
\hline Tree nut farming & 11,800 \\
\hline Grape vineyards & 11,300 \\
\hline Other vegetable and melon farming & 3,100 \\
\hline Other noncitrus fruit farming & 3,000 \\
\hline Total* & 150,300 \\
\hline \multicolumn{2}{|l|}{ Fresno County } \\
\hline Farm labor contractors and crew leaders (FLC) & 56,400 \\
\hline Postharvest crop activities & 13,700 \\
\hline Grape vineyards & 10,100 \\
\hline Other noncitrus fruit farming & 4,200 \\
\hline Tree nut farming & 3,900 \\
\hline Total* & 111,800 \\
\hline \multicolumn{2}{|l|}{ Monterey County } \\
\hline Farm labor contractors and crew leaders (FLC) & 40,700 \\
\hline Postharvest crop activities & 16,300 \\
\hline Strawberry farming & 13,200 \\
\hline Other vegetable and melon farming & 11,000 \\
\hline Crop harvesting, primarily by machine & 5,200 \\
\hline Total* & 101,300 \\
\hline \multicolumn{2}{|l|}{ Tulare County } \\
\hline Farm labor contractors and crew leaders (FLC) & 49,400 \\
\hline Postharvest crop activities & 6,700 \\
\hline Dairy cattle and milk production & 5,000 \\
\hline Grape vineyards & 3,700 \\
\hline Farm management services & 2,600 \\
\hline Total* & 86,100 \\
\hline \multicolumn{2}{|l|}{ Ventura County } \\
\hline Strawberry farming & 12,000 \\
\hline Farm labor contractors and crew leaders (FLC) & 9,700 \\
\hline Berry (except strawberry) farming & 5,400 \\
\hline Other vegetable and melon farming & 2,400 \\
\hline Employment services & 2,000 \\
\hline Total* & 41,600 \\
\hline
\end{tabular}

\section{FLCs employ a third of primary farmworkers, and their employees have the lowest FTE and average actual earnings.}

(NAICS 115114), included 70,000 workers, $71 \%$ of whom were in five counties: Monterey, Fresno, Imperial, Tulare and San Joaquin.

Table 6 shows the leading sectors of farm employment by county. For example, 97,900 of the 150,300 farmworkers in Kern County were reported by FLCs, followed by 11,800 workers in tree nut farming and 11,300 in grape vineyards; these three categories accounted for over $80 \%$ of the farmworkers employed in Kern County. In Fresno County, 56,400 workers were reported by FLCs, 13,700 in postharvest crop activities and 10,100 in grape vineyards; these three categories accounted for $72 \%$ of the workers reported in Fresno County.

In Monterey County, FLCs employed over $40 \%$ of primary farmworkers, followed by postharvest crop activities with $16 \%$ and strawberries with $13 \%$. Over $57 \%$ of Tulare County workers were employed by FLCs, followed by $8 \%$ in postharvest crop activities and $6 \%$ in dairies. In Ventura County, almost $30 \%$ of primary workers were employed in strawberry farming, followed by $23 \%$ employed by FLCs and $13 \%$ in other berries.

The number of farmworkers rose from 847,600 in 2015 to 989,500 in 2016, up 17\%. In Kern County, the number of farmworkers rose $25 \%$, in Fresno County by the statewide average of $17 \%$ and in Monterey County by $7 \%$.

California has a complex farm labor market that involves almost a million workers filling an average 425,000 FTE jobs; the total number of farm jobs is much larger than 425,000, since many farm jobs last only a few days or weeks. The number of farmworkers rose faster than average employment between 2015 and 2016, so that there were 2.3 workers per FTE job in 2016, up from 2.0 workers in 2015.

The fastest growing sector of agricultural employment, FLCs, is also the sector that offers the lowest average earnings. If the expansion of FLC employment continues, the ratio of workers to jobs could continue to increase, moving the farm labor market away from what public policy has long tried to achieve, a farm labor market with fewer workers who are employed most of the year.

\section{P. Martin is Professor Emeritus, Agricultural and Resource Economics, UC Davis; B. Hooker and M. Stockton are Research Specialists, Employment Development Department, state of California. \\ We acknowledge the support of the Giannini Foundation. \\ The views expressed in this report do not necessarily reflect the policies of the Employment Development Department of the state of California.}

\section{References}

Gifford Center [UC Davis Gifford Center for Population Studies]. 2018. April 12, 2018: NAWS 2018. https://gifford.ucdavis.edu/events/april-12-2018-naws-2018/\#us-andcalifornia-data

Martin P. 2018. Immigration and farm labor. In: Martin PL, Goodhue RE, Wright BD (eds.). California Agriculture: Dimensions and Issues. UC Giannini Foundation of Ag Econ. https://giannini.ucop.edu/publications/cal-ag-book/

Martin P, Hooker B, Stockton M. 2018. Employment and earnings of California farmworkers in 2015. Calif Agr 72(2):107-13. http://calag.ucanr.edu/ archive/?article=ca.2017a0043 


\title{
Cover crops prove effective at increasing soil nitrogen for organic potato production
}

\author{
Organic crops command high wholesale prices, but organic management of nutrient deficiencies \\ and pests can be a challenge.
}

by Rob Wilson, Darrin Culp, Skyler Peterson, Kevin Nicholson and Daniel Geisseler

\begin{abstract}
nterest in using organic cover crops and soil amendments is rapidly increasing in California as organic acreage expands. In the northeast corner of the state, several Klamath Basin producers are experimenting with transferring substantial acreage to organic production. Crops commonly grown in rotation in the area include small grains, fresh-market potatoes and alfalfa. In 2016, over 4,200 acres of potatoes and 13,100 acres of wheat were produced organically in California (USDA 2017).

Prices for wholesale organic crops are regularly higher than prices for conventional crops (Klonsky and Greene 2005). In the case of fresh-market potatoes, organic prices can exceed $185 \%$ of conventional prices (USDA 2017). On the other hand, organic management of nutrient deficiencies and pest problems is challenging. Nitrogen is a limiting nutrient in many California soils, especially when potatoes and grass crops are grown in multi-year rotations (Lynch et al. 2012). Most potato varieties require at least 200 pounds of nitrogen per acre, from all sources, to maximize yield and quality (Lazicki et al. 2016). Potatoes also require a steady
\end{abstract}

\section{Abstract}

Many farms in northeast California are experimenting with organic production to take advantage of price premiums and niche markets. A common challenge in organic farming is finding dependable nitrogen sources to meet the needs of vegetable and grass crops, especially in fields with low soil nitrogen. This study assessed the use of cover crops and organic amendments for increasing soil nitrogen for potato production at the Intermountain Research and Extension Center in Tulelake. Researchers evaluated several cover crop species, three planting dates and multiple cover crop mixes. Amendments included composts, manures, bloodmeal and soymeal. The data collected in the study included total nitrogen from cover crops and amendments, plant-available nitrogen in the soil, potato petiole nitrate and crop yield and quality. Vetches and field peas, managed as green manure, were successful at satisfying potatoes' in-season nitrogen demand. These cover crops, grown alone or in mixes with non-legume species, produced potato crops whose yield and quality were similar to crops grown with conventional fertilizers. The cover crops' influence on potato pest pressure was neutral. Chicken manure was the most cost-effective amendment for satisfying potatoes' in-season nitrogen demand.

Fall cover crops shortly

before harvest and incorporation. According to UCCE researchers. vetches and field peas helped produce potato crops whose yield and quality were similar to crops grown with conventional fertilizers. 
Planting a spring cover crop trial at IREC. As part of the research project, cover crop species such as grasses, vetches, field peas and mustards, as well as mixes of these species, were planted in spring, mid-summer and fall. Potatoes were planted the year after cover crops were grown. source of nitrogen throughout the growing season to prevent yield reductions and physiological disorders (Stark et al. 2004).

Common organic farming practices for increasing soil nitrogen include using certified amendments, such as manures, or growing cover crops (Finckh et al. 2006). Manure, compost and organic fertilizers derived from animal and plant matter contain several plant nutrients, including nitrogen (Möller 2018). Manures are especially beneficial to soils deficient in phosphorus or potassium because the percentages of phosphorus and potassium found in most manure types are similar to or greater than the percentage of nitrogen found in the same manure type (Duru 1987). Cover crops have long been identified as beneficial to soil health because of their ability to increase soil carbon, decrease soil erosion and increase water infiltration (Kaspar and Singer 2011). Cover crops also influence soil nutrient recycling and nutrient availability. This is especially true of legumes - which, through a symbiotic relationship with bacteria, fix atmospheric nitrogen (Fageria et al. 2005). When legume leaves and stems decompose, plant-available nitrogen is added to the soil (Sincik et al. 2008).

A challenging aspect of using amendments and cover crops to fertilize potatoes is accurately predicting when the nitrogen in these products will become available to the crop (Sullivan and Andrews 2012). Adequate nitrogen must be available at potato planting to support vegetative vine growth and tuber set, while nitrogen availability in mid-summer is critical for tuber bulking (Alva 2004). Nutrient mineralization is driven by the decomposition of organic compounds into soluble inorganic forms that are available to plants (Whalen 2014). Since cover crops and manures are composed of organic material, farmers rely on the mineralization process to draw from these products plant-available

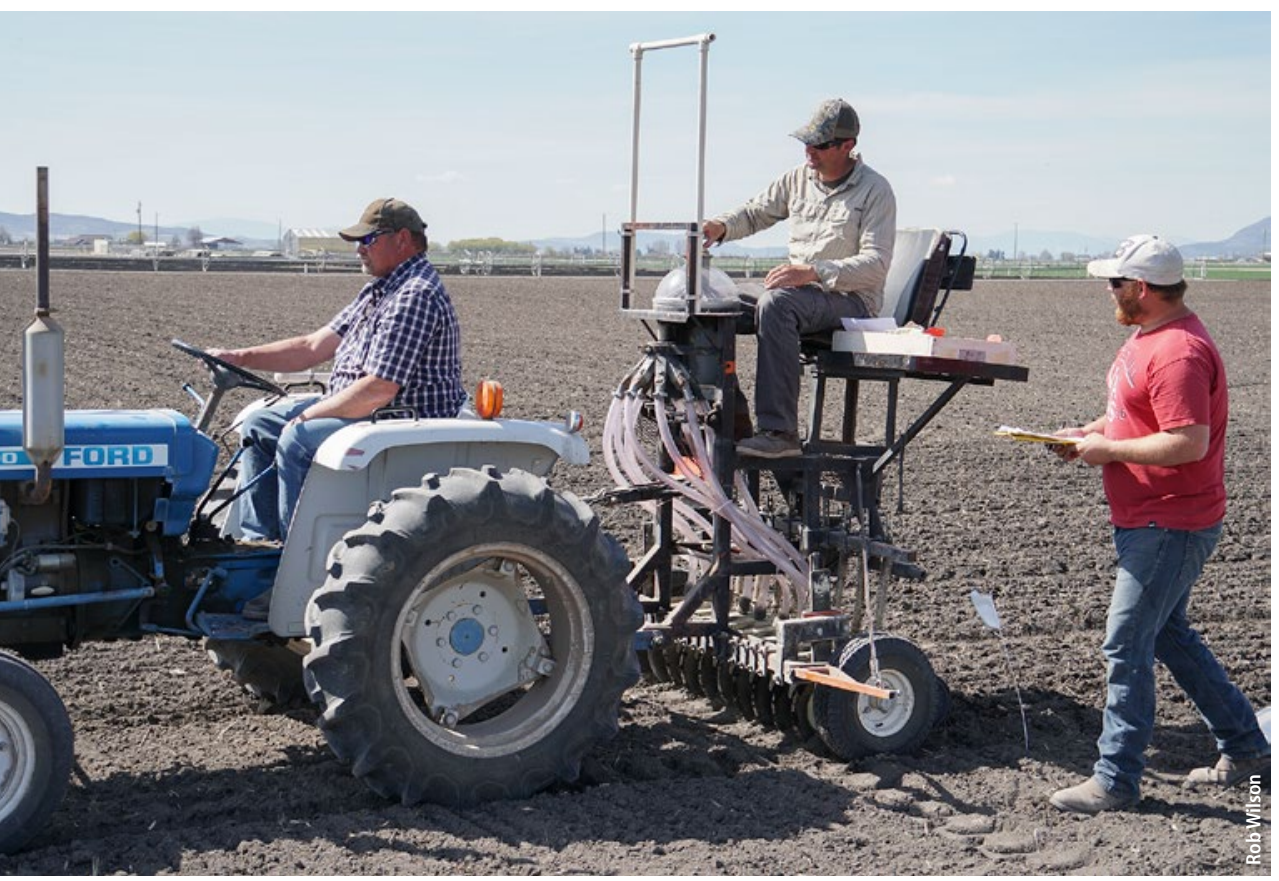

nitrogen that can feed their crops. Many factors influence a material's mineralization, including the carbonto-nitrogen ratio of the material, soil temperature, soil moisture and soil type. Accurate mineralization estimates require field testing under local conditions (Hartz et al. 2000).

Cover crops can have a positive or negative influence on potato pests such as weeds, nematodes, diseases and insects (Wyland et al. 1996; Larkin et al. 2010). Several plant species in the Brassica genus have been shown to produce high levels of glucosinolates, which can facilitate biofumigation when incorporated into the soil (Gimsing and Kirkegaard 2009). Oilseed radish has been shown to serve as a trap crop for cyst nematode (Hemayati et al. 2017). Some cover crops can promote potato diseases and nematodes by serving as a host and green bridge (Sharma-Poudyal et al. 2016). ("Green bridge" is the term applied to green plant material from volunteer plants, weeds and cover crops in which pathogen inoculums and pest populations increase between harvest of one crop and emergence of a newly planted crop.)

Barriers to widespread use of cover crops and other organic amendments in potatoes include costs related to materials, labor, transportation and application. Cover crops require time and resources to manage and do not provide the benefit of crop revenue. In urban areas, strong odors from manures are a disincentive (Larney and Blackshaw 2003). Cover crops and amendments with a high carbon-to-nitrogen ratio, such as grasses and brown composts, can often lead to a temporary immobilization of plant-available nitrogen (Sullivan and Andrews 2012), which is the opposite of the effect that potato growers are pursuing. In northeast California, nitrogen immobilization and the opportunity cost of cover cropping can be particularly problematic because growers have a small window of frost-free days in which to grow crops.

\section{Structure of research}

For this research project, multiple studies were conducted from 2014 to 2017 at the UC ANR Intermountain Research and Extension Center (IREC) in Tulelake, Siskiyou County, to evaluate the influence of cover crops, amendments and combinations of the two in a potato crop grown without synthetic fertilizers and pesticides. All cover crop and amendment trials were conducted alongside control treatments that included an unamended control as well as urea applications of 75 and 150 pounds of nitrogen per acre. All treatments were replicated four times. The primary study objective was to quantify the effect of cover crops and amendments on soil fertility, potato yield and potato pests.

\section{Cover crops}

Two cover crop studies were conducted at IREC - a study begun in 2014 that evaluated mid-summer cover crops and a study begun in 2016 that evaluated cover 
crops planted in spring, mid-summer and fall. Cover crop planting times and species were selected to fit local cropping systems and to maximize biomass production under local growing conditions. For example, planting cover crops in mid-summer is desirable for producers growing a grain hay crop because the mid-summer planting occurs shortly after hay harvest, which allows producers to generate crop income. A mid-summer planting also allows cover crop growth during the warm temperatures of summer and early fall. Planting cover crops in the spring is a good fit for producers with limited water availability because it takes advantage of stored winter soil moisture and cool, wet weather conditions during establishment. Planting in the fall is a good fit for producers who want to grow a full-season cash crop, such as hard red wheat, because fall planting allows them to plant after cash crop harvest. Fall planting is also desirable because the cover crop can prevent soil erosion during winter and early spring.

In both studies, potatoes were planted the year after cover crops were grown. Cover crop species included cool-season and warm-season species, seeded alone and in mixes. Cover crop species were selected based on their previous success in the local area or on previous research documenting success under similar growing conditions. A list of species evaluated is shown in table 1 . Cover crops were drill-seeded into a disked, packed seedbed using a drill cone planter with drill rows spaced 6 inches apart. Cover crop plant density was estimated using visual plant counts within a central rectangle in each plot, measuring 5 feet by 10 feet, when plants were 3 to 5 inches tall. Cover crops were grown under sprinkler irrigation, without synthetic fertilizer or pesticides. They were managed as a green manure by flail-mowing and disk-incorporating aboveground biomass at early flowering. Cover crop biomass in each plot was estimated from a quadrat of 5 feet by 10 feet. An aboveground biomass subsample was sent to a laboratory to estimate total nitrogen content in cover crop biomass. An untreated fallow treatment and a urea treatment were included in all trials for comparison purposes. The fallow treatment for spring cover crops was fallowed for 12 months before potato planting; the fallow treatment for mid-summer cover crops was fallowed, after harvest of the barley hay crop, for 8.5 months before potato planting; and the fallow treatment for fall cover crops and several amendments was fallowed, after harvest of the barley grain crop, for 6.5 months before potato planting. All fallow treatments, after weed suppression ratings were taken, were hand-weeded to prevent excessive weed growth and weed seed production.

Planting of the spring cover crop occurred in midApril. Mid-summer plantings occurred in late July, after a spring barley hay crop was grown. The fall cover crop planting occurred in mid-September, also after a spring barley grain crop was grown. Cover crops were incorporated into the soil at $50 \%$ flowering -71 to 77 days after planting for the spring planting, 70 to 76 days
TABLE 1. Cover crop seeding rate and inclusion in spring, summer and fall cover crop plantings

\begin{tabular}{|l|l|l|l|}
\hline Cover crop & $\begin{array}{c}\text { Seeding } \\
\text { rate }\end{array}$ & $\begin{array}{l}\text { Common planting } \\
\text { times }\end{array}$ & $\begin{array}{l}\text { Planting time in } \\
\text { trials }\end{array}$ \\
\hline Grasses & & & \\
\hline SX 17 sorghum sudangrass & $30 \mathrm{lb} / \mathrm{acre}$ & Summer & Summer \\
\hline Trical 141 spring triticale & $90 \mathrm{lb} /$ acre & Spring & Summer \\
\hline Trical 102 winter triticale & $90 \mathrm{lb} / \mathrm{acre}$ & Fall & Summer, fall \\
\hline Twin spring wheat & $70 \mathrm{lb} / \mathrm{acre}$ & Spring & Spring \\
\hline
\end{tabular}

Legumes

\begin{tabular}{lcll} 
AC Greenfix chickling vetch & $60 \mathrm{lb} / \mathrm{acre}$ & Spring, summer, fall & Summer \\
\hline Banner spring field pea & $172 \mathrm{lb} /$ acre & Spring, summer, fall & Summer \\
\hline Berseem clover & $20 \mathrm{lb} /$ acre & Summer & Summer \\
\hline Cowpea & $40 \mathrm{lb} / \mathrm{acre}$ & Summer & Summer \\
\hline Flex spring field pea & $120 \mathrm{lb} / \mathrm{acre}$ & Spring, summer, fall & Spring, summer, fall \\
\hline Hairy vetch & $50 \mathrm{lb} / \mathrm{acre}$ & Spring, fall & Summer \\
\hline Journey spring field pea & $147 \mathrm{lb} / \mathrm{acre}$ & Spring, summer, fall & Summer \\
\hline Koyote winter field pea & $154 \mathrm{lb} /$ acre & Fall & Summer \\
\hline Lana woollypod vetch & $60 \mathrm{lb} /$ acre & Spring, fall & Spring, summer, fall \\
\hline Nutrigreen winter field pea & $139 \mathrm{lb} /$ acre & Fall & Fall
\end{tabular}

\section{Mustards}

\begin{tabular}{|l|l|l|l|}
\hline Caliente 199 mustard & $10 \mathrm{lb} /$ acre & Spring & Spring, summer \\
\hline Nemat arugula & $6 \mathrm{lb} / \mathrm{acre}$ & Spring, fall & Spring, fall
\end{tabular}

Radish

Defender oilseed radish

\section{$50 / 50$ mixes}

Arugula and spring field pea

Flex spring field pea

Nemat arugula

Mustard and spring field pea

Caliente 199 mustard

Flex spring field pea

Mustard and woollypod vetch

Caliente 199 mustard

Lana woollypod vetch

Radish and spring field pea

Defender oilseed radish

Flex spring field pea

Triticale and vetch

Lana woollypod vetch

Trical 102 winter triticale
$15 \mathrm{lb} /$ acre Spring, fall

Spring, summer
Spring

$3 \mathrm{lb} / \mathrm{acre}$

$$
\text { Spring, fall }
$$

Spring

$5 \mathrm{lb} / \mathrm{acre}$

$60 \mathrm{lb} / \mathrm{acre}$

Spring, summer, fall

Summer

$5 \mathrm{lb} / \mathrm{acre}$

$30 \mathrm{lb} / \mathrm{acre}$

$7.5 \mathrm{lb} / \mathrm{acre}$

Spring, summer, fall

Summer

$60 \mathrm{lb} / \mathrm{acre}$

Fall

Fall
$60 \mathrm{lb} / \mathrm{acre}$
$30 \mathrm{lb} / \mathrm{acre}$

$45 \mathrm{lb} / \mathrm{acre}$ 
Grading potatoes at IREC. Potatoes were graded by counting all potatoes in each plot and mechanically sorting them by weight into five size classes based on U.S. grade and carton classes. after planting for mid-summer plantings and 230 days after planting for the fall planting. Fall-planted cover crops did not reach the flowering stage before incorporation. The reason for early termination of fall-planted cover crops was to allow 4 weeks between cover crop incorporation and potato planting and thus enable cover crop decomposition and prevent a green bridge. Total applied water for irrigated cover crop trials was 12 inches for the spring planting, 6 to 8 inches for midsummer plantings and 3.5 inches for the fall planting. Cover crop vigor was determined by visually evaluating plant canopy cover and height in the plot area, with a vigor score of 10 equal to the most vigorous growth and 1 equal to bare ground. Weed suppression ratings were determined by visually evaluating the density and height of weeds in each plot. A weed suppression rating equal to 10 represented zero weeds in the plot and 1 was equal to weed density and height similar to the unplanted bare-ground control. Weed suppression ratings were taken when weeds and cover crops were 6 to 10 inches tall. Weed biomass was measured in each plot at the time of cover crop harvest by hand-separating cover crop and weed plant material derived from the quadrat sample.

\section{Organic amendments}

Two amendment studies were conducted at IREC. One study evaluated fall-applied amendments in 2014 and another study evaluated amendments applied in fall 2016 and spring 2017. Amendments were applied by hand and disk-incorporated into the soil - in midSeptember for fall applications and in late April for spring applications. The tested organic amendments included chicken manure, steer manure, composted

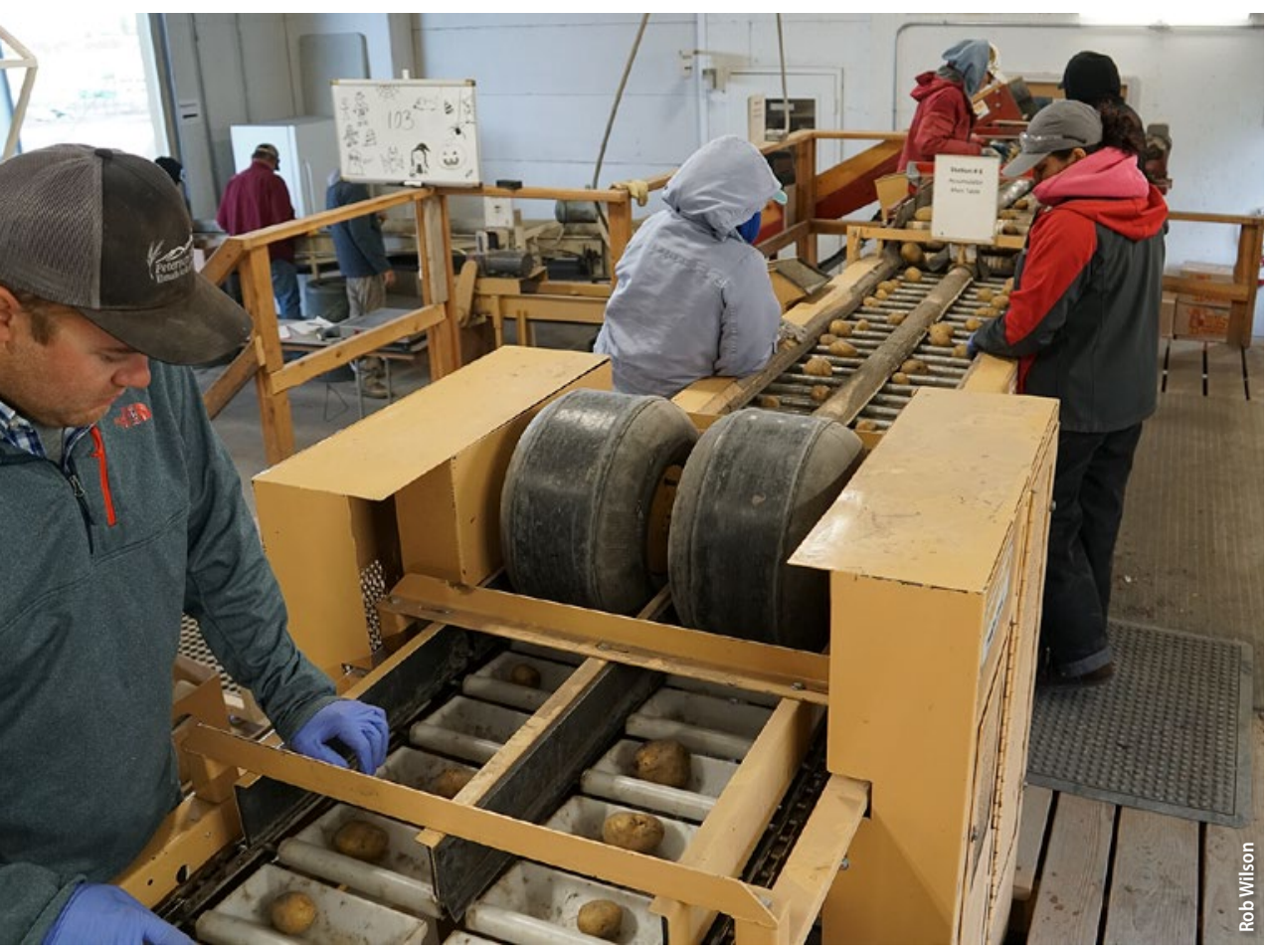

chicken manure and a compost mix using green waste and cow manure. Bloodmeal and soymeal were broadcast-applied and incorporated using a Lilliston cultivator after bed preparation and before planting. These two amendments were included to represent organic alternatives to quick-release synthetic nitrogen fertilizers such as urea. Amendment application rates were based on the products' moisture and nitrogen content, with the goal of applying 150 pounds of nitrogen per acre (assuming 100\% dry matter). Amendment application rates ranged from 1,100 pounds per acre for bloodmeal with $13 \%$ nitrogen to 10,000 pounds per acre for compost with $1.5 \%$ nitrogen. The nitrogen mineralization rates for the amendments varied and were not controlled in the experiment.

\section{Potato production}

Potatoes were planted over areas treated with cover crops, amendments and combinations of cover crops and amendments. Potatoes were also planted over areas treated with urea fertilizer and over untreated fallow areas. Planting occurred in the spring, without the use of synthetic fertilizers or pesticides. Preplant soil samples were taken at potato planting to confirm that supplies of phosphorus, potassium, sulfur and calcium were adequate to avoid deficiencies; all soil tests showed adequate nutrient levels according to University of California guidelines (CDFA 2015; Lang at al. 1999). Potato row spacing was 36 inches and seed spacing was 10 inches. The Russet Norkotah potato variety was evaluated in 2015 and the Yukon Gold variety was evaluated in 2017. Soil samples were collected from each plot shortly before planting to determine nitrate available at preplanting, as well as available ammonium and total nitrogen. Plot size was 12 feet by 40 feet; all sampling occurred in a middle area, measuring 6 feet by 30 feet, to avoid edge effects. The soil type at IREC is a Tulebasin mucky silty clay loam with $4.5 \%$ organic matter. To meet crop evapotranspiration needs, potatoes were irrigated with solid-set irrigation that entailed use of soil moisture monitors and an on-site CIMIS weather station.

Crop vigor was monitored multiple times during the growing season by visually evaluating plant canopy cover, height and color over the plot area, with a vigor score of 10 equal to plants in the plot with the highest canopy cover and a dark-green color and 0 equal to short, senesced, yellow plants. Petiole nitrogen was measured at early tuber bulking and at crop maturity. Potatoes from each plot were mechanically harvested and graded to determine fresh-market tuber yield and tuber quality. Potatoes were graded by counting all potatoes in each plot and mechanically sorting them by weight into five size classes based on U.S. grade and carton classes. Tuber quality was determined by counting and weighing all cull tubers that displayed rot, greening, knobs, growth cracks, irregular shape and irregular skin appearance. A 10-tuber subsample from each plot was evaluated for internal defects including 
hollow heart, brown spot bruise, vascular discoloration and specific gravity.

\section{Postharvest monitoring}

Available soil nitrogen (ammonium and nitrate) was measured after potato harvest to quantify remaining nitrogen at soil depths of $0-10$ inches and 10-20 inches. Winter wheat, a common rotation crop with potatoes, was planted in October after potato harvest. The flagleaf nitrogen content and the grain yield of winter wheat were measured for select treatments to estimate the enduring effects of treatments.

\section{Establishment, vigor and weed suppression}

Cover crop establishment in all trials was successful. Plant densities were measured at or above $80 \%$ of the seeding rate (data not shown), with two exceptions - a crop of cowpeas seeded in mid-summer (plant density of $73 \%$ ) and a crop of spring-seeded arugula (plant density of 50\%). Low plant density for spring arugula was probably due to planting too deep. Arugula requires a shallow seeding depth of less than 0.5 inch. Subsequent seedings of arugula at the correct seeding depth produced plant density higher than $80 \%$. Spring wheat, fall triticale, woollypod vetch, field peas, spring mustard and oilseed radish displayed rapid growth, high vigor and high weed suppression (table 2). Mixes of mustards and field peas or vetch, in 50/50 proportions, also had high vigor and high weed suppression. Spring-seeded arugula exhibited lower vigor and weed suppression than the other spring cover crops, likely due to the stand problems associated with excessively deep seeding.

Oilseed radish, mustards and grasses planted in mid-summer, after a spring barley crop, exhibited lower vigor and biomass than spring plantings (table 2). This effect was caused by a deficiency of plant-available nitrogen at planting; the mustards, radish and grasses had low nitrate in plant tissue during the early season (data not shown) and a low percentage of nitrogen biomass at harvest compared to spring plantings (table 3 ). Nitrate nitrogen in the top 10 inches of fallow plots averaged 17 parts per million (ppm) at the spring planting and below $5 \mathrm{ppm}$ at the mid-summer and fall plantings. These nitrate concentrations respectively correspond to approximately 28 and 8 pounds of nitrogen per acre in the top 10 inches of the profile. Many growers express interest in growing a spring barley or wheat crop for revenue before planting cover crops, but these results clearly show that adequate mineralized soil nitrogen is needed for non-legume cover crops to flourish. The idea that legumes might contribute nitrogen to non-legume cover crops in a mixed planting was not supported, as mustard, radish and grass grown in a mix with field peas and vetches had vigor and biomass similar to the single-species planting; the mix was instead dominated by field peas, which fixed their own nitrogen but did not share it with other species.
Cowpeas, berseem clover and sorghum-sudangrass planted in mid-summer died at the first killing frost in early September and failed to produce significant biomass (table 2). Field peas, woollypod vetch, mustard, oilseed radish and 50/50 mixes had high weed

TABLE 2. Cover crop vigor, weed suppression and biomass yield

\begin{tabular}{|c|c|c|c|}
\hline \multirow[b]{2}{*}{ Cover crop } & Vigor & $\begin{array}{c}\text { Weed } \\
\text { suppression }\end{array}$ & \multirow{2}{*}{$\begin{array}{c}\text { Biomass yield at } \\
\text { incorporation } \\
100 \% \text { dry tons/ } \\
\text { acre }\end{array}$} \\
\hline & \multicolumn{2}{|c|}{$1-10$ scale $; 10=$ best $^{*}$} & \\
\hline \multicolumn{4}{|l|}{ Grasses } \\
\hline $\begin{array}{l}\text { SX } 17 \text { sorghum-sudangrass } \\
\text { (summer) } \dagger\end{array}$ & 7 & 5 & 0.8 \\
\hline Trical 102 winter triticale (fall) & 7 & 9 & 1 \\
\hline Trical 141 spring triticale (summer) & 6 & 5 & 0.4 \\
\hline Twin spring wheat (spring) & 8 & 8 & 3 \\
\hline
\end{tabular}

\section{Legumes}

\begin{tabular}{|llll}
\hline $\begin{array}{l}\text { AC Greenfix chickling vetch } \\
\text { (summer) }\end{array}$ & 7 & 8 & 2 \\
\hline Banner spring field pea (summer) & 8 & 8 & 2.8 \\
\hline Berseem clover (summer) & 4 & 5 & 1.4 \\
\hline Cowpea (summer) & 5 & 3 & 0.1 \\
\hline Flex spring field pea (spring) & 8 & 8 & 2.7 \\
\hline Hairy vetch (summer) & 8 & 8 & 2.2 \\
\hline Journey spring field pea (summer) & 8 & 8 & 2.5 \\
\hline Koyote winter field pea (summer) & 7 & 6 & 2.2 \\
\hline Lana woollypod vetch (fall) & 8 & 9 & 2.1 \\
\hline Lana woollypod vetch (spring) & 8 & 7 & 2.1 \\
\hline Lana woollypod vetch (summer) & 8 & 8 & 2.4 \\
\hline Nutrigreen winter field pea (fall) & 7 & 7 & 1.6 \\
\hline
\end{tabular}

\begin{tabular}{|c|c|c|c|}
\hline \multicolumn{4}{|l|}{ Mustards } \\
\hline Caliente 199 mustard (spring) & 7 & 8 & 2.3 \\
\hline Caliente 199 mustard (summer) & 6 & 9 & 0.8 \\
\hline Nemat arugula (spring) & 6 & 5 & 1.7 \\
\hline
\end{tabular}

Radish

\begin{tabular}{llll} 
Defender oilseed radish (spring) & 8 & 8 & 2.7 \\
\hline Defender oilseed radish (summer) & 5 & 9 & 0.4
\end{tabular}

\section{$50 / 50$ mixes}

Arugula and spring field pea (spring)

Mustard and spring field pea (spring)

Mustard and woollypod vetch

(summer)

Radish and spring field pea (summer)

Triticale and woollypod vetch (fall)

\begin{tabular}{|l|l|l|}
\hline 7 & 6 & 1.8 \\
\hline 8 & 8 & 2.2 \\
\hline 8 & 9 & 2.3 \\
\hline 8 & 9 & 1.7 \\
\hline 9 & 10 & 2.3 \\
\hline
\end{tabular}

* Cover crop vigor scale: $10=$ the most vigorous growth in study area and $1=$ bare ground. Weed suppression scale: $10=$ zer weeds and $1=$ weed density and height similar to those in the unplanted bare-ground control. Weed suppression ratings were determined by visually evaluating weed density and height in each plot.

† Information in parentheses represents planting time for presented data. 
suppression ratings in the mid-summer trial (table 2). Spring field pea varieties exhibited greater vigor and biomass than winter field pea varieties in mid-summer plantings (table 2).

\section{Cover crops' influence on nitrogen}

Field pea and vetch green manures contributed substantial nitrogen to the system, adding over 150 pounds - and in many cases over 200 pounds - of nitrogen per acre from aboveground biomass (table 3 ). The highest nitrogen contributor was spring-planted "flex" field peas, which added 306 pounds of nitrogen per acre. Berseem clover and cowpeas contributed less than 70 pounds of nitrogen per acre because Tulelake's short growing season was too cold for these species to reach maturity before frost. Several grass and mustard cover crops produced significant biomass, but their nitrogen content was less than half of that produced by most legume species (table 3). More than 150 pounds of nitrogen per acre were contributed by $50 / 50$ mixes of legumes and either grass or mustard.

Mineralized nitrogen (soil nitrate and ammonium) at the time of potato planting was correlated $(r=0.72)$ to added nitrogen from cover crops (table 3 ), suggesting that little nitrogen was lost to leaching or denitrification over the winter. Mineralized nitrogen in the top 10 inches of soil for most field peas and vetches was more than double that for non-legume cover crops. Aboveground biomass (leaves and stems) contained most of the nitrogen from legume green manure. Mineralized nitrogen at potato planting, in treatments that involved haying field peas' aboveground biomass

TABLE 3. Influence of added N from cover crops, amendments and controls on mineralized nitrogen at potato planting and early bulking

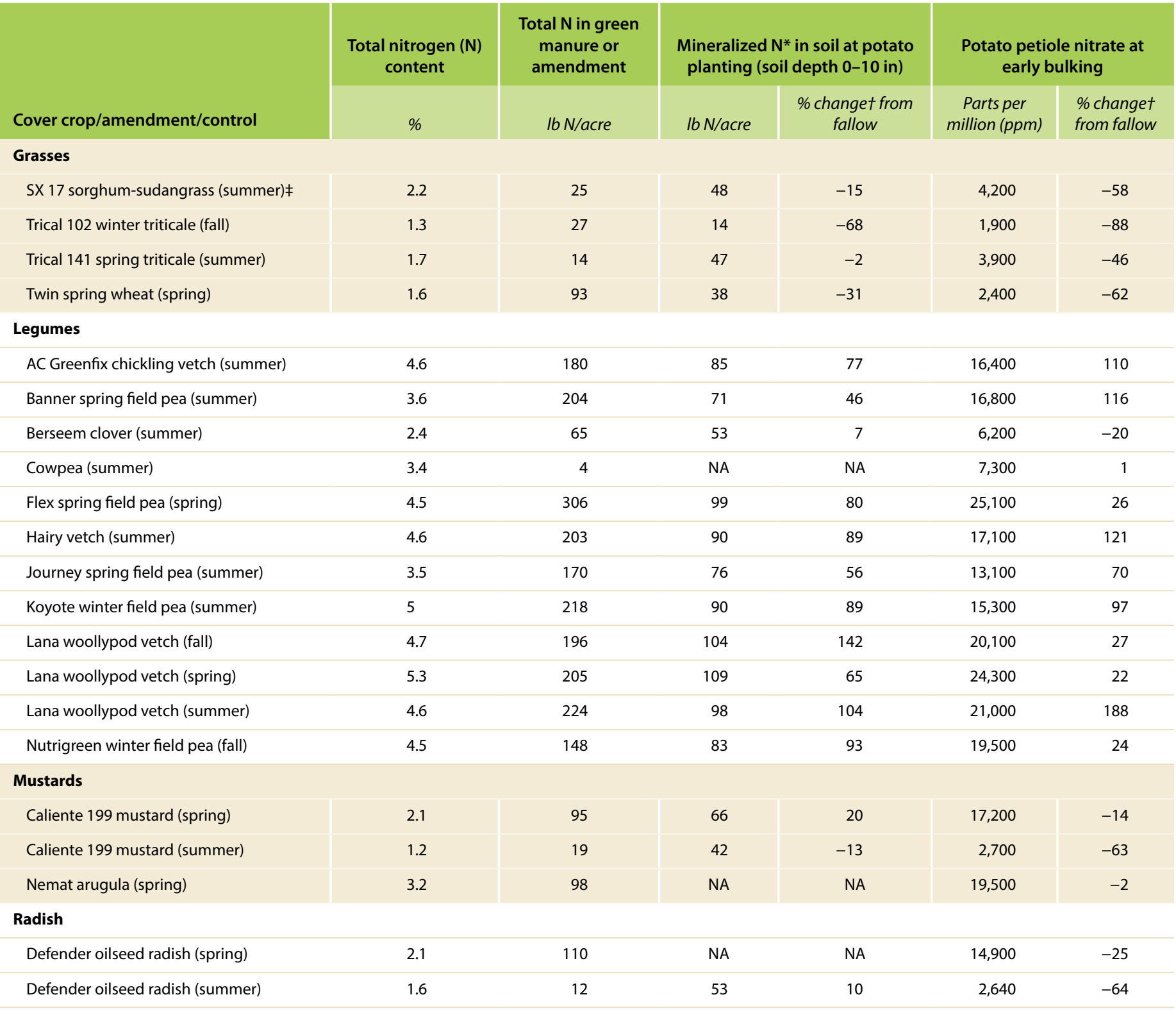


and removing it from the field (data not shown), was no different from fallow treatments. This is consistent with other studies (Kuo and Sainju 1997, 1998) demonstrating that aboveground biomass contains most of the nitrogen in legume cover crops. Mineralized nitrogen at potato planting in fallow treatments averaged 55 pounds of nitrogen per acre for spring fallow, 48 pounds per acre for mid-summer fallow and 43 pounds for fall fallow. Mustard, radish and sorghum-sudangrass resulted in mineralized nitrogen similar to that of fallow treatments, suggesting these cover crops had a neutral effect on soil nitrogen (table 3). Spring wheat and fall triticale resulted in lower mineralized nitrogen at potato planting than was measured in fallow treatments, likely because decomposition of grass residue tied up available nitrogen. Delayed release of nitrogen in potatoes is problematic because potatoes require adequate nitrogen in the early season for vegetative growth and tuber initiation.

Potato petiole nitrate at early bulking was used to evaluate in-season nitrogen availability. Legume cover crops resulted in much higher potato petiole nitrate at early bulking than did grasses; petiole nitrate for treatments with field peas and vetches was similar to petiole nitrate produced in conventional fertilizer controls (table 3). When comparing potato petiole nitrate in cover crop treatments to that in fallow treatments, legumes were higher, mustards were similar and grasses were lower (table 3).

One year after growing potatoes (and 2 years after cover crop production), flag leaf nitrogen in winter wheat was higher in plots that had received spring

TABLE 3. Influence of added $N$ from cover crops, amendments and controls on mineralized nitrogen at potato planting and early bulking

\begin{tabular}{|c|c|c|c|c|c|c|}
\hline \multirow[b]{2}{*}{ Cover crop/amendment/control } & \multirow{2}{*}{$\begin{array}{c}\text { Total nitrogen }(\mathrm{N}) \\
\text { content } \\
\\
\%\end{array}$} & \multirow{2}{*}{$\begin{array}{c}\text { Total } \mathrm{N} \text { in green } \\
\text { manure or } \\
\text { amendment }\end{array}$} & \multicolumn{2}{|c|}{$\begin{array}{l}\text { Mineralized } \mathrm{N}^{*} \text { in soil at potato } \\
\text { planting (soil depth } 0-10 \mathrm{in} \text { ) }\end{array}$} & \multicolumn{2}{|c|}{$\begin{array}{l}\text { Potato petiole nitrate at } \\
\text { early bulking }\end{array}$} \\
\hline & & & Ib N/acre & $\begin{array}{l}\% \text { changet from } \\
\text { fallow }\end{array}$ & $\begin{array}{c}\text { Parts per } \\
\text { million (ppm) }\end{array}$ & $\begin{array}{l}\% \text { changet } \\
\text { from fallow }\end{array}$ \\
\hline \multicolumn{7}{|l|}{$50 / 50$ mixes } \\
\hline Arugula and spring field pea (spring) & 5 & 178 & NA & NA & 21,700 & 9 \\
\hline Mustard and spring field pea (spring) & 4.2 & 187 & 82 & 49 & 20,900 & 5 \\
\hline Mustard and woollypod vetch (summer) & 3.3 & 150 & 69 & 44 & 14,100 & 93 \\
\hline Radish and spring field pea (summer) & 3.2 & 112 & 72 & 50 & 12,500 & 71 \\
\hline Triticale and woollypod vetch (fall) & 4.2 & 190 & 91 & 112 & 19,500 & 24 \\
\hline \multicolumn{7}{|l|}{ Manure and amendments } \\
\hline Composted chicken manure (spring) & 2.9 & 150 & 114 & 165 & 19,000 & 42 \\
\hline Composted chicken manure (fall) & 2.9 & 150 & 79 & 65 & 19,100 & 44 \\
\hline Dried steer manure (fall) & 0.9 & 150 & 51 & -7 & 9,680 & -15 \\
\hline Explorer $16-0-0$ soy protein (planting) & 16 & 150 & NA & NA & 20,500 & 44 \\
\hline Green waste/cow manure compost (fall) & 1.2 & 150 & 39 & -18 & 10,400 & -14 \\
\hline Perfect Organic Blend 4-4-4 pellets§ (fall) & 4.4 & 150 & 118 & 127 & 22,200 & 57 \\
\hline Pro-Pell-It! 13-0-0 bloodmeal (planting) & 13 & 150 & NA & NA & 22,600 & 46 \\
\hline Stutzman Nutri-Rich 4-3-2 pellets§ (fall) & 3.7 & 150 & 81 & 58 & 21,000 & 35 \\
\hline \multicolumn{7}{|l|}{ Controls $\uparrow$} \\
\hline Fallow (amendment trial) & NA & 0 & 51 & 0 & 11,800 & 0 \\
\hline Fallow (fall cover crop trial) & NA & 0 & 43 & 0 & 15,800 & 0 \\
\hline Fallow (spring cover crop trial) & NA & 0 & 55 & 0 & 19,900 & 0 \\
\hline Fallow (summer cover crop trials) & NA & 0 & 48 & 0 & 7,530 & 0 \\
\hline Urea fertilizer $-75 \mathrm{lb}$ N/acre (planting) & 46 & 75 & NA & NA & 17,200 & 25 \\
\hline Urea fertilizer - $150 \mathrm{lb}$ N/acre (planting) & 46 & 150 & NA & NA & 23,600 & 72 \\
\hline $\begin{array}{l}\text { * Mineralized } \mathrm{N} \text { included } \mathrm{NO}_{3-\mathrm{N}} \text { and } \mathrm{NH}_{4-\mathrm{N}} \text {. } \\
\text { † Percentage change from untreated fallow. The mean val } \\
\text { ‡ Information in parentheses represents cover crop planti } \\
\text { § Chicken manure is the primary ingredient in Stutzman } \mathrm{N} \\
\text { n Data for fallow and urea fertilizer treatments is reported }\end{array}$ & $\begin{array}{l}\text { cross studies is presented fo } \\
\text { ime or, for manures and ame } \\
\text {-Rich 4-3-2 and Perfect Orga } \\
\text { he mean value across years a }\end{array}$ & $\begin{array}{l}\text { atments replicated in mul } \\
\text { nents, time of incorporatic } \\
\text { Blend 4-4-4. }\end{array}$ & $\begin{array}{l}\text { le studies. } \\
\text { Treatments condu }\end{array}$ & at planting occurred aft & pring soil sampling. & \\
\hline
\end{tabular}


vetch and field pea treatments than in fertilizer controls and fallow treatments (data not shown). Plots that had been planted with field peas and vetches in mid-summer were associated with lower flag leaf nitrogen than plots that had received spring plantings of field peas

TABLE 4. Influence of 2014 summer-planted cover crops, 2014 fall-applied amendments and 2015 fertilizers applied at planting on 2015 Russet Norkotah potato yields

\begin{tabular}{|c|c|c|c|c|}
\hline & Total yield & US \# 1 yield & $\begin{array}{c}\text { Average } \\
\text { tuber } \\
\text { size }\end{array}$ & $\begin{array}{c}\text { Cull } \\
\text { yield* }\end{array}$ \\
\hline Cover crop & $\begin{array}{c}\text { Hundred } \\
\text { weight/acre }\end{array}$ & $\begin{array}{l}\text { Hundred } \\
\text { weight/acre }\end{array}$ & $O Z$ & $\% t$ \\
\hline \multicolumn{5}{|l|}{ Grasses } \\
\hline SX 17 sorghum-sudangrass & 311 & 247 & 6.1 & 3.5 \\
\hline Trical 102 triticale & 351 & 285 & 6.7 & 3 \\
\hline \multicolumn{5}{|l|}{ Legumes } \\
\hline AC Greenfix chickling vetch & 397 & 313 & 7.3 & 4.7 \\
\hline Banner spring field pea & 378 & 284 & 6.8 & 7.9 \\
\hline Berseem clover & 344 & 267 & 6.5 & 3.8 \\
\hline Flex spring field pea & 388 & 294 & 7 & 6.4 \\
\hline $\begin{array}{l}\text { Flex spring field pea (harvested } \\
\text { for hay) }\end{array}$ & 324 & 225 & 5.6 & 5.1 \\
\hline Hairy vetch & 414 & 307 & 7.5 & 10 \\
\hline Journey spring field pea & 385 & 298 & 6.8 & 5.9 \\
\hline Koyote winter field pea & 357 & 256 & 7 & 10.1 \\
\hline Lana woollypod vetch & 428 & 339 & 8 & 6.9 \\
\hline Nutrigreen winter field pea & 381 & 287 & 6.9 & 5.9 \\
\hline
\end{tabular}

Manure and amendments

\begin{tabular}{|c|c|c|c|c|}
\hline Dried steer manure (fall)‡ & 394 & 285 & 6.5 & 11.9 \\
\hline $\begin{array}{l}\text { Explorer } 16-0-0 \text { soy protein } \\
\text { fertilizer at planting }\end{array}$ & 424 & 286 & 7.1 & 17.1 \\
\hline $\begin{array}{l}\text { Green waste/cow manure } \\
\text { compost (fall) }\end{array}$ & 383 & 284 & 6.5 & 10.8 \\
\hline $\begin{array}{l}\text { Perfect Organic Blend 4-4-4 } \\
\text { chicken manure (fall) }\end{array}$ & 423 & 274 & 7.3 & 18 \\
\hline $\begin{array}{l}\text { Pro-Pell-It! 13-0-0 bloodmeal at } \\
\text { planting }\end{array}$ & 423 & 290 & 7.2 & 15.6 \\
\hline $\begin{array}{l}\text { Stutzman Nutri-Rich 4-3-2 } \\
\text { chicken manure (fall) }\end{array}$ & 416 & 283 & 6.7 & 14.8 \\
\hline \multicolumn{5}{|l|}{$\begin{array}{l}\text { Untreated and conventional } \\
\text { fertilizer }\end{array}$} \\
\hline Untreated hand-weeded fallow & 358 & 261 & 6.1 & 7.6 \\
\hline $\begin{array}{l}\text { Urea fertilizer - } 75 \mathrm{lb} \text { N/acre } \\
\text { (planting) }\end{array}$ & 398 & 279 & 6.4 & 9.9 \\
\hline $\begin{array}{l}\text { Urea fertilizer - } 150 \mathrm{lb} \text { N/acre } \\
\text { (planting) }\end{array}$ & 405 & 285 & 6.6 & 12.2 \\
\hline Treatment effect $P$ value & 0.0001 & 0.3143 & 0.001 & 0.001 \\
\hline $\begin{array}{l}95 \% \text { confidence interval for mean } \\
\text { comparison }\end{array}$ & 34 & 36 & 0.6 & 5 \\
\hline
\end{tabular}

* Cull yield represents unmarketable tubers including those exhibiting green, rot, growth cracks, knobs and irregular shape. † Percentage of total yield.

‡ Information in parentheses represents time of incorporation for manures and amendments in 2014. and vetches. Grass cover crops were associated with the lowest leaf nitrogen, suggesting that the ability of grass decomposition to tie up nitrogen can be persistent. Visual growth differences were apparent throughout the winter wheat growing season; wheat in spring field peas and vetch cover crop treatments were taller and much greener than other treatments. This suggests that nitrogen release from legume cover crops can continue for more than 1 year and can potentially have cumulative effects in crop rotations.

\section{Amendments' influence on nitrogen}

Chicken manure amendments (composted chicken manure, Stutzman Nutri-Rich pellets and Perfect Organic Blend pellets) were the most effective fall-applied amendments for increasing soil nitrate levels at potato planting (table 3). Soil nitrate at potato planting in soil amended with chicken manure was greater than 75 pounds of nitrogen per acre (table 3), similar to levels in plots treated with field peas and vetches. Potato petiole nitrate levels for plots amended with chicken manure were over 19,000 ppm at early tuber bulking, similar to levels produced by many field peas and vetches. Potato petiole nitrate at early bulking for bloodmeal and soymeal amendments was similar to levels associated with both chicken manure and 150 pounds per acre of urea fertilizer (table 3).

Green waste compost applied at all rates, as well as composted steer manure, led to lower soil nitrate at potato planting than did chicken manure, and these amendments did not increase soil nitrate at potato planting compared to the fallow treatment (table 3). Green waste compost and steer manure did not increase potato petiole nitrate at early bulking and vine maturity (data not shown) compared to the fallow treatment, suggesting that nitrogen in these amendments mineralized too slowly for a single application to benefit a potato crop (table 3 ).

\section{Potato response to cover crops and amendments}

Potato establishment and early season vigor did not differ significantly among treatments, but differences in potato vigor were significant at row closure and tuber initiation (data not shown). Potato vigor differences were highly correlated $(r=0.86)$ with potato nitrate at early bulking. Treatments producing high potato petiole nitrate produced taller, greener potato plants than did treatments producing low potato petiole nitrate.

Russet Norkotah total potato yield, average tuber size and cull yield were influenced by cover crops and amendments (table 4) while Yukon Gold potato yield was similar for most treatments (data not shown). This trend was not surprising given that Russet Norkotah is more responsive to nitrogen fertilizer than Yukon Gold. For Russet Norkotah, vetch species (woollypod, hairy and chickling), chicken manures, steer manure, bloodmeal and soil protein fertilizer produced higher total potato yields than did the untreated fallow 
(table 4). These treatments, along with five field pea varieties, resulted in a larger average tuber size than did the untreated fallow (table 4).

Total yield for the treatment with 150 pounds per acre of urea fertilizer was similar to that produced with vetches, chicken manures and bloodmeal, suggesting that soil nitrogen availability was a primary factor in increasing potato yield (table 4). Nitrogen's important role is also supported by a strong positive correlation ( $r=0.873$ ) between total Russet Norkotah potato yield and potato petiole nitrate at early bulking. The $r$ value for this correlation equaled 0.656 when Russet Norkotah and Yukon Gold data were combined.

The only treatment-related effect on total Yukon Gold potato yield was that cover-cropping with spring wheat and fall triticale produced lower total yield than did cover-cropping with legumes (data not shown). Grass cover crop treatments led to numerically lower soil nitrogen at planting and lower potato petiole nitrate at early bulking, compared to the untreated fallow (table 3 ). This suggests that the low potato yield following grass cover crops could be due to nitrogen immobilization during potato growth and development.

Cover crop and amendment treatments did not cause a substantial increase in tubers with knobs or growth cracks in either Russet Norkotah or Yukon Gold (data not shown), but the percentage of cull potatoes based on total yield for Russet Norkotah differed among treatments (table 4). Both chicken manure treatments, as well as bloodmeal and soy protein, resulted in higher percentages of culls than did the untreated fallow. An increase in cull percentage often occurs as total yield increases, but Perfect Organic Blend chicken manure also produced a higher percentage of culls than did the treatment with 150 pounds per acre of urea fertilizer. All cover crop treatments led to a percentage of culls similar to or lower than was associated with the treatment with 150 pounds per acre of urea fertilizer (table 4).

Yukon Gold was chosen for the 2017 trials because Rhizoctonia black scurf and black dot tuber blemish, common problems for organic potato growers, are easy to see on yellow varieties. The severity of black scurf and black dot did not differ according to cover crop species, but in potatoes grown after spring-planted cover crops (averaged across cover crop species), 27\% exhibited black scurf - compared to $13 \%$ in potatoes grown after mid-summer and fall plantings of cover crops. On the other hand, spring plantings of cover crops (averaged across species) led to lower black dot severity on tubers than did mid-summer plantings (data not shown).

\section{Grower decisions}

Economic issues play a major role in the feasibility of using legume cover crops to boost soil nitrogen in a crop rotation. Organic growers must consider the opportunity cost involved in growing cover crops instead of a cash crop as well as the cost of applying an amendment such as chicken manure. The economic analysis required to weigh all benefits and lost opportunity costs is complex, and beyond the scope of this study, but a comparison of monetary costs shows that cover crop production is more expensive than synthetic fertilizer, similar to applying chicken manure and less expensive than applying bloodmeal and soy meal. The average cost of bulk urea fertilizer from local suppliers in Northern California in 2018 was $\$ 365$ per ton, or $\$ 60$ to supply one acre with 150 pounds of nitrogen (R. Wilson, unpublished data). The average cost of bulk dried poultry manure from local suppliers in Northern California was $\$ 145$ per ton, or $\$ 272$ dollars to supply one acre with 150 pounds of nitrogen (R. Wilson, unpublished data). The cost of bulk bloodmeal and soy meal represented a nitrogen cost of greater than $\$ 3.40$ per pound, or over $\$ 500$ to supply one acre with 150 pounds of nitrogen. The cost of certified organic bloodmeal, packaged in 50-pound bags, was greater than $\$ 7$ per pound of nitrogen, or more than $\$ 1,000$ to supply one acre with 150 pounds of nitrogen. The total cost of field pea and vetch production is estimated at \$175 dollars per acre, including the cost of seed, planting, irrigation, management and incorporation (R. Wilson, unpublished data).

\section{Cover crops versus amendments}

Vetch, field peas, bloodmeal, soy meal and chicken manure, because they produced potato yields and potato petiole nitrate similar to those produced in plots treated with 150 pounds per acre of urea fertilizer (tables 3 and 4), were feasible alternatives to synthetic fertilizer. Whether organic producers favor cover crops or chicken manure as a nitrogen source depends on several factors, including land availability and the opportunity to grow cash crops. Producers who grow high-value cash crops requiring a full growing season may favor amendments because they can be quickly applied after harvest or before planting. Producers with idle land or with time between cash crops during the growing season may prefer cover crops, as many legumes in this study added over 150 pounds of nitrogen per acre and provided multi-season carry-over of soil nitrogen, and also offer protection from soil erosion. For hay producers, it's extremely important to leave aboveground biomass from legume cover crops in place, instead of haying the residue, because most added nitrogen is contained in legumes' leaves and shoots rather than their roots. Regardless, both options offer benefits in soil health, and in our study the added nitrogen in both cases broke down into mineralized form in adequate amounts to meet early-season and late-season potato nitrogen needs. The economic benefit of using cover crops and chicken manure is more difficult to justify in conventional potatoes because, in our research, both practices entail higher costs and 
greater difficulty of application than synthetic fertilizer, which produced similar yields.

For organic potato production, using either grass cover crops or a one-time application of compost to increase soil nitrogen is difficult to justify economically. In our research, these treatments had a neutral or negative effect on soil nitrogen compared to fallow treatments. Organic nitrogen in these treatments failed to convert into mineralized form in adequate amounts to increase either potato yield or yield of wheat planted the year after potatoes. Mustard, arugula and radish had a neutral-to-positive effect on potato yield and nitrogen. Several Brassica species have also been shown to have biofumigation properties, although a reduction in soilborne potato diseases Rhizoctonia solani, Colletotrichum coccodes and Verticillium wilt was not evident in this study.
Fallowing for an entire year, starting in spring the year before growing potatoes, is another option that growers with idle land or limited water can consider. In this research, the spring fallow treatment resulted in mineralized nitrogen at potato planting similar to or higher than levels that resulted from the summer fallow and fall fallow treatments (table 3). In potatoes, the spring fallow treatment produced petiole nitrate at early bulking $(19,900 \mathrm{ppm})$ similar to that produced by a treatment with 150 pounds per acre of urea fertilizer following barley $(23,600 \mathrm{ppm})$. The additional nitrogen in the spring fallow treatment was likely related to natural mineralization of soil organic matter, as organic matter in Tulelake soils is naturally high (within a range of $4 \%$ to $8 \%$ ).

TABLE 5. Decision support for cover crops

\begin{tabular}{|c|c|c|c|c|}
\hline Land use objective & $\begin{array}{l}\text { Spring } \\
\text { planting* }\end{array}$ & $\begin{array}{l}\text { Mid-summer } \\
\text { planting* }\end{array}$ & $\begin{array}{l}\text { Fall } \\
\text { planting* }\end{array}$ & Comments \\
\hline Increase soil N & +++ & ++ & ++ & $\begin{array}{l}\text { Choose } \mathrm{N} \text {-fixing cover crop. Manage as a green manure. Field peas and } \\
\text { vetch are suitable for all planting times. Allow at least } 4 \text { weeks before } \\
\text { growing cash crop. }\end{array}$ \\
\hline Minimize loss of soil N & + & ++ & ++ & $\begin{array}{l}\mathrm{N} \text { from spring cover crop has the highest potential to be lost over the } \\
\text { winter, although results from this study did not show significant winter } \\
\text { losses. Wheat grown the year after potatoes captured soil } \mathrm{N} \text { from spring } \\
\text { cover crops grown } 2 \text { years prior. }\end{array}$ \\
\hline Scavenge soil nutrients & +++ & ++ & +++ & $\begin{array}{l}\text { Deep-rooted cover crops are effective at capturing nutrients if soil } \\
\text { testing indicates elevated levels located below the crop root zone. } \\
\text { Consider manure application if phosphorus or potassium is deficient at } \\
\text { all soil depths. Avoid double-cropping non-legume crops if soil } \mathrm{N} \text { is low. }\end{array}$ \\
\hline Suppress weeds & +++ & + & ++ & $\begin{array}{l}\text { Choose a vigorously growing cover crop. Vetch, field peas, mustard } \\
\text { and spring and fall small grains provided good weed suppression. Poor } \\
\text { cover crop growth or overirrigation can lead to an increase in weeds } \\
\text { the following season. Mid-summer plantings resulted in elevated weed } \\
\text { populations in potato for multiple species. }\end{array}$ \\
\hline Build soil organic matter & +++ & +++ & +++ & $\begin{array}{l}\text { Choose cover crop with high biomass. Cover crops must be grown for } \\
\text { several years to produce a significant change in soil organic matter. }\end{array}$ \\
\hline Prevent soil erosion & + & ++ & +++ & $\begin{array}{l}\text { Wind and water erosion is most problematic in winter and early spring } \\
\text { in northeast California. Don't incorporate aboveground residue if } \\
\text { preventing soil erosion is a high priority. }\end{array}$ \\
\hline Minimize need for irrigation & ++ & + & +++ & $\begin{array}{l}\text { Spring and fall cover crops take advantage of natural precipitation } \\
\text { events and offer the best chance of success on dry lands. Irrigation } \\
\text { to establish cover crops is recommended if significant rainfall is not } \\
\text { predicted. Mid-summer plantings require irrigation due to low summer } \\
\text { rainfall. }\end{array}$ \\
\hline $\begin{array}{l}\text { Potential for double- } \\
\text { cropping }\end{array}$ & + & ++ & ++ & $\begin{array}{l}\text { The region's short growing season limits opportunities to double-crop. } \\
\text { In this research, spring and summer plantings of cover crops took } 70 \text { to } \\
80 \text { days to reach the flowering stage. It is recommended that growers } \\
\text { allow at least } 4 \text { weeks after cover crop incorporation before planting a } \\
\text { cash crop. }\end{array}$ \\
\hline Increase potato yield & +++ & ++ & ++ & $\begin{array}{l}\text { Spring-planted cover crops with a summer fallow period resulted in the } \\
\text { highest potato yield, averaged across cover crop species. }\end{array}$ \\
\hline Suppress potato diseases & + & + & + & $\begin{array}{l}\text { Many cover crops are hosts of plant diseases. It is important to allow } \\
\text { at least } 4 \text { weeks after cover crop incorporation before planting a cash } \\
\text { crop to prevent the cover crop from serving as a green bridge for crop } \\
\text { diseases. In this research, cover crops had a neutral effect on potato } \\
\text { diseases when compared to the fallow treatment. Fall cover crops had } \\
\text { the lowest level of Rhizoctonia on tubers. }\end{array}$ \\
\hline
\end{tabular}




\section{Cover crop planting times}

Land managers who decide to grow cover crops often ask what time of year is optimal for planting them. The answer depends on land use objectives and the desired cover crop species. Table 5 is a decision support tool to help land managers weigh the benefits of different cover crop planting times. In this research, spring planting averaged across species resulted in fewer weeds, more tubers per plant and higher potato yields than did mid-summer and fall plantings (data not shown). Midsummer and fall plantings resulted in slightly less $R h i$ zoctonia black scurf than did spring plantings. These planting times also offer greater flexibility for doublecropping than does spring planting.

\section{Research recommendations}

Cover crops and amendments offer growers an effective way to increase mineralized soil nitrogen for organic potato production. In this research, use of both cover crops and amendments resulted in potato yields and potato quality similar to those achieved through use of conventional nitrogen fertilizer, without unacceptable outcomes related to pests. Results related to nitrogen are likely transferrable to other nitrogen-demanding crops grown in northeast California, including small grains and onions. Additional research is needed to address benefits and disadvantages involved in repeated use of cover crops and amendments over the long term (5 to 10 years). Research into long-term effects would be beneficial because many organic producers keep land in organic status for more than 5 years before rotating it back to conventional production. Research that examines organic fertilizer options for supplementing nutrients other than nitrogen is also needed. This is especially true for forage crops like alfalfa because such crops remove from the soil large amounts of phosphorus and potassium that are not returned after hay harvest. CA
R. Wilson is UC Cooperative Extension (UCCE) Farm Advisor at UC ANR Intermountain Research and Extension Center (Intermountain REC); D. Culp is Principal Superintendent of Agriculture at Intermountain REC; S. Peterson is Senior Farm Machinery Mechanic at Intermountain REC; K. Nicholson is Staff Research Associate at Intermountain REC; and D. Geisseler is UCCE Specialist in Nutrient Management in the Department of Land, Air and Water Resources at UC Davis.

\section{References}

Alva A. 2004. Potato nitrogen management. J Veg Crop Prod 10(1):97-132. https://doi. org/10.1300/J068v10n01_10 [CDFA] California Department of Food and Agriculture. 2015 California fertilization guidelines: potatoes. https://apps1. cdfa.ca.gov/FertilizerResearch/ docs/Potato.html (accessed Dec. 1, 2018)

Duru M. 1987. Effect of animal manure on phosphorus and potassium content of herbage. In: Animal Manure on Grassland and Fodder Crops: Fertilizer or Waste? Developments in Plant and Soil Science (30). Van Der Meer HG, Unwin RJ, Van Dijk TA, Ennik GC (eds.). Dordrecht: Springer. p. 351-3. https://doi. org/10.1007/978-94-009-3659 1_36

Fageria NK, Baligar VC, Bailey BA. 2005. Role of cover crops in improving soil and row crop productivity. Commun Soil Sci Plan 36(19-20):2733-57. https:// doi.org/10.1080/00103620500 303939

Finckh MR, Schulte-Geldermann E, Bruns C. 2006. Challenges to organic potato farming: disease and nutrient management. Potato Res 49(1):27-42. https://do org/10.1007/s11540-006-9004-3
Gimsing AL, Kirkegaard JA. 2009. Glucosinolates and biofumigation: fate of glucosinolates and their hydrolysis products in soil. Phytochem Rev 8(1):299-310. https://doi.org/10.1007/s11101008-9105-5

Hartz TK, Mitchell JP, Giannini C. 2000. Nitrogen and carbon mineralization dynamics of manures and composts. HortScience 35(2):209-212. https://journals. ashs.org/hortsci/view/journals/ hortsci/35/2/article-p209.xml

Hemayati SS, Akbar MJ, Ghaemi A, Fasahat P. 2017. Efficiency of white mustard and oilseed radish trap plants against sugar beet cyst nematode. Appl Soil Ecol 119:192-6. www.science direct.com/science/article/pii/ S092913931730392X

Kaspar TC, Singer JW. 2011. The use of cover crops to manage soil. US Department of Agriculture: Agricultural Research Service. http://digitalcommons. unl.edu/cgi/viewcontent.cgi? article $=2387 \&$ context $=$ usdaar sfacpub

Klonsky K, Greene CR. 2005. Widespread adoption of organic agriculture in the US: Are market-driven policies enough? American Agricultural Economics Association Annual Meeting, July 24-27, 2005. Providence, Rhode Island. http://ageconsearch.umn.edu/record/19382 files/sp05kl05.pdf
Kuo S, Sainju UM. 1997. Winter cover cropping influence on nitrogen in soil. Soil Sci Soc Am J 61(5):1392-9.

Kuo S, Sainju UM. 1998. Nitrogen mineralization and availability of mixed leguminous and non-leguminous cover crop residues in soil. Biol Fert Soils 26(4):346-53.

Lang NS, Stevens RG, Thomton RE, et al. 1999. Potato nutrient management for Central Washington. Pullman, Washington: Washington State University Cooperative Extension. Publication EB1871. https://research.wsu-

libs.wsu.edu/xmlui/bitstream/ handle/2376/6896/eb1871 pdf? sequence=1\&isAllowed =y Larkin RP, Griffin TS, Honeycutt CW. 2010. Rotation and cover crop effects on soilborne potato diseases, tuber yield and soil $\mathrm{mi}$ crobial communities. Plant Dis 94(12):1491-1502. https://do org/10.1094/PDIS-03-10-0172

Larney FJ, Blackshaw RE. 2003. Weed seed viability in composted beef cattle feedlot manure. J Environ Qual 32(3):1105-13. www.ncbi.n/m.nih.gov/ pubmed/12809312

Lazicki P, Geisseler D, Horwath WR. 2016. Potato production In California. California Department of Food and Agriculture. https://apps1.cdfa.ca.gov/

FertilizerResearch/docs/

Potato_Production_CA.pdf
Lynch DH, Sharifi M, Hammermeister A, Burton DL. 2012. Nitrogen management in organic potato production. In: Sustainable Potato Production: Global Case Studies. He Z et al. (eds.). Berlin/Heidelberg: Springer. https://link.springer. com/content/pdf/10.1007/97894-007-4104-1_12.pdf

Möller K. 2018. Soil fertility status and nutrient input-output flows of specialised organic cropping systems: a review. Nut Cycl Agroecosys 112(2):147-64. https://doi.org/10.1007/s10705018-9946-2

Sharma-Poudyal D, Paulitz

TC, du Toit LJ. 2016. Timing of glyphosate applications to wheat cover crops to reduce onion stunting caused by Rhizoctonia solani. Plant Dis 100(7):1474-81. https:// apsjournals apsnet.org/doi/ pdf/10.1094/PDIS-10-151234-RE

Sincik M, Turan ZM, Göksoy AT. 2008. Responses of potato (Solanum tuberosum L.) to green manure cover crops and nitrogen fertilization rates. Am J Potato Res 85(5):390-1.

https://link.springer.com/ article/10.1007/s12230-008 9043-1
Stark J, Westermann D, Hopkins B. 2004. Nutrient management guidelines for Russet Burbank potatoes. Moscow, Idaho: University of Idaho Cooperative Extension. Bulletin 840. www extension.uidaho.edu/ publishing/pdf/BUL/BUL0840. pdf

Sullivan DM, Andrews ND. 2012. Estimating plant-available nitrogen release from cover crops. Corvallis, Oregon: Pacific Northwest Extension. http:// ir.library.oregonstate.edu/xmlui/ bitstream/handle/1957/34720/ pnw636.pdf

[USDA] U.S. Department of Agriculture. 2017. Certified organic survey: 2016 summary. www. nass.usda.gov/Publications/ Todays_Reports/reports/census17.pdf

Whalen JK. 2014. Managing soil biota-mediated decomposition and nutrient mineralization in sustainable agroecosystems. Adv Agriculture. Article 384604. https://hindawi.com/journals/ aag/2014/384604

Wyland LJ, Jackson LE, Chaney WE, et al. 1996. Winter cover crops in a vegetable cropping system: impacts on nitrate leaching, soil water, crop yield, pests and management costs. Agr Ecosyst Environ 59:1-17. https://pdfs. semanticscholar.org/b324/ d3f8a27f8128b3d062fa4905b66fdea53612.pdf 


\section{Virus surveys of commercial vineyards show value of planting certified vines}

In the North Coast wine-growing region, mixed infections were predominant in older vineyards, while recently planted certified vines did not have mixed infections.

by Kari L. Arnold, Neil McRoberts, Monica L. Cooper, Rhonda Smith and Deborah A. Golino

\section{Abstract}

Viruses are of great concern in vineyards. They cost the California wine grape industry as much as $\$ 91,661$ per acre over the life of a vineyard, according to a 2015 economic study of the North Coast wine-growing region. As a first step toward managing viruses, growers are encouraged to plant certified material regulated by the California Grapevine Registration and Certification program. There are risks in sourcing plant material from stocks that are not subject to the same level of regulation. We surveyed vineyards of varying ages for eight common viruses to demonstrate the value of selecting certified material for new plantings.
Author Kari Arnold examines a virus-positive vine at a UC Davis research project. Viruses cost the California wine grape industry as much as $\$ 91,661$ per acre over the life of a vineyard. Planting certified material regulated by the California Grapevine Registration and Certification program is a first step toward managing viruses.

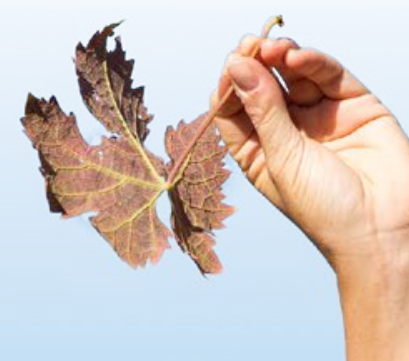

G rapevines have the highest number of viruses and virus-like diseases ever discovered in a single crop (Martelli 2014), and they may cost California wine grape growers as much as $\$ 91,661$ per acre over the life of a vineyard (Ricketts et al. 2015) by affecting yield, color, sugar and other qualitative parameters (Goheen and Cook 1959). Some viruses are spread by insects and nematodes (Golino et al. 2002; Raski and Hewitt 1960), but human activities such as the propagation of infected material also distribute viruses into vineyards. Viruses are graft transmissible, meaning they can move from scion to rootstock, or from rootstock to scion during topworking (Alley and Golino 2000; Olmo 1951).

Online: https://doi.org/10.3733/ca.2019a0006

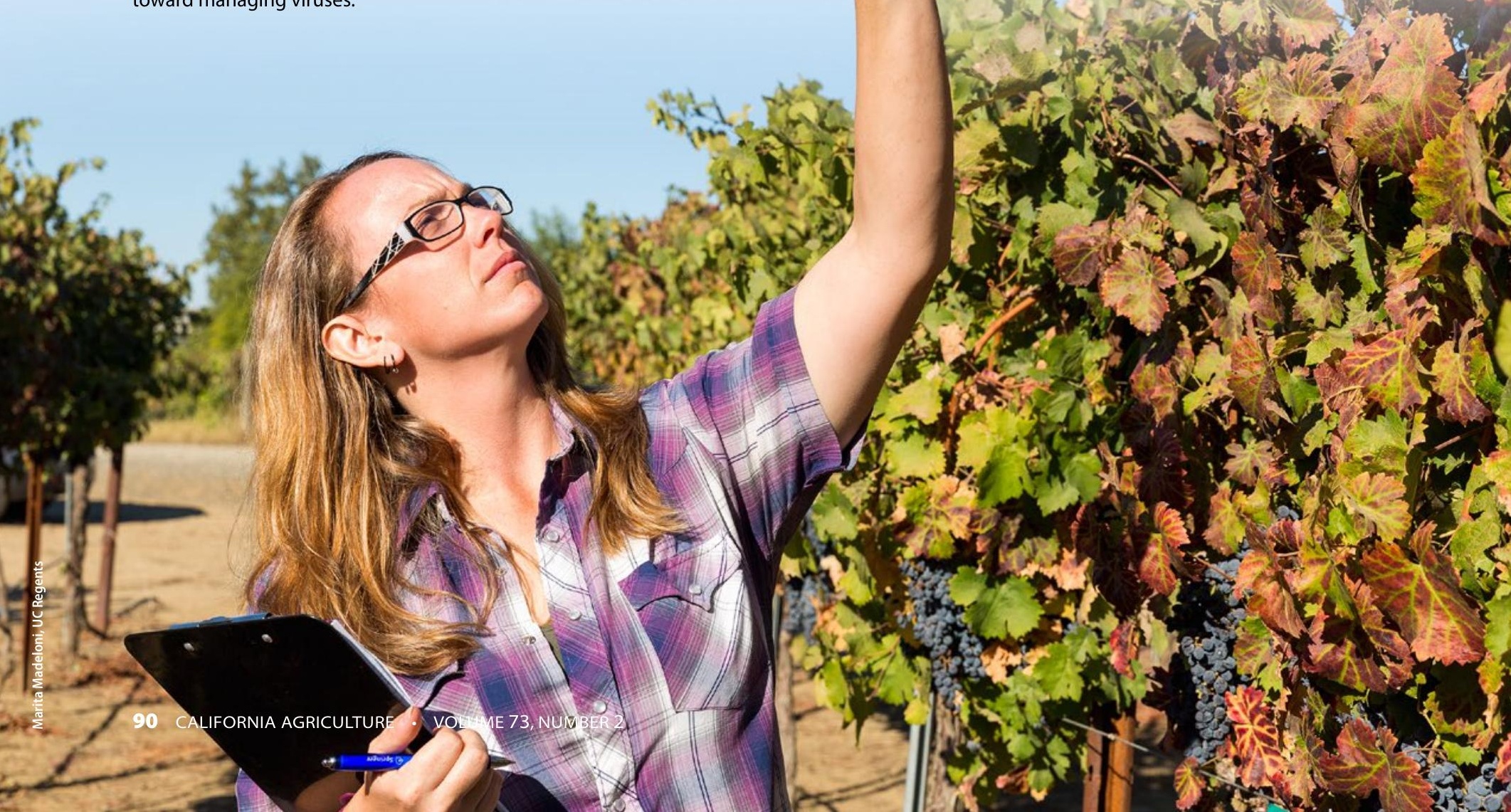




\section{CGR\&C program}

The first step in virus management is sourcing virusscreened material. Under the auspices of the California Grapevine Registration and Certification (CGR\&C) program (www.cdfa.ca.gov/plant/pe/nsc/nursery/ grapevine.html), virus-screened material is provided through a systematic supply chain regulated by the California Department of Food and Agriculture (CDFA): CGR\&C-certified vines are derived from registered nursery increase blocks where samples are collected and screened for viruses on a rotational basis and maintained in accordance with CDFA guidelines; the vines in registered nursery increase blocks are derived from foundation material at the Foundation Plant Services (FPS) department at UC Davis, where every vine is screened on a rotational basis and maintained in accordance with CDFA guidelines (Golino et al. 2017). Since its establishment in the 1950s, the CGR\&C program has grown to provide an economic benefit of up to $\$ 50$ million per year for the North Coast region alone (Fuller et al. 2015).

Virus screened, however, does not mean virus free; unknown viruses may not be detected and some viruses may not have a negative impact on the crop ( $\mathrm{Al}$ Rwahnih, Rowhani et al. 2015; Al Rwahnih et al. 2013; Al Rwahnih et al. 2016).

Screening activities occur at different points in the supply chain. The initial screening of a grapevine selection is a series of biological assays designed to detect disease symptoms related to certain detrimental virus diseases (Rowhani et al. 2005). These assays require the grafting of the selection onto healthy indicator vines. If certain viruses are present in the selection, the indicator vines will indicate virus infection by developing disease symptoms (Rowhani et al. 2005). For example, red, rolling leaves in the Cabernet Franc indicator assay is indicative of grapevine leafroll disease.

Material that passes the initial screening is tested by DNA analysis to ensure it is true to type, then advanced to foundation status and planted into the foundation vineyard at FPS. That vineyard is subject to spring and fall inspections, and every vine is tested on a rotational basis using PCR (polymerase chain reaction) assays and ELISA (enzyme linked immunosorbent assay) because viruses can enter the vineyard by way of insects and other vectors.

Registered increase block material at commercial nurseries originates from foundation material, and therefore it does not need to be subjected to biological assays. However, virus-specific assays such as PCR and ELISA are used to repeatedly sample the blocks, and visual inspections are made to monitor the virus status of the plant material. PCR and ELISA are reliable assays, but their specificity is a drawback: They give positive results only for known viruses and virus strains, not for unknown viruses. When grapevine red blotch virus (GRBV) and grapevine Pinot gris virus (GPGV) were recently discovered, they had to be sequenced before researchers could construct new diagnostic assays to detect them (Al Rwahnih et al. 2013; Al Rwahnih et al. 2016).

GRBV was discovered in 2013 (Al Rwahnih et al. 2013), but the testing of a dried leaf sample collected from Sonoma County and stored in the UC Davis herbarium for 70 years dates the presence of GRBV in California as far back as 1940 (Al Rwahnih, Rowhani et al. 2015), when that leaf sample was first collected by Dr. Harold Olmo, a UC Davis professor of viticulture. GRBV shares common symptoms with grapevine leafroll disease, which is caused by multiple grapevine leafroll associated viruses (GLRaV-1, -2, -3, -4 and -7 ). These virus diseases were likely detected as a single disease by the biological assay due to similar symptomology. Vine selections showing leafroll-like symptoms, whether they were infected with GRBV or GLRaVs, would not have advanced into the foundation vineyard at FPS. Yet, if GRBV were somehow introduced to a registered increase block, the virus could go undetected because a more virus-specific screening assay like ELISA or PCR for GLRaV-3 would not detect it.

Grower concern, as well as recent work involving economic impacts (Ricketts et al. 2017), led to the addition of GRBV to the regulations of the CGR\&C

Right, the initial screening of a grapevine selection requires the grafting of the selection onto healthy indicator vines. If certain viruses are present in the selection, the indicator vines will develop disease symptoms. Material that passes initial screenings is tested by virus-specific assays such as PCR and ELISA (below, ELISA plate with sample).

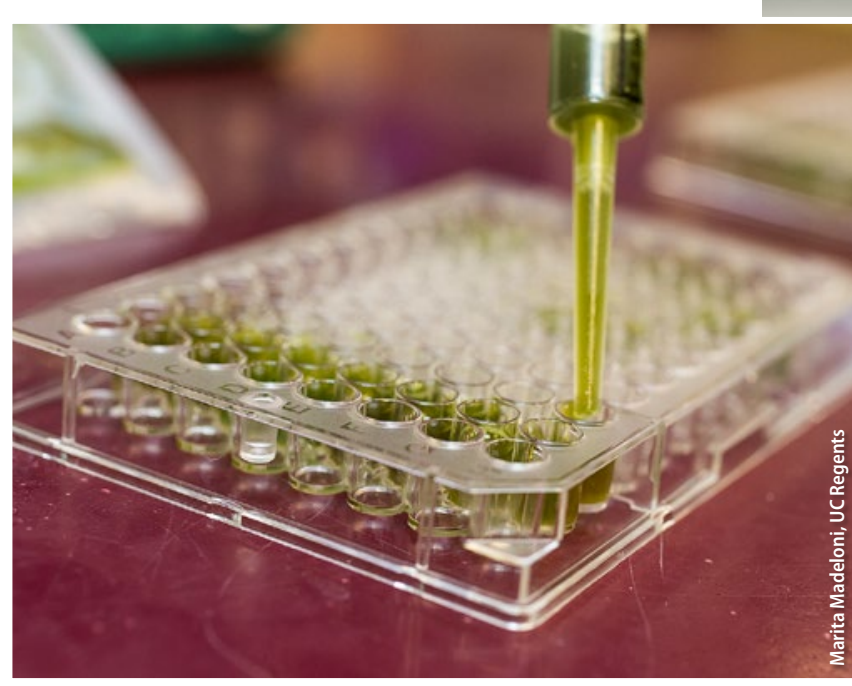


program and the addition of PCR detection techniques because GRBV is not detectable by ELISA methods. Using PCR-based assays increases efficiency by screening a sample for multiple viruses at once and enhances reliability by screening registered increase blocks for viruses not previously targeted. The updated sampling protocol also provides analytics to measure success and facilitate future improvements (Arnold et al. 2017; McRoberts et al. 2003). With the support of industry stakeholders, FPS has also invested in genetic sequencing technology to improve unknown virus detection in plant material (Al Rwahnih, Daubert et al. 2015).

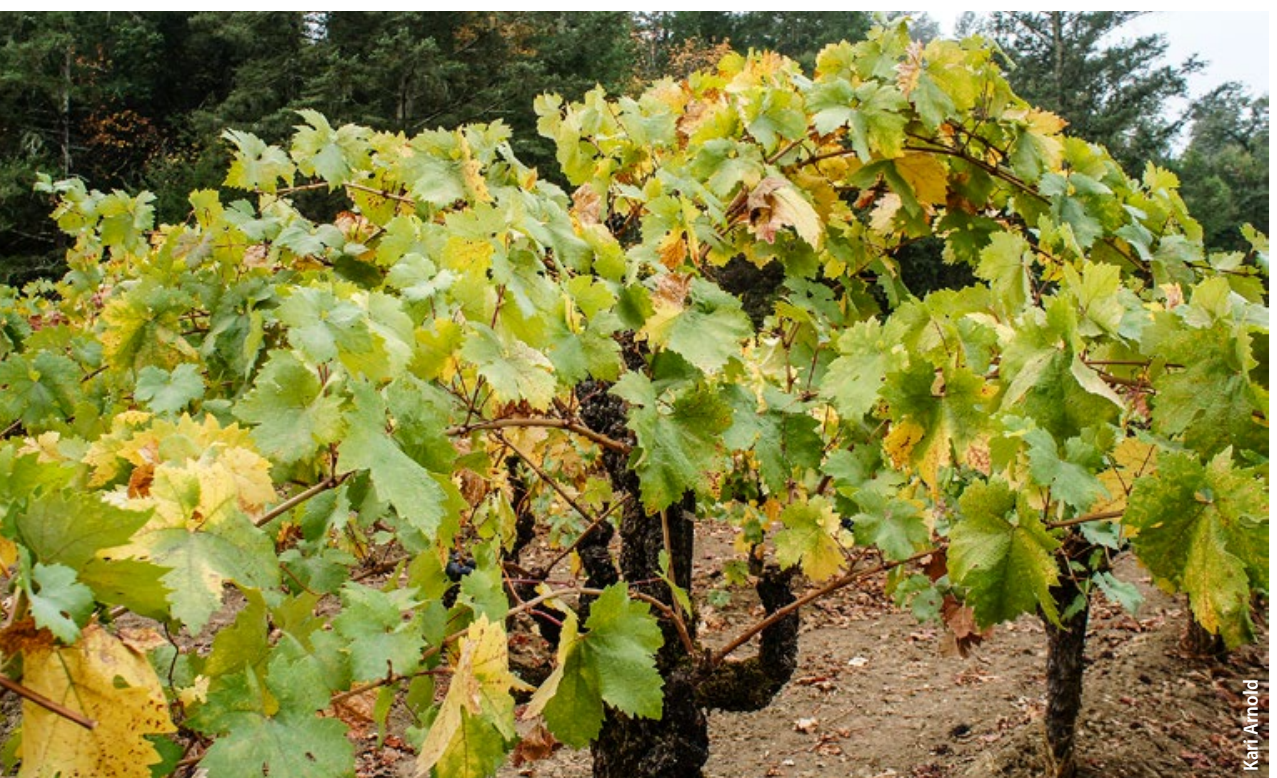

Zinfandel grafted to St. George rootstock appears healthy, although it is infected with GLRaV-2 and grapevine virus $A$ and $B$.
There are great risks in selecting material for new vineyard plantings from sources that are not subject to the same level of regulation as the CGR\&C program. Multiple viruses spread naturally in the vineyard by way of insects and nematodes, and the longer a vine remains exposed to nearby infected vines and their virus vectors, the more likely that vine is to be infected (Arnold et al. 2017). For example, mealybugs and some scale insects spread GLRaV-3, and dagger nematodes (Xiphinema index) spread grapevine fanleaf virus (GFLV). To demonstrate the risks of not using certified planting material, we surveyed commercial wine grape

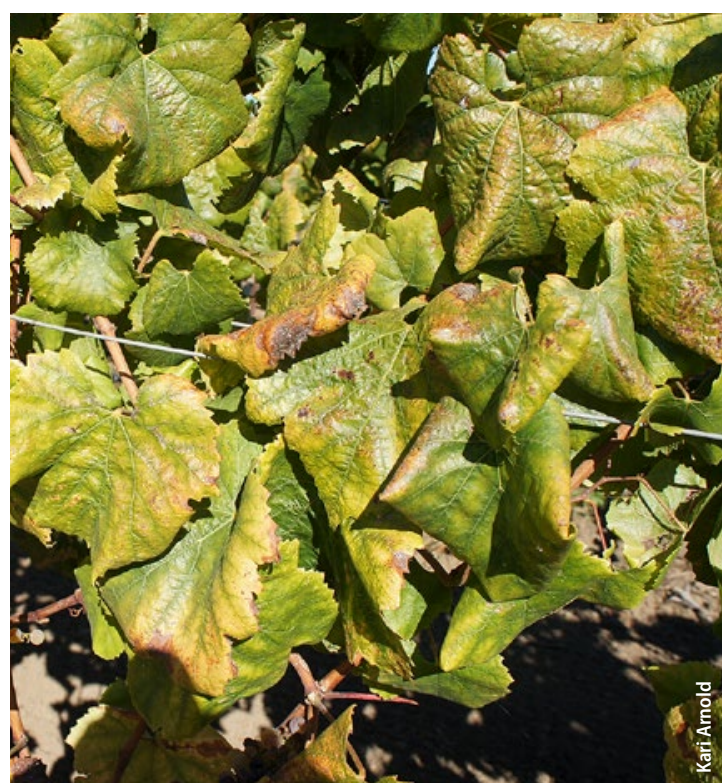

Chardonnay infected with both GLRaV-3 and GRBV.
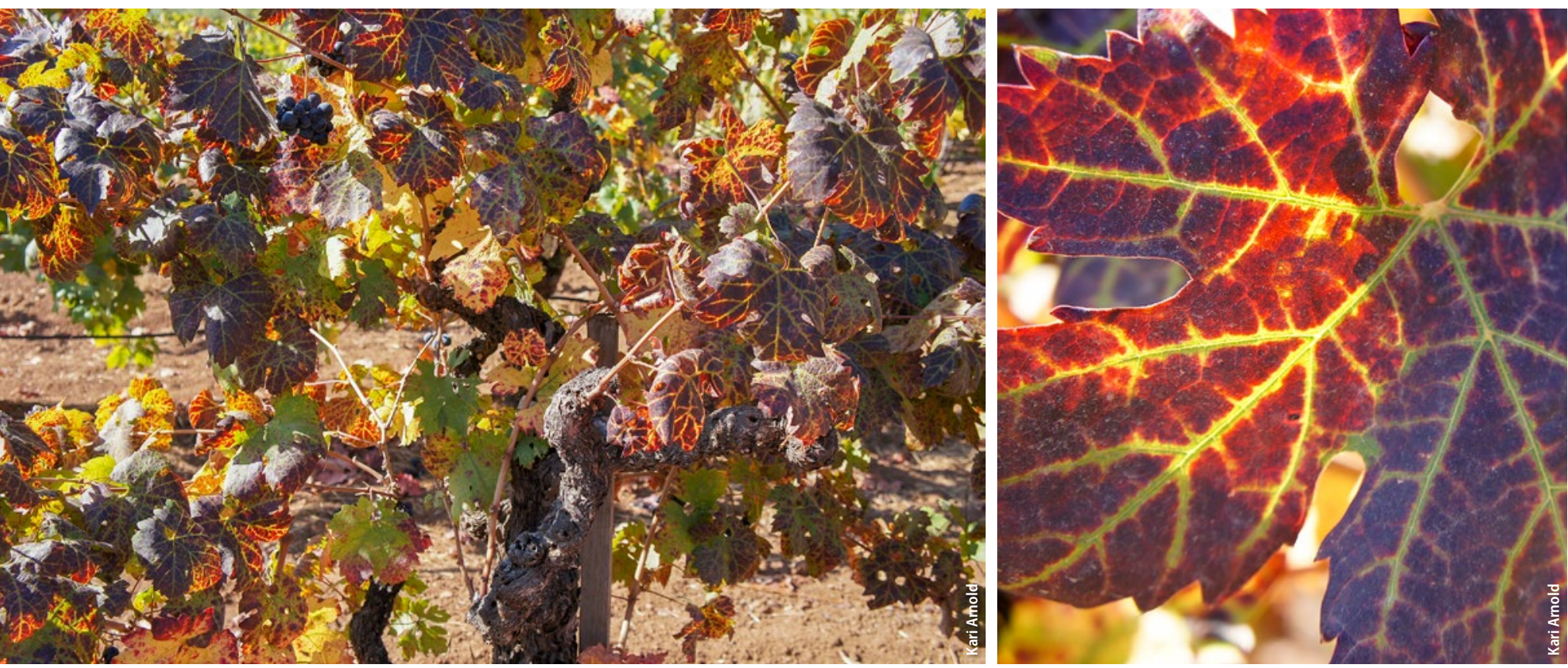

Red variety infected with GLRaV-2 andGLRaV-3 (left), and grapevine viruses A and B (leaf closeup, right). 
vineyards of varying age and origin and screened for viruses regulated by the CGR\&C program.

\section{Survey of 24 vineyards}

We selected vineyards for the survey based on the history of grapevine material in the North Coast region of California and defined them by planting year range: 1880-1980, 1981-1995, 1996-2010 and 2011-2014 (table 1). We surveyed 24 vineyards in the Carneros, Oakville, Rutherford, Calistoga and St. Helena viticulture areas in the Napa Valley and the Healdsburg region of Sonoma County to account for multiple regions.

We collected five to 15 vine samples, including both white- and red-fruited varieties, from 27 to 29 randomly selected blocks in each planting year range. Sample size was adjusted to account for variability in block size, which ranged from 2 to 20 acres. Vines expressing symptoms and also vines not expressing symptoms were sampled. A total of 980 samples were collected from 112 blocks. Survey collection began in August 2014 and continued for 3 months. We sampled in a W pattern in the field to account for spatial patchiness in the incidence of the viruses (Hughes and Madden 1992, 1993; Madden et al. 2007).

We tested each sample individually using molecular assays (quantitative real-time polymerase chain reaction, or qRT-PCR) to acquire accurate diagnostic information. We tested for GLRaV-1, -2 and -3, GRBV, grapevine virus $A$ and $B$ (GVA, GVB), grapevine fleck virus (GFkV) and GFLV. Samples consisted of either four petioles or four canes (equivalent when using qRT-PCR for viruses in this survey) from each individually tested vine. Primers used were courtesy of FPS (Klaassen et al. 2011; Weber et al. 2002).

The survey data were subjected to three analyses to compare samples originating from older vineyards to those originating from vineyards planted between 2011 and 2014 with CGR\&C program material. First, we analyzed the percentage of positive vines for each virus tested in each planting year range. Second, we performed a distributional analysis (Madden et al. 2007). Third, we analyzed the presence of mixed infections in the surveyed vines because many viruses regulated by the CGR\&C program may exist as mixed infections in a single vine. Some viruses are synergistic (interacting with one another and producing dramatic increases in symptoms), potentially leading to greater economic impact (Syller 2012).

\section{Value of certified stock confirmed}

At the block level, the percentage of positive vines for each virus tested ranged from $0 \%$ to $100 \%$; each block contained only a subset of the eight viruses. On average, more viruses were present in old material than in recently planted certified material (fig. 1).

The distributional analysis (fig. 2) shows the frequency of different levels of infection. For example, in
TABLE 1. Planting years and history of surveyed vineyard blocks

\begin{tabular}{|c|c|}
\hline $\begin{array}{l}\text { Planting year } \\
\text { range }\end{array}$ & Surveyed vineyard blocks \\
\hline 1880-1980 & $\begin{array}{l}\text { Many blocks replanted on AXR-1 and St. George in response to an epidemic } \\
\text { of grape phylloxera (Daktulosphaira vitifoliae), an aphidlike root pest (Wolpert } \\
\text { et al. 1994). }\end{array}$ \\
\hline 1981-1995 & $\begin{array}{l}\text { Many blocks replanted due to the failure of AXR-1 to phylloxera biotype B } \\
\text { (Wolpert et al. 1994). }\end{array}$ \\
\hline 1996-2010 & $\begin{array}{l}\text { AXR-1 failure-related replacement vines planted on rootstocks of American } \\
\text { species parentage after viruses in infected scion mother material expressed } \\
\text { symptoms previously masked by AXR-1 and St. George. }\end{array}$ \\
\hline $2011-2014$ & $\begin{array}{l}2008-2009 \text { recession resulted in many blocks in fallow, which have since } \\
\text { been planted/replanted with certified material. }\end{array}$ \\
\hline
\end{tabular}

the 1880-1980 planting year range, seven blocks had $80 \%$ infection by GLRaV-2. In that year range, there was a relatively even number of blocks infected at the different percentage levels for the eight viruses. This is considered a uniform or even distribution.

Infection in the later planting year ranges was not evenly distributed at different levels; most blocks had low incidence, and in the planting year range 20112014 the incidence was mostly zero. The incidences in certified material planted in year range 2011-2014 of GFLV, GLRaV-3, GVA and GRBV (fig. 2) were likely related to spread by insects and nematodes (Bahder et al. 2016; Golino et al. 2002; Raski and Hewitt 1960; Tsai et al. 2008) and the recent discovery of GRBV (Al Rwahnih et al. 2013).

Of the vines tested from vineyards planted between 1880 and $1980,85 \%$ contained mixed infections. None of the vines in the 2011-2014 planting year range

\section{The benefit of using certified material sourced from virus-tested, monitored vines is seen in the absence of mixed infections.}

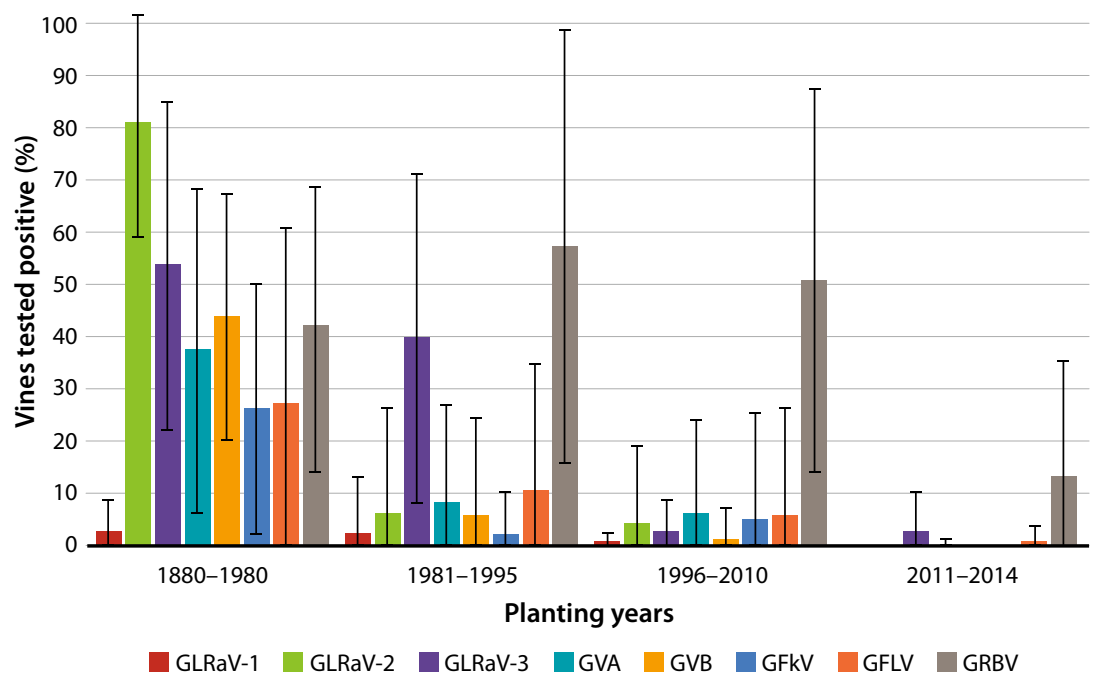

FIG. 1. Average percentage of positive vines for each virus tested in each planting year range. Standard error bars are in black. 

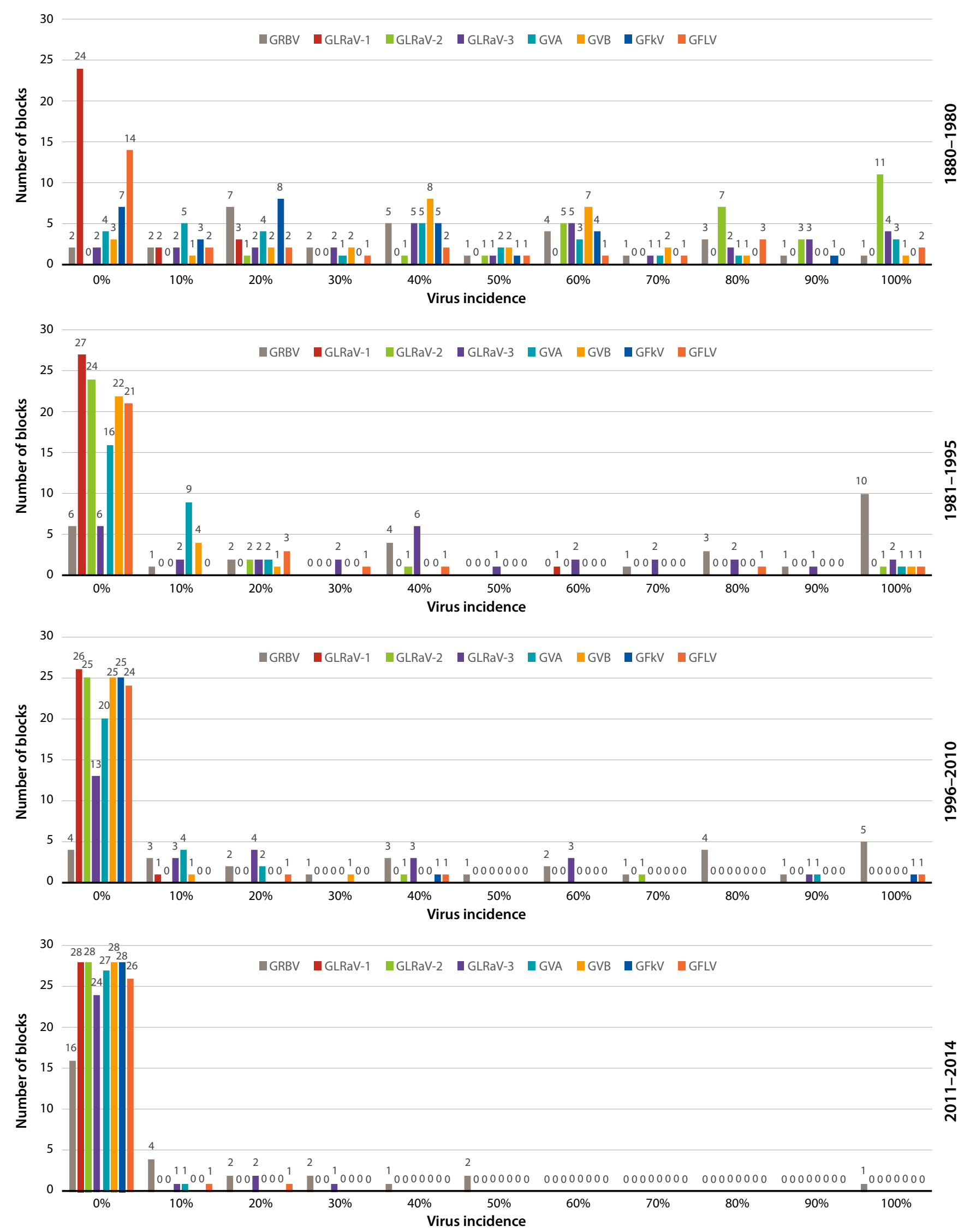

FIG. 2. Distributional analysis showed an even distribution of viruses in material planted between 1880 and 1980, while certified material planted between 2011 and 2014 showed predominantly zero infection. The few viruses present in certified material were viruses with known vectors and GRBV, which was unregulated until 2013. 

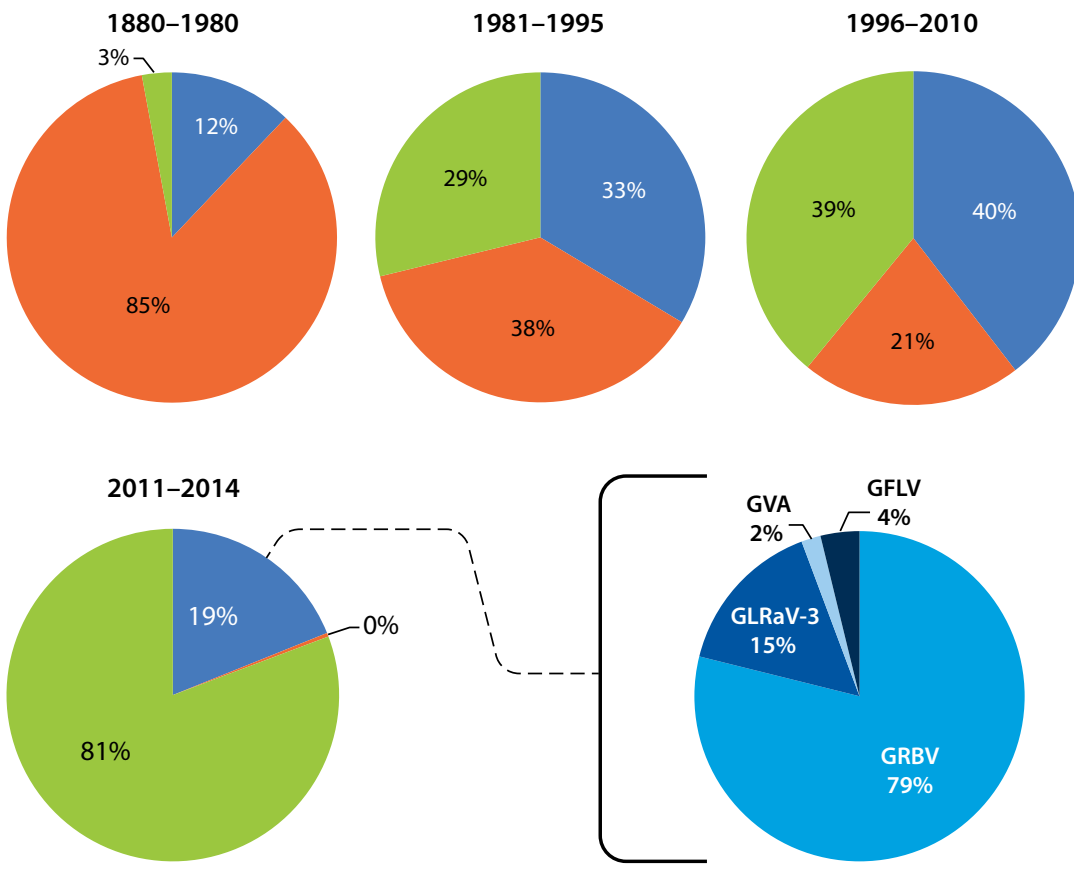

Mixed infections

Single infections

Virus negative

FIG. 3. Mixed infections were predominant in older vineyards. Recently planted certified vines did not have mixed infections. Only $19 \%$ of recently planted certified material had single infections and of those $79 \%$ were GRBV, a recently discovered virus, $15 \%$ were GLRaV-3, an insect transmitted virus and $4 \%$ were GFLV, a nematode-transmitted virus. contained mixed infections (fig. 3). More than $80 \%$ of the certified vines tested negative for all eight viruses, and the remaining approximately $20 \%$ of vines contained single virus infections. Of those single infections in new material, nearly $80 \%$ tested positive for GRBV, which was not regulated by the CGR\&C program until 2013 , and $15 \%$ tested positive for GLRaV-3, which is spread by mealybugs and scale insects.

The results of this survey suggest that there are risks associated with the use of nonregulated vineyard material for establishment of new vineyards. Without regulated sampling, screening and monitoring provided by the CGR\&C program as well as the research involved in discovering viruses, future planting material would decline as viral infections spread. CA

\section{K.L. Arnold is UC Cooperative Extension (UCCE) Orchard and} Vineyard Systems Advisor, Stanislaus County; N. McRoberts is Associate Professor of Plant Pathology, Quantitative Biology and Epidemiology Lab, Plant Pathology Department, UC Davis; M.L. Cooper is UCCE Viticulture Farm Advisor, Napa County; R. Smith is UCCE Viticulture Farm Advisor, Sonoma County; and D.A. Golino is Director of Foundation Plant Services, Foundation Plant Services and Plant Pathology Department, UC Davis.

This project was supported by the American Vineyard Foundation. We acknowledge the invaluable assistance of the staff, students and faculty at Foundation Plant Services, UC Davis, and the laboratory guidance of Vicki Klaassen. Additionally, we want to thank the North Coast wine grape growers for providing access to their vineyards.

\section{References}

Al Rwahnih M, Daubert S, Golino D, et al. 2015. Comparison of next-generation sequencing versus biological indexing for the optimal detection of viral pathogens in grapevine. Phytopathology 105(6):758-63.

Al Rwahnih M, Dave A, Anderson MM, et al. 2013. Association of a DNA virus with grapevines affected by red blotch disease in California. Phytopathology 103(10):1069-76.

Al Rwahnih M, Golino D, Rowhani A. 2016. First report of Grapevine Pinot gris virus infecting grapevine in the United States. Plant Dis 100(5):1030.

Al Rwahnih M, Rowhani A Golino DA. 2015. First report of Grapevine red blotch-associated virus in archival grapevine material from Sonoma County, California. Plant Dis 99(6):895.

Alley L, Golino D. 2000. The origins of the grape program at Foundation Plant Materials Service. In: Proc Am Soc Enol Viticult 50th Anniv Mtg, Jun 19-23, 2000. Seattle, Washington. p 222-30.
Arnold KL, Golino DA, McRoberts N. 2017. A synoptic analysis of the temporal and spatia aspects of grapevine leafroll disease in an historic Napa vineyard and experimental vine blocks. Phytopathology 107(4):418-26.

Bahder BW, Zalom F, Jayanth M Sudarshana MR. 2016. Phylogeny of geminivirus coat protein sequences and digital PCR aid in identifying Spissistilus festinus (Say) as a vector of Grapevine red blotch-associated virus. Phytopathology 106(10):1223-30.

Fuller KB, Alston JM, Golino DA. 2015. The economic benefits from virus-screening: A case study of grapevine leafroll in the north coast of California. Am J Enol Viticult 66(2):112-20.

Goheen A, Cook JA. 1959. Leafroll (red-leaf or rougeau) and its effects on vine growth, fruit quality, and yields. Am J Enol Viticult 10(4):173-81.
Golino DA, Fuchs M, Sim S, et al. 2017. Improvement of grapevine planting stock through sanitary selection and pathogen elimination. In: Meng B, Martelli GP, Golino DA, Fuchs M (eds.) Grapevine Viruses: Molecular Biology, Diagnostics, and Management. Springer. p 561-80.

Golino D, Sim S, Gill R, Rowhani A. 2002. California mealybugs can spread grapevine leafrol disease. Calif Agr 56(6):196-201. https://doi.org/10.3733/ ca.v056n06p196

Hughes G, Madden L. 1992. Aggregation and incidence of dis ease. Plant Pathol 41(6):657-60. Hughes G, Madden L. 1993 Using the beta-binomial distribution to describe aggregated patterns of disease incidence. Phytopathology 83(7):759-63.

Klaassen VA, Sim ST, Dangl G, et al. 2011. Vitis californica and Vitis californica $\times$ Vitis vinifera hybrids are hosts for Grapevine leafrollassociated virus- 2 and -3 and Grapevine virus A and B. Plant Dis 95(6):657-65.
Madden LV, Hughes G, Bosch F. 2007. The Study of Plant Disease Epidemics. St. Paul, MN: APS Press.

Martelli G. 2014. Directory of virus-like diseases of the grapevine and their agents. J Plant Pathol 96(suppl. 1):1-136.

McRoberts N, Hughes G, Madden L. 2003. The theoretical basis and practical application of relationships between different disease intensity measurements in plants. Ann Appl Biol 142(2):191-211.

Olmo HP. 1951. A proposed program for the introduction, improvement and certification of healthy grape varieties. Wines \& Vines 32(7):7-9.

Raski D, Hewitt WB. 1960. Experiments with Xiphinema index as a vector of fanleaf of grapevines. Nematologica 5(3):166-70.

Ricketts KD, Gomez MI, Atallah SS, et al. 2015. Reducing the economic impact of grapevine leafroll disease in California: Identifying optimal disease management strategies. Am J Enol Viticult 66(2):138-47.
Ricketts KD, Gómez MI, Fuchs MF, et al. 2017. Mitigating the economic impact of grapevine red blotch: Optimizing disease management strategies in U.S. vineyards. Am J Enol Viticult 68(1):127-35

Rowhani A, Uyemoto JK, Golino DA, Martelli GP. 2005. Pathogen testing and certification of Vitis and Prunus species. Annu Rev Phytopathol (43):261-78.

Syller J. 2012. Facilitative and antagonistic interactions between plant viruses in mixed infections. Mol Plant Pathol 13(2):204-16

Tsai C-W, Chau J, Fernandez $\mathrm{L}$, et al. 2008. Transmission of Grapevine leafroll-associated virus 3 by the vine mealybug (Planococcus ficus). Phytopathology 98(10):1093-8.

Weber E, Golino D, Rowhani A. 2002. Laboratory testing for grapevine diseases. Prac Winery Vineyard J Jan/Feb:1-5.

Wolpert J, Walker A, Weber E, et al. 1994. Rootstocks and phylloxera: A status report for coastal and northern California. Viticult Notes (6):1-17. 


\section{UNIVERSITY OF CALIFORNIA Agriculture and Natural Resources}

\section{California Agriculture}

2801 Second Street

Room 181A

Davis, CA 95618-7779

Phone: (530) 750-1223

Fax: (530) 756-1079

Visit us online:

calag.ucanr.edu

twitter3 @Cal_Ag

www.facebook.com/CaliforniaAgriculture

\section{Upcoming UC and UC ANR events}

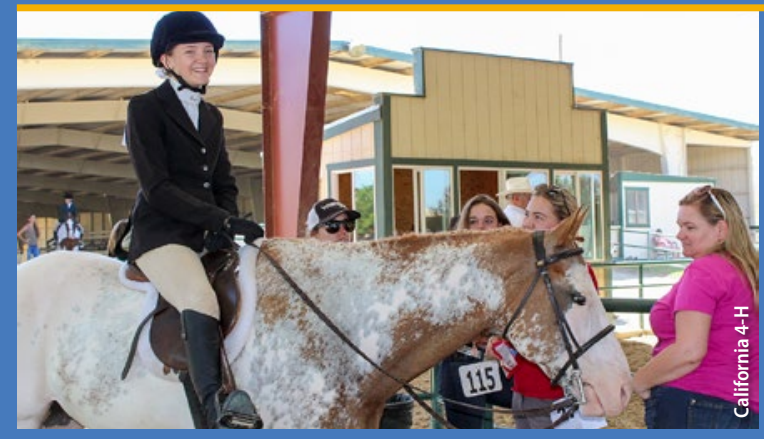

\section{California 4-H State Horse Classic}

http://4h.ucanr.edu/4-H_Events/Horse_Classic/

Date: June 27-30, 2019

Time: All day

Location: Elk Grove

Contact: Shauna Bond sabond@ucanr.edu or 530-260-3277

Weed Day 2019 - UC Davis Department of Plant Sciences https://wric.ucdavis.edu/events/weed_day_2019.html

Date: July 11, 2019

Time: All day

Location: Walter A. Buehler Alumni Center, UC Davis

Contact:wric@ucdavis.edu or 530-752-1748
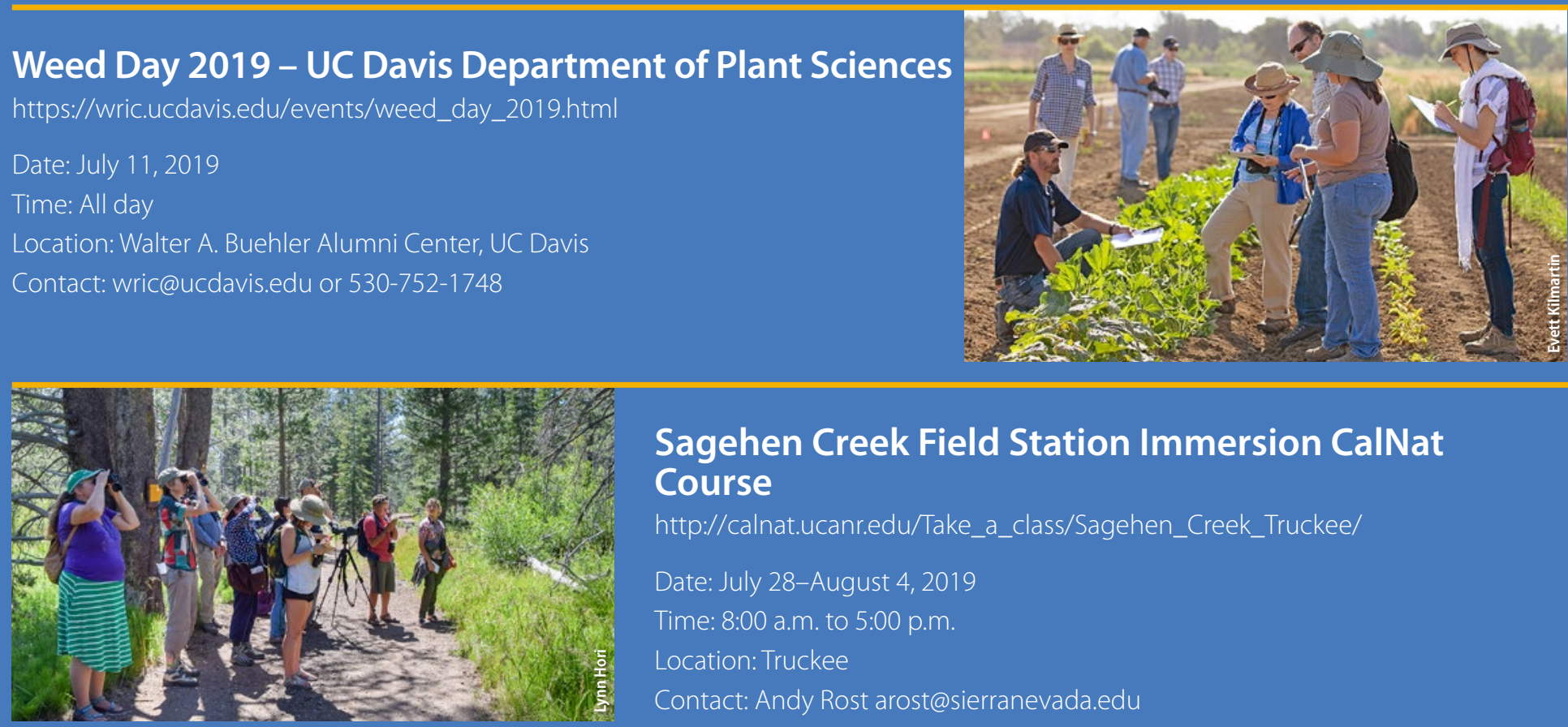

Sagehen Creek Field Station Immersion CalNat Course

http://calnat.ucanr.edu/Take_a_class/Sagehen_Creek_Truckee/

Date: July 28-August 4, 2019

Time: 8:00 a.m. to 5:00 p.m.

Location:Truckee

Contact: Andy Rost arost@sierranevada.edu 